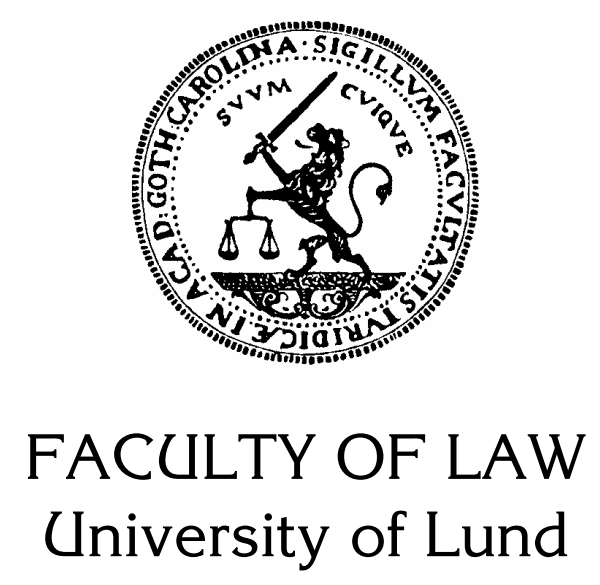

Author: Md. Mahboob Murshed

\title{
Title: Curbing Software Piracy in eCommerce: Compatibility with Human Rights: Challenges and Possible Solutions
}

\author{
Master thesis \\ 20 points \\ Semester: $3^{\text {rd }}$ \\ Lund, Sweden \\ August 2004
}

Supervisor : Mpazi Sinjela

Field of study: Copyright $\mathcal{E}$ Industrial Property Law 


\section{Contents}

SUMMARY

$\begin{array}{ll}\text { DEDICATION } & 7\end{array}$

$\begin{array}{ll}\text { PREFACE } & 8\end{array}$

$\begin{array}{ll}\text { ABBREVIATIONS } & 10\end{array}$

1 INTRODUCTION 11

$\begin{array}{ll}\text { 1.1Prelude } & 11\end{array}$

1.2 Software and eCommerce 12

$\begin{array}{ll}\text { 1.3 Role of Software in eCommerce } & 14\end{array}$

1.4 Software Infringements in eCommerce

$\begin{array}{ll}\text { i. Softlifting } & 15\end{array}$

ii. Unrestricted Client Access 15

iii. Commercial Use of Non commercial Software 16

iv. Internet Piracy 16

$\begin{array}{ll}1.5 \text { Gravity and Consequence of Software Piracy in eCommerce } & 17\end{array}$

1.6 Permitted Actions in Relation to the Software 18

$\begin{array}{lll}\text { 1.7 Jurisdiction, Choice of Law and Enforcement } & \text { Issues }\end{array}$

2. INTERNET PIRACY: A GRAVE CHALLENGE 23

2.1. Forms of Internet Piracy 23

2.2. How Internet Piracy Occurs 26

2.3. Analysis of Important Cases on Internet Piracy 27

3 SOFTWARE PATENTING VIS-À-VIS COPYRIGHT 36

3.1A Brief History of Software Patenting 36

3.2 Laws Relating to Software Patenting $\quad 38$

3.2.1 TRIPS Agreement 38

3.2.2 The US Law $\quad 40$

3.2.4 European Law 46

$\begin{array}{ll}\text { 3.3 Software Patent V. Copyright } & 50\end{array}$ 
4.2 European Legal Framework 58

4.2.1 E.C. Software Directive 58

4.2.2. Copyright Directive $\quad 59$

4.2.3.

E-Commerce Directive $\quad 59$

4.2.4 Legal Framework of U.K. $\quad 60$

4.3. Legal Framework of the United States 63

4.4.Difference Between UK and US Law 69

4.5 International Standard Setting $\quad 71$

5 TECHNOLOGICAL PROTECTION MEASURES 72

5.1. Technological enforcement in Australia 73

5.2The Present Legal Framework for Technological Enforcement $\quad 74$

5.2.1 WIPO Copyright Treaty 74

5.2.2 United States of America $\quad 75$

5.2.2.1. Limitations and Exceptions of DMCA 76

5.2.2.2. US Case Laws on Ante-Circumvention Provisions 77

5.2.3 European Union on Technological Enforcement 78

5.2.3.1 Limitations and Exceptions Provided in the EU Directives 80

$\begin{array}{ll}\text { 5.2.3.2 Rights -Management Information } & 81\end{array}$

5.3 Implementation of DRM

6 COMPATIBILITY WITH HUMAN RIGHTS 83

6.1. Brief Introduction to the Interface $\quad 83$

6.2 Human Rights and International IP Treaties $\quad 86$

6.3 Human Rights and Copyrights $\quad 90$

6.3.1 International Copyright Laws 90

6.3.2 National Jurisdictions $\quad 94$

6.3.2.1 U.S.A.

(1) the purpose and character of the use, including whether such use is of a commercial nature or is for nonprofit educational purposes; $\quad 94$

(2) the nature of the copyrighted work; 94

(3) the amount and substantiality of the portion used in relation to the copyrighted work as a whole; and 94

(4) the effect of the use upon the potential market for or value of the copyrighted work. 
6.3.2.2 United Kingdom

6.4 Human Rights and Software Patenting 100

6.5 Scope of Getting Right Balance 101

6.6 Human Rights Approach in Curbing Measures 103

7 CONCLUSION AND RECOMMENDATIONS 106

BIBLIOGRAPHY

TABLE OF CASES 


\section{Summary}

Software and eCommerce are inseparable part of each other. The main thrust of the thesis is to discover a suitable legal and technological measures for curbing software in eCommerce and find out compatibility of the existing curbing measures with human rights. The WIPO Copyright treaty, the Berne Convention, the TRIPS Agreement and other international laws on copyright, patent and software have been discussed in relevant places. Information and statements from the papers prepared by WIPO on digital right management, eCommerce, and copyright have been frequently used in the thesis with proper citation. Since the U.S.A is the pioneer in the software industry and eCommerce therefore particular attention has been given on the U.S. legal system. A considerable number of relevant cases from the U.S. jurisdiction have been discussed in relevant chapters of the thesis. The European law and British law also have been discussed with limited number of case references. Since Bangladesh is a developing country; the relevant copyright law of Bangladesh and its prospect in software industry also has been discussed briefly. The thesis is divided in 7 chapters. A summary of each chapter has been given below.

Chapter 1: Introduction: It contains a brief introduction of the issues discussed in the thesis and explanations regarding software, eCommerce, kinds of software infringements, gravity and consequence of software piracy in eCommerce, permitted actions in respect of software, jurisdiction, choice of law and enforcement issues etc.

Chapter 2: Internet Piracy a Grave Challenge: In this chapter how Internet piracy of software takes place is explained with example and case reference from the U.S. jurisdiction.

Chapter 3: Software Patenting vis-à-vis Copyright: A comparative discussion between software patenting and copyright protection for software takes place in this chapter.

The relevant laws of the U.S. jurisdiction and European jurisdiction have been discussed with important case references of the respective jurisdiction. It is also discussed whether these two types of protection for software are conflicting or complementary.

Chapter 4: Regulatory Framework for Curbing Piracy: In this chapter basically copyright law relating to software has been discussed. Relevant provisions regarding software from international copyright Law like the Berne Convention, WIPO Copyright Treaty, and TRIPS Agreement have been cited. EC Software Directive, Copyright Directive and eCommerce Directive, Statutory law and case law of the U.S. jurisdiction, the UK jurisdiction have been discussed here.

Chapter 5: Technological Protection Measures: Technological protection measure in Australia, anti circumvention provision in WIPO Copyright Treaty, Digital Millennium Copyright Act (DMCA) of the U.S.A., Limitations and exceptions of DMCA, EC Copyright Directive and limitations and exceptions of the Copyright Directive, Rights management information etc. have been discussed. 
Chapter 6: Compatible Human Rights: What are the bases of the relationship between IPR and human rights, which provisions of the relevant international IP law and different national jurisdictions are upholding human rights have been discussed here. Relevant case law has been cited from the U.S. jurisdiction to show that the court did not find the anti circumvention provisions of the DMCA unconstitutional and opposed to the right to freedom of expression. It has been shown in this chapter that there is no real conflict between human rights like freedom of expression and curbing measures of software piracy in eCommerce.

Chapter 7: Conclusion and Recommendations: Concluding comments and Specific recommendations have been given to curb software piracy in eCommerce and develop human rights values in IPR protection. 


\section{Dedication}

Dedicated to my parents Ms. Rehana Hussain and Mr. Mosharaf Hussain 


\section{Preface}

The essence of that classic maxim of common law, "a right without a remedy is no right at all," is equally applicable to the curbing software piracy in eCommerce. If software owners cannot protect the software in eCommerce environment then the potential IPRs subsist in their software would be valueless. Software is the foundation of eCommerce upon which entire eCommerce subsists. Software piracy affects adversely the growth of software industry and obstructs the rapid expansion of eCommerce. The Business Software Alliance in its 2004 software piracy study report mentioned that for every two dollars' worth of software purchased legitimately, one dollar's worth was obtained illegally. The piracy rate - the number of pirated software units divided by the total number of units put into use - was 36 percent in 2003. Therefore, curbing software piracy in eCommerce is extremely important.

The main issue is how we can curb piracy. Intellectual property law particularly copyrights law and patent law can be substantially used in curbing piracy. Beside this we can use the digital rights management or technical measures with necessary legal protection, which may be in many cases, would be more effective than legal measures. These measures have been elaborately discussed in this thesis. The compatibility of the curbing measures with human rights has been discussed in a limited way. It has been shown in the thesis that there is no apparent conflict between the curbing measures of software piracy and human rights like right to freedom of expression. Moreover curbing software piracy is favourable to the development of the software industry and eCommerce. Such development would contribute to the growth of per capita GDP. In other words we can say curbing software piracy will be helpful to achieve the right to development. Apart from these issues the thesis also deals with the liability of intermediaries service providers on the Internet for software infringement. Specific recommendations have been suggested to curb software piracy in eCommerce and to make the curbing measures more human rights compatible.

The area chosen for the thesis is comparatively less explored than other fields of IP and human rights law. The application and enforcement of IP law in eCommerce environment involve a lot of complicated issues. Compatibility of IP law with human rights makes the topic more complicated. The human rights issues in software infringements and protection measures of software in eCommerce have not yet been adequately addressed in case laws of the developed countries like the U.S.A., U.K., Canada, Australia, Japan etc. Instead of these constraints various important issues like different kinds of the Internet software piracy, the effectiveness of software patenting, legal framework to curb piracy, technical measures have been addressed in this thesis with human rights issues.

In writing the thesis I have received scholarly guidance from my Supervisor Mr. Mpazi Sinjela, who despite of his busy schedule gave me his valuable suggestions and necessary ideas to develop the thesis. I express my heart-felt gratitude to him. I must convey my thanks to Professor Gudmundur Alfredsson, who has kindly consented to take my defense of the thesis. I would also like to convey my thanks 
to Ms. Lena Olsson and Mr. Habteab Testay for giving me necessary library support.

On this occasion of defense I must remember the contribution of my elder brother Captain Monzoor Murshed, to whom I would like to be indebted through out my life.

I express my gratitude to my aunt Sahera Rahman, to my uncle Mr. A. Hafij Chowdhury, to my cousin Mr. Golam Rahman who helped me materially to pursue the study.

My wife. Shamsuna Borat Chowdhury, my sons Rafid Umayer Murshed and Sadid Jubayer Murshed suffered the pain of my long absence and encouraged me to pursue the study. I must remember their sacrifice from the core of my heart.

I would like to convey my thanks to the teaching staffs, administrative staffs and my fellow students of the Lund University and RWI for a congenial academic atmosphere and good time in Lund.

If this thesis can contribute a little in the present battle of curbing software piracy in eCommerce then I would find the justification of my effort.

Lund, Sweden

31 August 2004

Md. Mahboob Murshed

Raoul Wallenberg Institute

of Human Rights and Humanitarian Law

Lund University 


\section{Abbreviations}

$\begin{array}{ll}\text { CADA } & \text { Copyright Amendment (Digital Agenda) Act 2000, } \\ \text { CDPA } & \text { Australia } \\ \text { CPPA } & \text { Copyright, Designs and Patents Act 1988, United Kingdom } \\ \text { CSM } & \text { Certified Software Manager } \\ \text { CSS } & \text { Content Scramble System } \\ \text { DeCss } & \text { Decryption Content Scramble System } \\ \text { DRMs } & \text { Digital Rights Managements } \\ \text { DVDs } & \text { Digital Versatile Disks } \\ \text { eCommerce } & \text { Electronic Commerce } \\ \text { EPC } & \text { European Patent Convention 1973 } \\ \text { SIIA } & \text { Software and Information Industry Association } \\ \text { FTP } & \text { File Transfer Protocols } \\ \text { GIIC } & \text { Global Information Infrastructure Commission } \\ \text { HTML } & \text { Hypertext Markup Language } \\ \text { ICCPR } & \text { International Covenant on Civil and Political Rights } \\ \text { ICESCR } & \text { International Covenant on Economic, Social and Cultural } \\ & \text { Rights } \\ \text { IRC } & \text { Internet Relay Chat } \\ \text { ISP } & \text { Internet Service Provider } \\ \text { OHCHR } & \text { Office of the United Nations High Commissioner for } \\ & \text { Human Rights } \\ \text { P2P } & \text { Peer-to-Peer } \\ \text { TRIPS Agreement } & \text { Agreement on Trade Related Aspects of Intellectual } \\ & \text { Property Rights (1994) } \\ \text { UDHR } & \text { Universal Declaration of Human Rights 1948 } \\ \text { UNDP } & \text { United Nations Development Programme } \\ \text { UNEP } & \text { United Nations Environment Programme } \\ \text { URL } & \text { Uniform Resource Locator } \\ \text { USPTO } & \text { United States Patent and Trademark Office } \\ \text { USTR } & \text { United States Trade Representative } \\ \text { WCT } & \text { WIPO Copyright Treaty (1996) } \\ \text { WHO } & \text { World Health Organization } \\ \text { WIPO } & \text { World Intellectual Property Organization } \\ \text { WPPT } & \text { WIPO Performances and Phonograms Treaty (1996) } \\ \text { WTO } & \text { World Trade Organization } \\ & \end{array}$




\section{Introduction}

\subsection{Prelude}

Software is one of the few intangible products, which can be sold and delivered on line. The heart and soul of the digital revolution is computer software. But software piracy can undermine the sound growth of the flourishing software industry. Online software piracy or software piracy in eCommerce could take place very easily through out the world within the shortest possible time. Therefore, the volume of loss occurred due to software piracy in eCommerce is tremendous. Since software involves a substantial issue of intellectual property rights and intellectual property law plays a vital role in the protection of software in eCommerce, that's why the issue is one of the most burning issues in intellectual property law. There are two primary ways to combat online piracy: technical protection measures and regulatory frameworks. Both approaches are elaborately discussed in the forthcoming chapters.

Recently a movement started in the initiative of the World Intellectual Property Organization in collaboration with the Sub-Commission on the Promotion and Protection of Human Rights to find out the relationship between the intellectual property rights and human rights. Therefore besides dealing with curbing measures of software piracy in eCommerce there will be an initiative to find out compatibility of curbing measures with human rights. In this thesis among others, the specifically following issues will be addressed:

i. How does software piracy take place in eCommerce?

ii. Which protection is better for software: patent or copyright?

iii. What is the legal framework to curb software piracy in eCommerce?

iv. What is the technological framework to curb software piracy in eCommerce?

v. What are the bases of the relationship between software protection measures in IP Law and human rights?

vi. What measures can be taken to strengthen the protection of software in eCommerce?

Since copyright directly protects software in eCommerce, therefore, particular emphasis will be given in discussing copyright law in this regard. The United States is the pioneer in Internet technology and possesses the world's biggest software industry. Due to this advantageous position of the U.S.A. software related laws and case law have considerably been developed there. That is why particular emphasis has been given in discussing U.S. laws and case laws in the relevant chapters. Relevant European law, British law and case law also have been discussed with due importance. In one occasion an Australian example has been cited while discussing technological enforcement of copyright. The law of Bangladesh also has been mentioned in dealing with the compatibility of IPRs with human rights. Some basic terminologies like software, eCommerce, and software infringements have been explained in this Chapter. 


\subsection{Software and eCommerce}

Software includes computer programs, databases, preparatory material and associated documentation (in printed or electronic form) such as manuals for users of the programs and for persons who have to maintain the programs. It can also include all manner of other works stored in digital form, interfaces (for example, with the user of hardware or other software), programming languages and software tools to be used to develop software systems ${ }^{1}$. A computer program is a series of instructions by which desired output can be achieved from the computer. Under the Computer Program Protection Act (CPPA), a computer program is defined as a work expressed in the form of a series of instructions or orders that are used directly or indirectly to obtain a specific result in a computer or other device having information-processing capability ${ }^{2}$. Digitised material can be used as a program to drive the electronic hardware of the computer itself. This is the case both for applications programs for word processing, product design and many other things ${ }^{3}$. The finished code of a computer program is the culmination of a long process involving the creation of a number of preparatory (and intermediate) works. For example, the analysts and programmers working on the development of a new program usually will produce specifications, flowcharts, diagrams, layouts for menus, screen displays and reports and other materials ${ }^{4}$. Generally protection is provided to programs that are considered to be creative in expressions. But in Japan the elements of the program that are considered as a means to create the expression are also protected ${ }^{5}$. In United States program languages, syntax, rules and algorithms (which are used for arraigning programs) are not protected because they are considered as a means to create an expression rather than a form of expression ${ }^{6}$.

We need not look back to the remote past to see the beginning of the eCommerce transaction. In 1986, the first company operating a commercial service on the Internet was a stamp exchange, called the "International Stamp Exchange." The "electronic commerce" part of the stamp company was performed through telex terminals or personal computers. In 1996 the term eCommerce, appeared. 1998 is

\footnotetext{
${ }^{1}$ See D Bainbridge, Intellectual Property, P199, Fourth Edition, Financial Times Pitman Publishing.

2 See Joon Kook Park, “Asian Protection Strategies for the Internet” PP. 274-275, Intellectual Property for the Internet, Edited by LC Lee and JS Davidson, A Panel Publication (1997).

${ }^{3}$ See W Cornish and D Llewelyn, Intellectual Property: Patents, Copyright, Trademarks and Allied Rights, p. 761, Fifth Edition, Sweet \& Maxwell, 2003.

${ }^{4}$ See D Bainbridge, Intellectual Property, P.203, Fourth Edition, Financial Times Pitman Publishing.

5 See Id P. 203.

${ }^{6}$ See Joon Kook Park, “Asian Protection Strategies for the Internet” P-275, Intellectual Property for the Internet, Edited by LC Lee and JS Davidson, A Panel Publication (1997).

${ }^{6}$ See W Cornish and D Llewelyn, Intellectual Property: Patents, Copyright, Trademarks and Allied Rights, p. 761, Fifth Edition, Sweet \& Maxwell, 2003.
} 
regarded by many as the year eCommerce really began, leading to today's wide consumer adoption of eCommerce. A recent report by the research firm, Jupiter, estimated that online retail spending in the U.S.A. would increase by $28 \%$ in 2003 to US $\$ 52$ billion. Jupiter also estimates that by 2007 online retail spending could reach US $\$ 105$ billion and represent about $5 \%$ of the U.S.A. retail spending. Online retail spending is also booming in Europe ${ }^{7}$.

The term "electronic commerce" is understood to mean the production, distribution, marketing, sale or delivery of goods and services by electronic means ${ }^{8}$. The term electronic commerce has been defined as follows: "Electronic commerce, or e-commerce, is a term that has become synonymous with commercial transactions involving both organisations and individuals, based upon the processing and transmission of digitised data, including text, sound, and visual images, transmitted over open networks such as the internet." ".

The term "electronic commerce" has, in just the last few years, achieved widespread recognition, becoming a highly visible symbol in the contemporary language of the information technology culture that brought profound changes in the final years of the last millennium. The words are commonly used in the media, in business, and in casual conversation to refer to a broad class of activities, which we generally understand to be associated with the use of a computer and the Internet to trade goods and services in a new, direct and electronic manner ${ }^{10}$.

Electronic commerce can be divided into three stages: first, the pre-purchase stage including advertising and information seeking; second, the purchase stage, including purchase and payment; and third, the delivery stage. In principle, all types of products can be advertised and purchased over electronic networks. The potential for electronic delivery, however, is more limited. It requires that a final product can be presented as digitalized information and transmitted electronically, typically over the Internet. Many services can be supplied as digitalized information, including financial transactions or legal advice. Some information and entertainment products typically characterized as goods, such as books, software, music and videos embody digitalized information that can also be supplied electronically over the Internet ${ }^{11}$.

The Global Information Infrastructure Commission in its policy paper "GIIC Recommendations for Promoting the Use of Electronic Commerce",12 stated that

\footnotetext{
${ }^{7}$ See Mr Jeffrey P et al, Current Development in the Field of Digital Rights Management, P. 6, Standing Committee on Copyright And Related Rights, Tenth Sessions, WIPO, SCCR/10/2, August 1, 2003.

${ }^{8}$ See Work programme on Electronic Commerce-Adopted by the General Council on 25 September 1998-WTO. WTO Trade Topics - Electronic commerce - Work programme on electronic commerce.htm

${ }^{9}$ See James Catchpole: The Regulation of Electronic Commerce: A Comparative Analysis of the Issues Surrounding the Principles of Establishment, International Journal of Law and Information Technology, Vol. 9 No. 1, Oxford University Press 2001.

${ }^{10}$ See Primer on Electronic Commerce and Intellectual Property Issues, WIPO, May 2000, http://ecommerce,wipo.int

${ }^{11}$ See Staff Working Paper ERAD-99-01, September, 1999, World trade organization.

${ }^{12}$ See www.giic.org/papers/policy/ecrecs.ap, last visited 8 June 2004.
} 
Electronic commerce is any use of electronic networks and technology for commerce and other economic activity. This includes the use of electronic communication as the medium through which goods and services of economic value are designed, produced, advertised, catalogued and inventoried, purchased and accounts settled. Geographic location, abundance of capital or the ownership of retail outlets is irrelevant to this type of transaction. Private and public enterprises, citizens, companies, entrepreneurs, public institutions and government organizations, all types of social organizations and corporations will be able to freely participate in economic activities over a wide range of sectors including agriculture, forestry and fishery, industry, private and government services. Electronic commerce will allow products to be marketed worldwide, while providing a wide array of options to the consumer.

Electronic commerce (e-commerce) is any transaction completed over a computer-mediated network that involves the transfer of ownership or rights to use goods or services. Computer-mediated networks are electronically linked devices that communicate interactively over network channels ${ }^{13}$.

\subsection{Role of Software in eCommerce}

WIPO in its paper "Intellectual Property A Power Tool for Economic growth" mentioned computer software as the heart and soul of the Digital Revolution. It further opined that the computer software industry is huge. It touches literally everything which is digital. It is the only industry, which has never had to cope with the impact of the digital revolution, since it is the only industry, which commenced its business in digital format; and it has served as the basis for the creation of more new wealth than at any other time in history. Software and computers are inextricably tied together. Computers were created during the 1940s, and at first went through a slow evolution. Things took a quantum leap forward in 1976, when Apple Computer developed a powerful personal computer, which allowed ordinary people to bring unprecedented computing power into the private home. Fro $m$ the point of the introduction of the PC in 1981, not a day has gone by without some new development, advance, or break through in this industry: computing power and capabilities, data storage and management, and telecommunications - but it is computer software which is fundamental in most of these advances ${ }^{14}$.

Over the past several years, advances in computer software have brought us timesaving business programs, educational software that teaches basic skills and sophisticated subjects, graphics programs that have revolutionized the design industry, Internet applications that help connect us with other computer users, and an increasingly complex variety of computer games to entertain us. As the software industry grows, everyone stands to benefit.

\footnotetext{
${ }^{13}$ See "Measuring Electronic Business Definitions, Underlying Concepts, and Measurements Plans," Government of the United States of America (October 13, 1999) at http://www.ecommerce.gov/ecomnews/e-def.html.

${ }^{14}$ See Intellectual Property A Power Tool for Economic Growth, PP. 208-210, at www.wipo.int/about/wipo/en/dgo/wipo_pub_888/index_wipo_pub888.html, last visited 8 June 2004.
} 
How software is important as an intangible property in e-commerce can be realised from the following statement:

"[the] Internet facilitates both commerce in physical products and commerce in intangible products. For commerce involving physical products, the Internet functions as a global system facilitating sales, in which the placing of an order and the making of payment can (but does not necessarily have to) take place online, while the goods themselves are delivered separately through a postal or other delivery service. For commerce involving intangible products, the Internet serves not only as a system to promote sales, but also as a system to effectuate the delivery of the intangible product itself, such as a piece of music or software, a film or a publication. This distribution can take place almost instantaneously, and the intangible product may travel virtually without restriction across national borders. Indeed, this aspect of electronic commerce may be its most compelling dimension: there is an inherent logic to using the Internet to buy and sell intangible products that need never be more than digital "bits." At the same time, however, there is a commensurate need for effective intellectual property protection that can address the international dimensions of this commerce"

The significance of software product in e-commerce is that it can be easily transacted through Internet. Advertisement, sale and delivery of software products can be made online. Moreover to develop e-commerce and the Internet system software plays a significant role. World Wide Web, HTTP, HTML, hyperlink, metatag and all necessary aspects of Internet depends on software.

\subsection{Software Infringements in eCommerce}

Software infringements can take place in several ways in eCommerce. The Software and Information Industry Association (SIIA) has summed up the most popular types of software piracy as follows ${ }^{16}$ :

\section{i. Softlifting}

Softlifting takes place when a person purchases a single licensed copy of a software program and loads it on several machines, in violation of the terms of the license agreement. Typical examples of softlifting include, "sharing" software with friends and co-workers and installing software on home/laptop computers if not allowed to do so by the license. In the corporate environment, softlifting is the most prevalent type of software piracy - and perhaps, the easiest to catch. Softlifting is one of the ways of infringing software in eCommerce.

\section{ii. Unrestricted Client Access}

Unrestricted client access piracy takes place when a copy of a software program is copied onto an organization's servers and the organization's network "clients"

${ }^{15}$ See WIPO, Primer on Electronic Commerce and Intellectual Property Issues, PP.4-5, available at ecommerce.wipo.int/primer, last visited 4 July 2004.

\footnotetext{
${ }^{16}$ See at www.siia.net, last visited 4 July 2004.
} 
are allowed to freely access the software in violation of the terms of the license agreement. This is a violation when the organization has a "single instance" license that permits installation of the software onto a single computer, rather than a client-server license that allows concurrent server-based network access to the software. A violation also occurs when the organization has a client-server license, the organization is not enforcing user restrictions outlined in the license. For instance, when the license places a restriction on the number of concurrent users that are allowed access to that program and the organization is not enforcing that number. Unrestricted client access piracy is similar to softlifting, in that it results in more employees having access to a particular program than is permitted under the license for that software. Unlike softlifting though, unrestricted client access piracy occurs when the software is loaded onto a company's server - not on individual machines - and clients are permitted to access the server-based software application through the organization's network. Unrestricted Client Access is also another method of infringing software in eCommerce.

\section{iii. Commercial Use of Non commercial Software}

Using educational or other commercial-use-restricted software in violation of the software license is a form of software piracy. Software companies will often market special non-commercial software aimed at a particular audience. For example, many software companies sell educational versions of their software to public schools, universities and other educational institutions. The price of this software is often greatly reduced by the publisher in recognition of the educational nature of the institutions. Acquiring and using non-commercial software hurts not only the software publisher, but also the institution that was the intended recipient of the software. This kind of software piracy can be taken place through the Internet and is a threat to eCommerce as well as copyright owners.

\section{iv. Internet Piracy}

Internet piracy is the uploading of commercial software (i.e., software that is not freeware or in the public domain) on to the Internet for anyone to copy or copying commercial software from any of the services like auction site, FTP site, IRC chat-rooms, warez site or redistributed via e-mail. Internet piracy also includes making available or offering for sale pirated software over the Internet. Examples of this include the offering of software through an auction site, IM, IRC or a warez site. Incidences of Internet piracy have risen exponentially over the last few years. Since the Internet piracy is a serious and complicated challenge before the software industry, therefore the topic would be treated in details in the following chapter. 


\subsection{Gravity and Consequence of Software Piracy in eCommerce}

On average, the software industry loses about US\$11 to US\$12 billion in revenue to software piracy annually. Of the billions of dollars lost to piracy, a little less than half comes from Asia, where China and Indonesia are the biggest offenders. Piracy is also a big problem in Western Europe, where piracy losses annually range from $\$ 2.5$ and $\$ 3$ billion dollars. Piracy rates are quite high in Latin America and in Central Europe, but their software markets are so much smaller that the dollar losses are considerably lower ${ }^{17}$.

About $\$ 2$ billion in piracy losses come from North America. The piracy rate in the United States has been relatively constant at about $25 \%$ over the past few years, which is the lowest rate of any country. This means that one in every four copies of business application software is used illegally. The large dollar amount in losses is attributable more to the fact that there are so many computers and computer users in the United States than to a high piracy rate when compared with the rest of the world ${ }^{18}$.

The losses suffered through software piracy directly affect the profitability of the software industry. Because of the money lost to pirates, publishers have fewer resources to devote to research and development of new products, have less revenue to justify lowering software prices and are forced to pass these costs on to their customers. Consequently, software publishers, developers, and vendors are taking serious actions to protect their revenues.

Using pirated software is also risky for users. Aside from the legal consequences of using pirated software, an organization forfeits some practical benefits as well. Those who use pirate software:

Increase the chances that the software will not function correctly or will fail completely;

Forfeit access to customer support, upgrades, technical documentation, training, and bug fixes;

Have no warranty to protect themselves;

Increase their risk of exposure to a debilitating virus that can destroy valuable data;

May find that the software is actually an outdated version, a beta (test) version, or a nonfunctioning copy;

Are subject to significant fines for copyright infringement; and

Risk potential negative publicity and public and private embarrassment (once caught).

\footnotetext{
${ }^{17}$ See at www.siia.net, last visited 4 July 2004.

${ }^{18}$ See at www.siia.net, last visited 4 July 2004.
} 
The numerous ways in which software piracy occurs, the ease of duplication and the high quality of pirated software present a significant problem to the software industry. Unlike analogue products subject to illegal copying, such as audiotapes and videotapes, there is no degradation in the quality of software from copy to copy. A program that reflects unprecedented technology, years of effort and millions of development dollars can be duplicated or illegally distributed in minutes with the touch of a button. Any PC user can duplicate a product priced from $\$ 20$ to $\$ 20,000$ for no more than the cost of a blank CD or at no cost, and that user can make one, a dozen or a thousand functional copies. The unauthorized copying of personal computer software for use in the office or at home or "sharing" of software among friends and co-workers is the most pervasive form of piracy encountered and is estimated to be responsible for more than half the total revenues lost by the industry.

It is also worth noting that the use of pirated software also drives up the costs for legitimate users - which gives legitimate users all the more reason to help association like SIIA fight piracy by reporting those companies that are not "playing by the rules."

\subsection{Permitted Actions in Relation to the Software}

Of course, where there are rules there are exceptions. As the copyright law developed in the physical world, so did its corresponding exceptions. These exceptions also apply in the digital environment. In some circumstances, however, the exceptions in the digital environment threaten to swallow the rule and remove copyright protection all together. There are several exceptions to the copyright owner's exclusive rights scattered throughout the Copyright Act. The most significant one is the doctrine of fair use, which permits someone to use a work without the copyright owner's permission and without payment for such use in certain circumstances. There is no bright-line test for determining when a particular use constitutes a fair use under the law. It is determined on a case-bycase basis and depends on balancing the following factors: (1) the purpose and character of the use, including whether the use is commercial or for nonprofit educational purposes; (2) the nature of the copyrighted work; (3) the size of the portion used in relation to the copyrighted work as a whole; and (4) the effect of the use on the potential market for or value of the copyrighted work.

In addition to the fair use exception, there are other exceptions and limitations to the copyright owner's exclusive rights in the Copyright $\mathrm{Act}^{19}$. For example, these include exceptions that allow:

….. Libraries and archives to make copies for preservation purposes.

…. The purchaser of a computer program to make a copy of that

program for archival or backup purposes.

..... Certain performances and displays for the purposes of

classroom education, religious services, and transmissions to

disabled individuals.

…. The owner of a copyrighted work to transfer or otherwise dispose of his or her copy of the work.

${ }^{19}$ See Copyright Act 1976, Title 17 of U.S.C. 
Computer program is a literary work under copyright law of different Countries and all the provisions affecting literary works apply to computer programs, unless the contrary is stated. For example, a teacher can write a listing of part of a computer program on a black board for the purposes of instruction.

The Copyright, Designs and Patents Act of 1988 of the UK which incorporated the E.C. Software Directives, disclosed the following specially permitted acts for computer programs:

i. decompilation of computer programs;

ii. making back-up copies of computer programs; and

iii. making copies of adaptations of computer programs.

These exceptions to infringement apply only to acts done by lawful users of computer programs.

i. Decompilation: This is a permitted act under copyright which allows lawful users of computer programs to reverse engineer other computer programs for the purpose of achieving 'interoperability' with that or another program. In other words, it allows the act of converting a computer program (the target program) into a form easier to understand (expressed in a higher level language) so that details of its interfaces can be discovered enabling the new program to be compatible with the target program or any program ${ }^{20}$.

ii. Back-up Copies: The Software Directive, and The Copyright, Designs and Patents Act of 1988 of the UK (CDPA 1988) entitles lawful users of a computer program to make necessary back-up copies ${ }^{21}$. Making back-up of computer programs as well as stored data is widely considered a matter of sensible practice. Such practice cannot be prevented by a clause of contract and any of such clause would be void.

ii. Copying and Adapting: A licence in respect of a computer program will normally state the acts that may be done by the licensee in relation to the program. If it is silent about some particular act, which is within the spirit of the agreement, then the courts will imply the appropriate terms permitting that act. Section $50 \mathrm{C}$ of the CDPA of 1988, in effect, put this on a statutory footing by allowing a lawful user of a copy of a computer program to copy it or adapt it if that is necessary for his lawful use. Copying or adapting for the purpose of error correction may fall within this exception to infringement and is given as a particular example in s $50 \mathrm{C}(2)$ of the CDPA of 1988.

\subsection{Jurisdiction, Choice of Law and Enforcement Issues}

E-commerce issues fall under several national jurisdictions. End users can have access to the Internet from any destination of the world. Digitized information can travel across the various countries and jurisdictions, each having its own legal

\footnotetext{
${ }^{20}$ See DI Bainbridge, Intellectual Property, P.217, Fourth Edition, Pitman Publication(1999).

${ }^{21}$ Software Directive, Art. 5 (2) and CDPA 1988, s. 50A.
} 
system, due to the packet-switching technology, complex wave of digital networks and modern telecommunication infrastructure. The jurisdiction, choice of law and enforcement issues in ecommerce have become more complicated because one or more of the parties involved in the transaction including internet users, service and content providers, buyers, sellers, businesses and their assets, technology systems and computer servers may be located in different countries. Uncertainty is not only with regard to the determination of the place of occurrence but also in determining the applicable law and the practicalities of pursuing enforcement or adequate dispute settlement alternatives. In June 1997 the Hague Conference on Private International Law, the Special Commission has developed a "Preliminary Draft Convention on Jurisdictional and Foreign Judgments in Civil and Commercial Matter". But the Commission did not consider e-commerce issues on the Draft Convention. Intellectual Property Infringements, such as infringements of a patent, trademark or copyright, fall under the category of torts or delicts, which is commission of a civil wrong by violating a legal duty. The draft Hague Convention provides that a plaintiff may bring an action in tort or delict in the courts of the State where (a) the act or omission that caused the injury occurred or (b) the injury arose, unless the person claimed to be responsible could not reasonably have foreseen that the act or omission could result in an injury of the same nature in that State $^{22}$. The application of these rules to a copyright dispute in e-commerce is not very much practicable. This is because the determination of the State where the act or omission occurred or the injury arose is not always possible in a dispute of copyright which arose out of e-commerce transaction. When a user in one country or users in multiple countries download an allegedly infringing copy of a copyrighted work from a foreign web site, has a tort "occurred" in the user's forum (i.e., the copying of the work into the memory of the user's computer or other digital device), thus triggering jurisdiction? Or does the tort (unauthorized copying or distribution) occur in the foreign State where the computer server hosting the web site is located, with only an impact in the forum of the user? In the latter case, the foresee ability test (in the draft Hague Convention) may be implicated to determine whether the foreign party would have reasonably foreseen that the publication of the work would have an impact (i.e., cause an injury to the copyright owner) in the user's forum $\operatorname{State}^{23}$.

The Brussels Convention of 1968 has been incorporated into English law by Civil Jurisdiction and Judgments Act of 1982.It provides the jurisdictional rules applicable to civil and commercial cases. The rules apply whenever the defendant is domiciled in a Member State. ${ }^{24}$ In tort or delict-related cases Article 5 (3) of the Convention makes it possible to bring the case before the courts of the country in

\footnotetext{
${ }^{22}$ See draft Convention, Article 10. See also "Information on the Preliminary Draft Convention on Jurisdiction and the Effects of Judgment in Civil and Commercial Matter," available at www.hcch.net/e/convention/draft36e.html, last visited 23 August 2004.

${ }^{23}$ See WIPO, Primer on Electronic Commerce and Intellectual Property Issues, PP.11-13, available at ecommerce.wipo.int/primer, last visited 7 July 2004.

${ }^{24}$ See Paul Torremans, 'Private International Law Aspects of IP-Internet Disputes' P. 226, http://www.Law \& the Internet.com/ a framework for electronic commerce, Edited by Lilian Edwards \& Charlotte Waelde, Hart Publishing (2000).
} 
which the harmful event occurred. The European Court of Justice (ECJ) held that this could mean the place where the damage occurred, as well as the place where the act that gave rise to the damage took place. ${ }^{25} \mathrm{~A}$ copy is made whenever the work is received, even temporarily, in the memory of a computer. ${ }^{26}$ Article 5(3) therefore opens up the possibility of suing the defendant wherever such a copy is made. Article 6(1) of the Convention deals with the Internet cases against multiple defendants, with domicile in more than one State. ${ }^{27}$ This Article allows the plaintiff to sue a defendant who is domiciled in a contracting State in the court of the country where one of his co-defendants is domiciled, in case there is more than one defendant. This makes it possible to bring a single case against all defendants in a single court. This provision allowed the applicant in Pearce v. Arup to sue all defendants in the UK for breach of his United Kingdom and his dutch copyright in respect of architectural plans for a building, even though only the first defendant was domiciled in that contracting State. ${ }^{28}$

In respect of choice of law, a problem arises regarding the country of origin where a work published on the Internet and is available in all countries simultaneously. According to the Berne Convention only one country can be the country of origin despite of simultaneous publication of a work in several countries. ${ }^{29}$ The law of the country of origin was applied by the second Circuit Court of the USA in Itar-Tass Russian News Agency v. Russian Kurier, Inc. ${ }^{30}$ despite the fact that the court labeled it the law of the country with the 'most significant relationship' to the work. However problems can be anticipated in this area because the location of web site may be impossible to determine, or the Web site may have no relationship to the author. ${ }^{31}$

For the enforcement of judgment the provisions of EC Regulation on Jurisdiction and enforcements in Civil and Commercial matters can be considered. It has been stated in the preamble of the Regulation that For the purposes of the free movement of judgments, judgments given in a Member State bound by this Regulation should be recognised and enforced in another Member State bound by this Regulation, even if the judgment debtor is domiciled in a third State. ${ }^{32}$ The Regulation divides jurisdiction into three categories, i.e. general jurisdiction, special jurisdiction and exclusive jurisdiction. Article 2 (1) of the Regulation provides that "[s]ubject to this Regulation, persons domiciled in a Member State shall, whatever their nationality, be sued in the courts of that Member State.

${ }^{25}$ Case 21/76, Handelskwekerij GJ Bier v. Mines de Potasse d' Alsace [1976] ECR 1735.

${ }^{26}$ See MAI Sys Corp v. Peak Computer Inc, 991 F 2d 511, 517 ( $9^{\text {th }}$ Circuit 1993) and see also Ginsburg, Private International Law Aspects of the Protection of Works and Objects of Related Rights Transmitted through Digital Networks, WIPO Paper, Nov. 1998(available as GCPIC/2 paper on the WIPO website), P 14.

${ }^{27}$ See Paul Torremans, 'Private International Law Aspects of IP-Internet Disputes' P. 230, http://www.Law \& the Internet.com/ a framework for electronic commerce, Edited by Lilian Edwards \& Charlotte Waelde, Hart Publishing (2000).

\footnotetext{
${ }^{28}$ Upheld in appeal, see pearce v. Ove Arup Partnership Ltd. and others [1999] 1 All ER 769.

${ }^{29}$ Article 5 (4) of the Berne Convention.

${ }^{30} 153 \mathrm{~F} 3 \mathrm{~d}$ 82, 47 USPQ2D 1810.

${ }^{31}$ See Bruce A. McDonald, 'Intellectual Property Rights And Electronic Commerce', available at www.wrf.com/db30/cgi-bin/pubs/ip_ecommerce.pdf, last visited 24 August 2004.

${ }^{32}$ See Council Regulation (EC) No. 44/2001, enforced on 1 March 2002.
} 
Article 5(3) provides jurisdiction for tort, delict and quasi-delict. The provision states "in matters relating to tort, delict or quasi-delict, in the courts

for the place where the harmful event occurred or may occur" . Article 22 (4) provides that in proceedings concerned with the registration or validity of patents, trade marks, designs, or other similar rights required to be deposited or registered, the courts of the Member State shall have the exclusive jurisdiction, regardless of domicile in which the deposit or registration has been applied for, has taken place or is under the terms of a Community instrument or an international convention deemed to have taken place.

Things become complicated when in an internet related case, the alleged infringement of intellectual property rights by the same defendant occurred in more than one jurisdiction. Ideally a single case against the defendant should be the solution. The present Internet context summons the introduction of a new jurisdiction rule that would allow the plaintiff to sue in its country of domicile for the global infringement of its rights. Such a rule may in the end be inevitable to preserve the right holder's rights in the Internet age, even if it presents a radical departure from existing private international law principles. ${ }^{33}$

${ }^{33}$ Case C-68/93, Fiona Shevil v. Presse Alliance [1995] ECR I-415. 


\section{Internet Piracy: A Grave Challenge}

\subsection{Forms of Internet Piracy}

Internet piracy is the most rapidly expanding type of piracy and the most difficult form to combat. Internet piracy takes many forms:

Auction Site Piracy;

Bulletin Board Services \& News group piracy;

FTP Sites;

Warez;

Peer-to-Peer;

Cracks/Serial Numbers sites; and

Internet Relay Chat.

(i) Auction site piracy occurs when the seller burns software onto CD-ROMs, offers the software for sale in an online auction. The auctioneer often preserves the names and e-mails of losing bidders and contacts those bidders in an attempt to sell additional copies.

One example of a pirate auction is provided below ${ }^{34}$ :

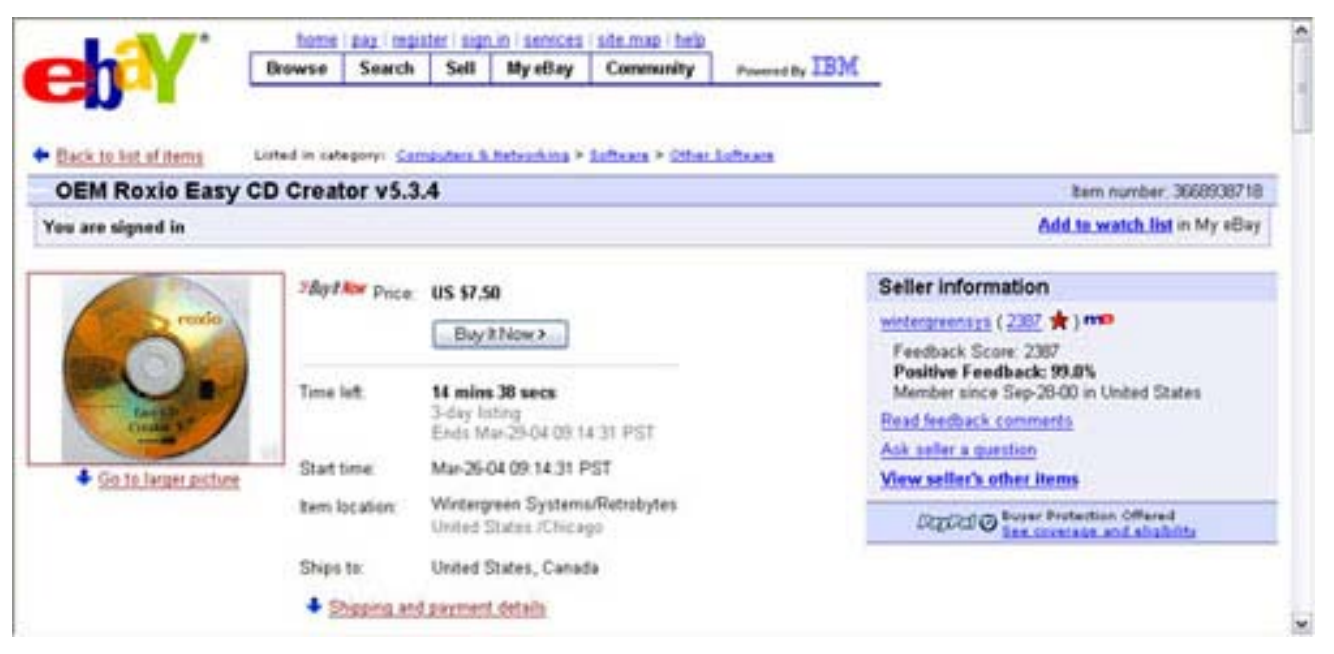

${ }^{34}$ See at www.siia.net, last visited 4 July 2004. 
(ii) FTP allows one to upload files and download files to a site. Software pirates who transfer programs to one another commonly use FTP sites because it is efficient for transferring large files and most FTP servers support some form of anonymous login.

A sample FTP pirate site follows ${ }^{35}$ :

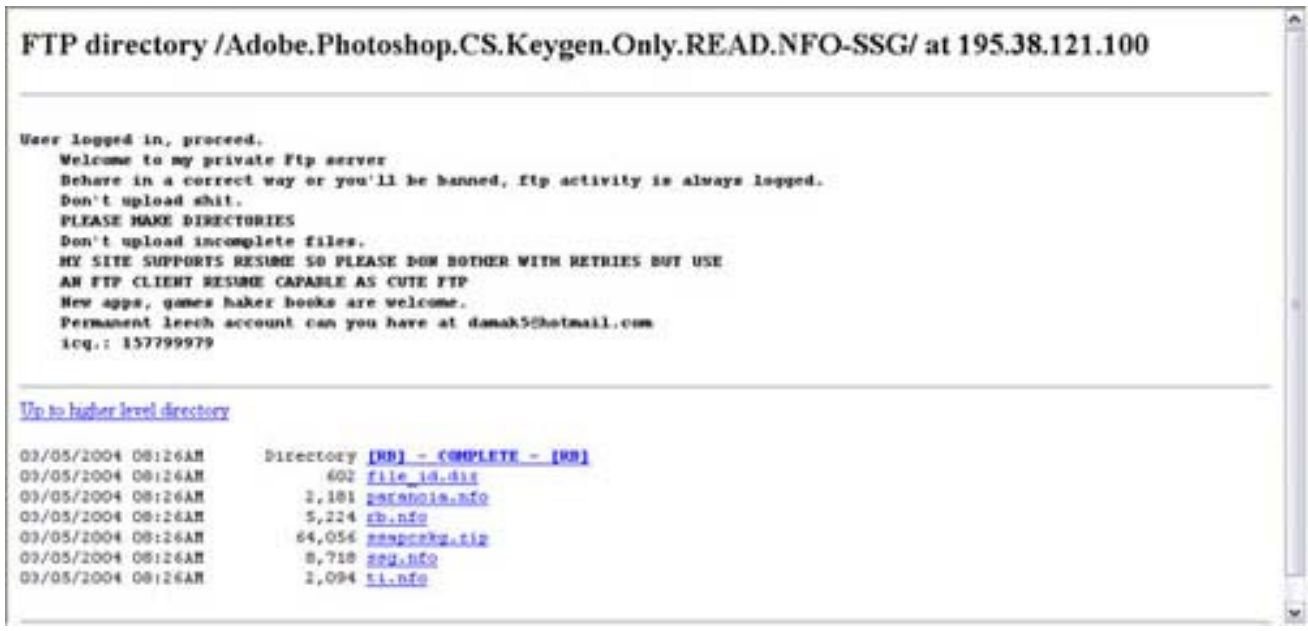

(iii) Web sites, often called Warez Sites allow the downloading of software -generally free of charge -- from the $\mathrm{Web}^{36}$.

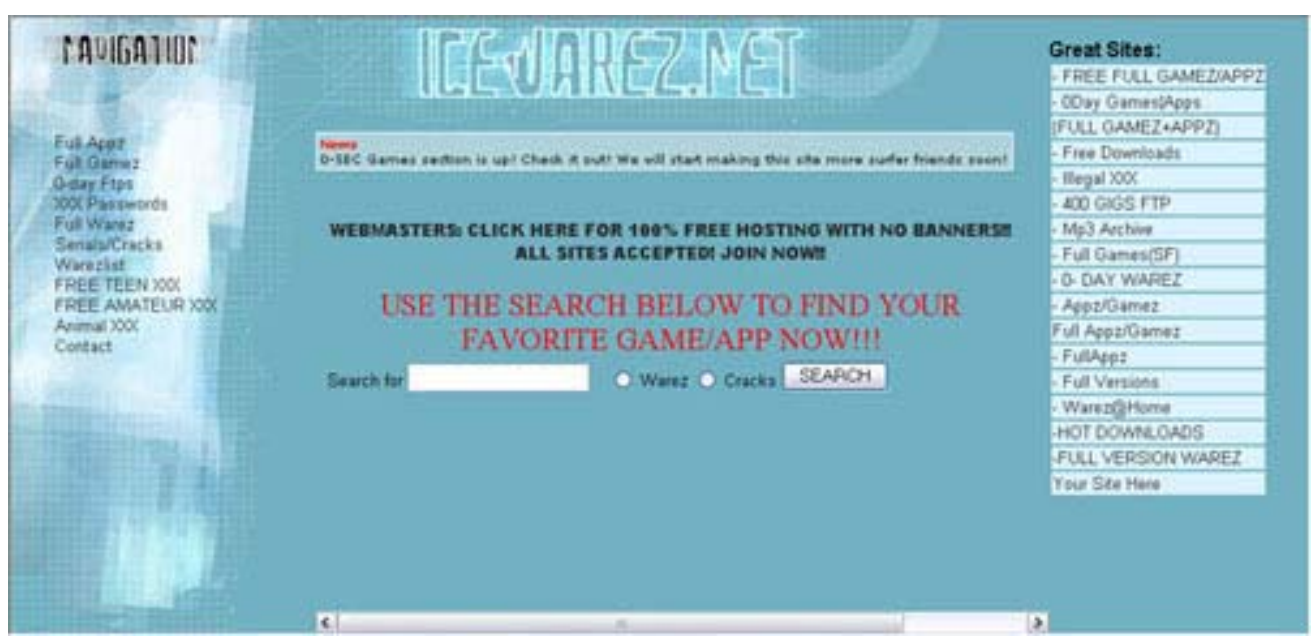

(iv) Peer-to-Peer [P2P] technologies allow users to communicate in real-time and transfer files to each other. Because of the distributed and often anonymous nature of P2P sites, they are widely used for distribution of unauthorized software and content. P2P networks are also popular because they are basically "one stop shopping" where a user can find just about anything they are looking for - music, software, movies. Of all the forms of piracy discussed, P2P piracy is the most

\footnotetext{
${ }^{35}$ See ibid F.N.34.

${ }^{36}$ See ibid F.N.34.
} 
difficult to stop. The example below is from the P2P network Gnutella ${ }^{37}$.

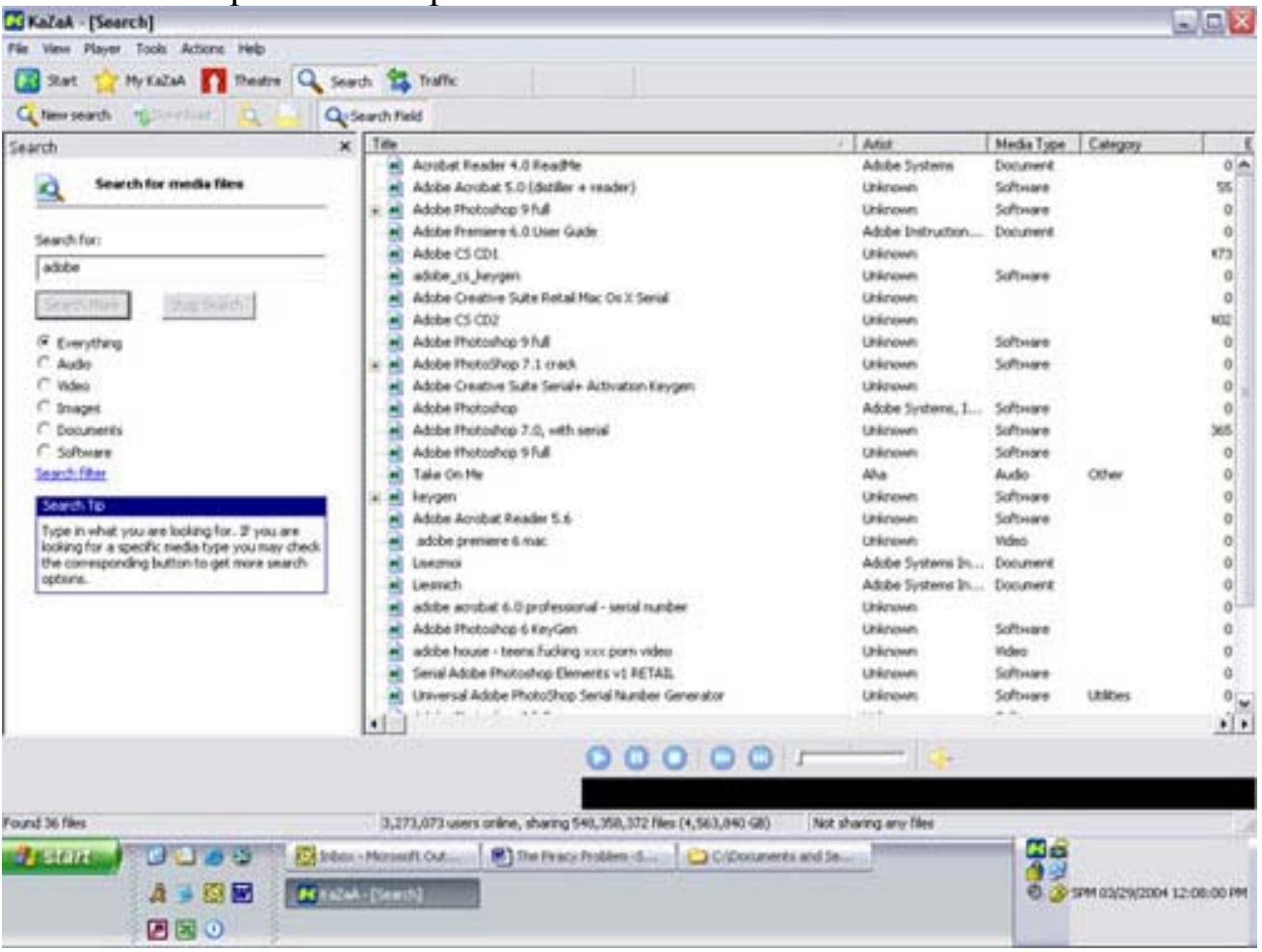

(v) Another form of piracy that is prevalent on the Internet is the use of cracks, key-generators and patches. Cracks and patches are small files that circumvent copyright protection -- either technical access or copy restrictions -- by altering the source code. A key-gen or key generator is an application that uses the serial number or CD key-generating algorithm to create fake, yet still valid, serial numbers and CD keys. A site that provides these technologies looks like this ${ }^{38}$ :

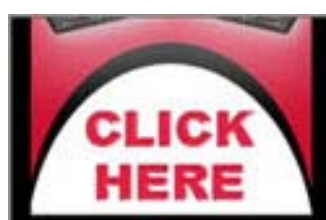

astalavista's banner

add astalavista search to your page

terms of use

privacy policy

Get your astalavista shirt nowl

for technical problems and advertising related

information contact (

\footnotetext{
${ }^{37}$ See ibid F.N.34.

${ }^{38}$ See ibid F.N.34.
}

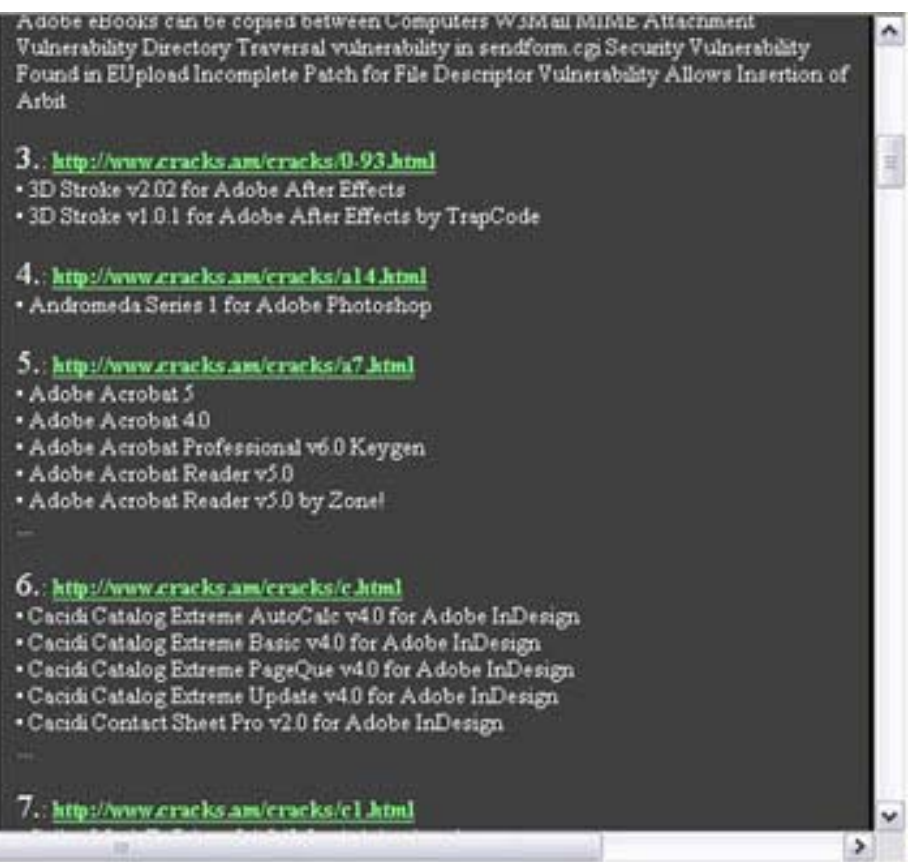

Vulnerability Directory Traversal valnetrablity in sendform ces Secuaty Vulnerobely

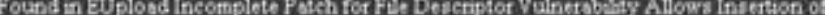

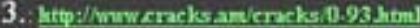

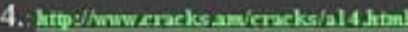

5. hiph/hwweneksanicreksin html

Adobe Actobat Profeseniond vo 0 Koygen

- Adobe Acrobat Reader v5

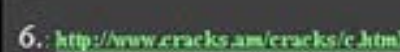

- Cacidi Catalog Extseme AutoCalo v40 for A dobe InDesigr

- Cacidi Catalog Eatrent Basic va 0 for A dobe InDesigr

- Cacia Casalog Eatreme PageQue valo for Adobe in Desig

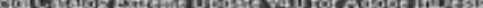

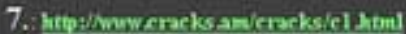




\section{(vi) Types of Content Piracy}

In addition to the methods listed above for software piracy, content piracy can be committed in a wide variety of ways:

Web framing can be a form of piracy when a viewing window is created for all or a portion of a Web page or a particular piece of content residing on a Web page. Problems with framing typically arise where the manner in which the Web site is framed removes, obscures, or alters navigation tools, links, and indicators of source, trademarks, logos, or advertising located on the Web site that is framed. Framing of third-party content into another Web page raises many legal issues, including passing off content as one's own, unfair competition, trademark infringement, trademark dilution, misappropriation, and perhaps copyright infringement. E-mail as a redistribution vehicle for copyrighted materials can easily extend distribution well past the boundaries of authorized original use. Forwarding a URL link is generally acceptable, since all of the original material is maintained and only a "direction" is passed on to another user. However, copying Web site content and pasting it into an e-mail to send to another person or persons may well constitute unauthorized copying and/or distribution. Whether it does will depend on the nature of the material copied, the purpose of the e-mail, the number of recipients, the identity of the recipients, and the effect that the e-mail distribution has on the market for the copyrighted content forwarded in the email-all factors associated with the rights and exceptions established under copyright law. Print uses of digital content frequently require an appropriate permission granted by the copyright owner(s) or publisher. A typical license agreement may grant the right to print one to five copies for personal use. Production of large quantities, or capturing, reformatting, and republishing the content using a publishing program will likely require permission from the content owner(s). Scanning occurs when an individual uses a device to copy a printed work to a digital format and then makes the digital format available to others online through some form of electronic distribution.

Transferring passwords is usually a violation of the terms of use of a subscription or other agreement to access copyrighted works online. Sharing passwords is a separate access violation under the Digital Millennium Copyright Act, where the password is used to prevent unauthorized access.

\subsection{How Internet Piracy Occurs}

Technology and the Internet have come a long way since the Internet's inception, creating various avenues of how one transfers data over the Internet, such as: Web sites, e-mail, online chat, file transfer protocols (FTP), and the list goes on and on. Though this may be good for evolving the Internet into a global information center, it is not so good for preventing software piracy from occurring. In fact, these avenues create ways for piracy to flourish. Now software pirates can use these avenues as ways to communicate and share files with one another in real time. Today people use Internet Relay Chat (IRC) to discuss just about any subject with anybody, anywhere, in real-time. People from all over the world gather in chat rooms where everyone within the chat room talks about certain subjects. Software pirates use IRC to create chat rooms in which they can come 
together and discuss software piracy. They converse about which crackz, warez, serialz, gamez and appz are the best; and then they tell each other about where to find them for free or for an extremely discounted price. The chat rooms allow pirates to share with one another their warez and FTP sites that contain pirated software. As the blatancy of piracy grows within such chat rooms and warez sites, the policing of such piracy grows as well, pushing pirates to pursue other ways to communicate and distribute pirated software with one another. Pirates are now using software and other technologies, such as Gnutella, to help them distribute unauthorized material to one another. Gnutella allows users to communicate in real time and distribute files amongst each other while being virtually anonymous. Gnutella may not necessarily have been developed for the software pirate, but has now become a software pirate's dreamed tool: pirating with virtual anonymity. Pirates not only distribute software among themselves; they now are starting to reach out to the general public through online auction sites. Several auction sites have become virtual "pirate havens."

The face of software piracy is ever-changing, especially in the online world. With recordable CD ROM drives (CD-R's and CD-RWs) being built into an increasing number of computers, the industry is faced with the growing threat of "homepirates." These pirates can now make perfect copies of software and hand them out to their friends, sell them at weekend computer trade shows or via the Internet. In addition, users are setting up their own Web sites allowing the illegal distribution of software and digital content to a global audience. Pirate sites are now not only found on Web sites, but also on hotline servers, online auction sites, IRC, newsgroups and through e-mail solicitations. It has been seen a jump in the number of cases of e-mail and "snail mail" solicitation cases, where a pirate offers thousands of dollars worth of software for only a few hundred dollars. The professional pirates in these cases "burn" or record these titles onto blank, recordable CDs. They then send out mass e-mail or direct mail solicitations to sell the software copies that they have manufactured. In a recent case of direct mail solicitation detected in the U.S.A. where the infringer was offering roughly $\$ 15,000$ worth of software on a set of CDs for only a few hundred dollars. The ease of duplication, coupled with the ease of downloads from the Internet through DSL and cable modem connections, means that federal law enforcement agencies now face numerous new and challenging avenues of trafficking pirated software ${ }^{39}$.

\subsection{Analysis of Important Cases on Internet Piracy}

Since the United States has a considerably developed law and case law regarding protection of intellectual property on the software and the Internet, therefore it would be relevant and useful to refer to some important US cases on the present topic. Some of the important US cases are as follows:

(i) Adobe Systems, Inc. v. Ajine ${ }^{40}$ : The plaintiffs, Adobe Systems, Inc. and Alias/Wavefront, Inc., alleged that defendant Fadi Ajine, an individual residing in Charlottesville, Virginia, was illegally copying their software products and

\footnotetext{
${ }^{39}$ See Ibid.

${ }^{40}$ See 2001 WL 252916, 2001 WL 252916 (W.D.Va.).
} 
auctioning the pirated copies on the Internet. The plaintiffs filed this case under seal, did not serve a summons on Ajine, and requested an immediate $e x$ parte hearing. For this reason, Ajine was unaware he has been sued. The plaintiffs sought a "seizure order," by which they wanted the court to send the U.S. Marshals to Ajine's home to seize and impound any evidence of piracy. They also sought a preliminary injunction and an order for expedited discovery. Because the plaintiffs had not shown why these motions should be granted ex parte, without giving Ajine notice of these proceedings or even notice that he had been sued, the motions was denied.

The fact of the case in a nutshell is that In November 2000, Michael Flynn, an employee at a non-profit association that works with the plaintiffs to combat software piracy, observed that copies of the plaintiffs' software were being offered for sale at forty-two different auctions on the Internet. To catch Ajine red-handed, the plaintiffs orchestrated a type of "sting" operation prior to filing the suit. Flynn sent an e-mail to the address associated with the seller, "creativityforever @hotmail.com," to see if any more auctions would be held. Although the name associated with that e-mail address was "Cynthia McNamera." Flynn believed Ajine was the one who actually used that address. "McNamera" responded that an auction was unnecessary, and offered to sell the plaintiffs' software products for the same price they sold for at auction. Flynn wrote back, asking to buy specific products normally valued at $\$ 20,000$. "McNamera" replied that "she" would sell them for $\$ 125$, and told Flynn to send the payment to Ajine at a particular address in Charlottesville. Flynn did so. On December 8, 2000, he received several CDROMs containing copies of the plaintiffs' software. The CD-ROMs had handwritten installation instructions and bore no indicia of copyright. The package contained none of the artwork or inserts that typically accompany the plaintiffs' products. Flynn believes Ajine sold him unlicenced software, and had done so to others. The plaintiffs filed a complaint against Ajine on January 29, 2001. With the complaint, the plaintiffs filed a motion to seal the case, which the court granted. The plaintiffs also immediately requested an ex parte hearing, which took place on February 9, 2001. The plaintiffs sought three orders at the ex parte hearing: (1) a preliminary injunction, to prohibit Ajine from selling unauthorized copies of the plaintiffs' copyrighted software products and from destroying evidence of infringement: (2) a seizure order, for seizure and impoundment of any illegally made copies of the software, printouts of the plaintiff's computer directories, copies of Ajine's invoices pertaining to illegal sales, and any other tangible evidence of copyright infringement: and (3) and order for expedited discovery.

The Court carefully examined the plaintiff's claim and rejected all on the following grounds:

The plaintiffs first move for a preliminary injunction. In Consolidation Coal Co. V. Disabled Miners of Southern West Virginia, 442 F. 2d 1261(4 th Cir. 1971), the Fourth Circuit examined the issuance of an ex parte preliminary injunction issued without notice. The court determined that "[t]his was manifestly error, because Rule 65(a)(1) is explicit that '[n]o preliminary injunction shall be issued without notice." (quoting Fed. R. Civ. P. 65 (a)(1)). Therefore, the plaintiffs' ex 
parte motion for a preliminary injunction must be denied.

Assuming the plaintiffs intended to move for a temporary restraining order (TRO), the following four factors must be balanced: (1) the likelihood of irreparable harm to the plaintiff if the TRO is not granted; (2) the likelihood of harm to the defendant if the TRO is granted; (3) the likelihood that plaintiff will succeed on the merits; and (4) the public interest.

Accordingly, the plaintiffs' Rule 65 (b) application was deficient on its face because the plaintiffs had not shown that proceeding ex parte was the "sole method of preserving a state of affairs in which the court could provide effective final relief." Adobe Sys., 187 F.F.D. at 643. The plaintiffs had not shown Ajine was likely to destroy evidence, and they already had substantial evidence of infringement. If infringement was shown, Ajine would be permanently enjoined from infringing further, and would be subject to contempt if he violated the injunction. The plaintiffs' concerns about ongoing infringement could be addressed by filing a fully-noticed motion for a preliminary injunction under Rule 65(a).

The plaintiffs also moved for a seizure order. Essentially the plaintiffs asserted that if Ajine found out about this lawsuit, he had a strong incentive to destroy any evidence of his piracy, including any pirated copies of the plaintiffs' products. The plaintiffs claimed that the court had the authority to order such a seizure under: the Copyright Act,17 U.S.C.§ 503: the All Writs Act,28 U.S.C. § 1651 (a); and Rule 65(b). The Court carefully examined the laws and found that neither the Copyright Act, the All Writs Act, nor Rule 65 supported the plaintiffs' request for an ex parte seizure order. The court also was strongly disinclined to order such a seizure because Ajine was an individual. The plaintiffs' argument that this fact weighed in favor of seizure was not welltaken. The bedrock proposition that "a man's home is his castle," dates "[a]s far back as Semayne's Case of 1604." Minnesota v. Carter, 525 U.S. 83, 94 (1998) (Scalia, J., concurring). Absent a strong showing that had not been made here, the court shall not disturb this proposition by deploying the U.S. Marshals in a civil action to the home of a man who had no notice he had been sued and no opportunity to be heard, to ransack his personal effects and seize whatever they or the plaintiffs' counsel deemed to be evidence of copyright infringement.

The plaintiffs also moved for expedited discovery because Ajine's alleged conduct "demonstrated a need for swift action." The plaintiffs having failed to show why any motion should be granted ex parte, this motion was also denied.

(ii) METRO-GOLDWYN-MAYER STUDIOS, INC. v. GROKSTER ${ }^{41}$ : Organizations in motion picture and music recording industries sued Internet software distributors for contributory and vicarious copyright infringement. On cross motions for summary judgment, the District Court, Wilson, J., held that: (1) distributors were not liable for contributory infringement absent showing that they had any material involvement in users' conduct, and (2) distributors were not

${ }^{41}$ See 259 F.Supp.2d 1029 (C.D.Cal. 2003) . 
liable for vicarious infringement absent showing that they had any right or ability to supervise users' conduct. Plaintiffs' motion denied; defendants' motion granted.

With Metro Goldwyn case another case, Jerry Lieber V. Consumer Empowerment was consolidated for discovery and pretrial purposes.

The facts of the cases in a nutshell is that these cases arose from the free exchange of copyrighted music, movies and other digital media over the Internet. When the actions were originally filed, Defendants Grokster, Ltd. ('Grokster'), StreamCast Networks, Inc. (formerly known as MusicCity Networks, Inc.) ("StreamCast'), and Kazaa BV (formerly known as Consumer Empowerment BV) ("Kazaa BV'), distributed software that enabled users to exchange digital media via a peer-to-peer transfer network. In the Metro-Goldwyn-Mayer $v$. Grokster case, CV-01-8541, Plaintiffs are organizations in the motion picture and music recording industries, and brought this action against Defendants for copyright infringement, pursuant to 17 U.S.C. $\S \S 501$, et seq. In the Lieber $v$. Consumer Empowerment case, CV-01-9923, Plaintiffs are professional songwriters and music publishers who brought a class action against the same Defendants for copyright infringement, although their Complaint lists separate causes of action for contributory infringement and vicarious infringement. Each Defendant distributes free software, which users can download free of charge. Although Grokster, StreamCast and Kazaa BV independently branded, marketed and distributed their respective software, all three platforms initially were powered by the same FastTrack networking technology. The FastTrack technology was developed by Defendants Niklas Zennstr" om and Janus Friis, who also launched Kazaa BV.2 FastTrack was then licensed to Kazaa BV, Grokster and StreamCast for use in each company's filesharing software. As a result, users of these software platforms essentially were connected to the same peer-to-peer network and were able to exchange files seamlessly. However, StreamCast no longer uses the FastTrack technology. Rather, StreamCast now employs the "open" (i.e., not proprietary) Gnutella technology, and distributes its own software-Morpheus - instead of a branded version of the Kazaa Media Desktop. Grokster, meanwhile, continues to distribute a branded version of the Kazaa Media Desktop, which operates on the same FastTrack technology as the Sharman/Kazaa software.

In these cases the Court explained the operation of the Stream Cast (Morpheus) and Grokster Software. The Court opined that although novel in important respects, both the Grokster and Morpheus platforms operate in a manner conceptually analogous to the Napster system described at length by the district court in A \& M Records, Inc. v. Napster, Inc., 114 F.Supp.2d 896 (N.D.Cal.2000). In both cases, the software can be transferred to the user's computer, or "'downloaded," from servers operated by Defendants. Once installed, a user may elect to "share" certain files located on the user's computer, including, for instance, music files, video files, software applications, ebooks and text files. When launched on the user's computer, the software automatically connects to a peer-to-peer network (FastTrack in Grokster's case; Gnutella in the case of Morpheus), and makes any shared files available for transfer to any other user currently connected to the same peer-to-peer network. Both the Morpheus and Grokster software provide a range of means through which a user may search 
through the respective pool of shared files. For instance, a user can select to search only among audio files, and then enter a keyword, title, or artist search. Once a search commences, the software displays a list (or partial list) of users who are currently sharing files that match the search criteria, including data such as the estimated time required to transfer each file. The user may then click on a specific listing to initiate a direct transfer from the source computer to the requesting user's computer. When the transfer is complete, the requesting user and source user have identical copies of the file, and the requesting user may also start sharing the file with others. Multiple transfers to other users ("uploads"), or from other users "downloads"), may occur simultaneously to and from a single user's computer. Both platforms include other incidental features, such as facilities for organizing, viewing and playing media files, and for communicating with other users.

The Court meticulously explained the distinctions between the Napster case and the present cases. The Court held that Plaintiffs appear reluctant to acknowledge a seminal distinction between Grokster/ StreamCast and Napster: neither Grokster nor StreamCast provides the "site and facilities" for direct infringement. Napster, 239 F.3d at 1022. Neither StreamCast nor Grokster facilitates the exchange of files between users in the way Napster did. Users connect to the respective networks, select which files to share, send and receive searches, and download files, all with no material involvement of Defendants. If either Defendant closed their doors and deactivated all computers within their control, users of their products could continue sharing files with little or no interruption. (See, e.g., Gribble Decl. 9ๆ 7, 13, 18, 21, 23, 27, 32, and 34; D. Rung

Decl. I 6.) In contrast, Napster indexed the files contained on each user's computer, and each and every search request passed through Napster's servers. Napster, 239 F.3d at 1012. Napster provided the "site and facilities" for the alleged infringement, id. at 1022, affording it perfect knowledge and complete control over the infringing activity of its users. If Napster deactivated its computers, users would no longer be able to share files through the Napster network.

A number of important rulings came out of these two cases, which are as follows:

(a) To establish prima facie case of copyright infringement, plaintiff must show: (1) copyright ownership of allegedly infringing material, and (2) unauthorized copying of work that is original.

(b) Users of Internet software to upload and download copyrighted music files were engaged in direct copyright infringement, for purpose of determining whether software distributors were liable for contributory or vicarious infringement.

(c) Evidence of actual knowledge of specific acts of copyright infringement is required for contributory infringement liability.

(d) Distributors of Internet software that enabled users to exchange digital media via peer-to-peer transfer network were not liable for contributory copyright infringement, even if they were aware that software was being used to infringe copyrighted works; there were also substantial non infringing uses for software, and distributors had no material involvement in users' conduct. 
(e) Distributors of Internet software that enabled users to exchange digital media via peer-to-peer transfer network were not liable for vicarious copyright infringement, though they derived financial benefit from enabling users' direct infringement, absent showing that they had right or ability to supervise users' conduct.

(f) Elements of vicarious copyright infringement claim are: (1) financial benefit, and (2) defendant's right and ability to supervise infringing conduct.

It is apparently clear from the rulings of these cases that it is very difficult to make liable the distributors of Internet software in a case of vicarious infringement claim where software could be transferred through P2P file sharing. So it would be a real difficult position to find out the individual users and fix liability on them. To justify a judicial remedy in these cases the plaintiffs requested the Court to expand copyright Law beyond its existing well-known boundaries. The Court refused to do so and opined that this is the responsibility of the legislature even where was an apprehension that the defendants may have intentionally structured their businesses to avoid secondary liability for copyright infringement, while benefiting financially from the illicit draw of their wares.

But in this case the malafide intention of the defendant could be the basis of the court's action in order to secure justice and the court may not be confined to the technicalities of the law. Though in the theory of the Separation of Power one organ of the State should not interfere with the responsibility of another organ of the State, instead of that in a suitable case court's interference is needed in order to ensure the justice and balance of power among the organs of the State. Since the trying court was a District Court therefore, its power was very limited in this regard.

(iii) UNIVERSAL CITY STUDIOS, INC. v. CORLEY ${ }^{42}$ : The Motion picture studios brought action under Digital Millennium Copyright Act (DMCA) to enjoin Internet web site owners from posting for downloading computer software that decrypted digitally encrypted movies on digital versatile disks (DVDs) and from including hyperlinks to other web sites that made decryption software available. The United States District Court for the Southern District of New York, Lewis A. Kaplan, J., granted injunction on behalf of studios, 111 F.Supp.2d 294, and 111 F.Supp.2d 346. The Web site owners appealed. The Court of Appeals, Jon O. Newman, Circuit Judge, held that: (1) software program qualified as "speech" for First Amendment purposes; (2) computer code combined nonspeech and speech elements; (3) injunction was content neutral restriction on owners' speech; (4) injunction did not burden substantially more speech than necessary to further government's interest; and (5) injunction did not unconstitutionally eliminate owners' "fair use" of copyrighted materials. The trial Court judgment was affirmed in the appeal.

${ }^{42}$ See 273 F.3d 429 (2nd Cir. 2001). 
The facts of the case in a nutshell are that in November 1999, Corley posted a copy of the decryption computer program "DeCSS"43 on his web site, http:// www.2600.com ("2600.com").2 DeCSS is designed to circumvent Content Scramble System ("CSS") ${ }^{44}$, the encryption technology that motion picture studios place on DVDs to prevent the unauthorized viewing and copying of motion pictures. Corley also posted on his web site links to other web sites where DeCSS could be found. Plaintiffs \pm Appellees are eight motion picture studios that brought an action in the Southern District of New York seeking injunctive relief against Corley under the DMCA. Following a full nonjury trial, the District Court entered a permanent injunction barring Corley from posting DeCSS on his web site or from knowingly linking via a hyperlink to any other web site containing DeCSS. Universal II, 111 F.Supp.2d at 346 \pm 47 . The District Court rejected Corley's constitutional attacks on the statute and the injunction. Universal I, 111 F.Supp.2d at $325 \pm 45$. Corley renewed his constitutional challenges on appeal. Specifically, he argued primarily that:

(1) the DMCA overstepped limits in the Copyright Clause on the duration of copyright protection;

(2) the DMCA as applied to his dissemination of DeCSS violated the First Amendment because computer code is "speech" entitled to full First Amendment protection and the DMCA fails to survive the exacting scrutiny accorded statutes that regulate "speech"; and

(3) the DMCA violates the First Amendment and the Copyright Clause by unduly obstructing the "fair use" of copyrighted materials. Corley also argued that the statute was susceptible to, and should therefore be given, a narrow interpretation that avoids alleged constitutional objections.

Invoking subsection 1203(b)(1) of the DMCA, the Plaintiffs sought an injunction against the Defendants, alleging that the Defendants violated the anti-trafficking provisions of the statute. On January 20, 2000, after a hearing, the District Court issued a preliminary injunction barring the Defendants from posting DeCSS.

Universal City Studios, Inc. v. Reimerdes, 82 F.Supp.2d 211 (S.D.N.Y.2000). The Defendants complied with the preliminary injunction, but continued to post links to other web sites carrying DeCSS, an action they termed "electronic civil disobedience." Universal I, 111 F.Supp.2d at 303, 312. Under the heading "Stop the MPAA [(Motion Picture Association of America)]," Corley urged other web sites to post DeCSS lest "we TTT be forced into submission." Id. at 313. The Plaintiffs then sought a permanent injunction barring the Defendants from both

\footnotetext{
43 DeCSS is a decryption program executable on Microsoft's operating system. If a user runs the DeCSS program (for example, by clicking on the DeCSS icon on a Microsoft operating system platform) with a DVD in the computer's disk drive, DeCSS will decrypt the DVD's CSS protection, allowing the user to copy the DVD's files and place the copy on the user's hard drive.
}

\footnotetext{
${ }^{44}$ CSS is an encryption scheme that employs an algorithm configured by a set of "'keys" to encrypt a DVD's contents. The algorithm is a type of mathematical formula for transforming the contents of the movie file into gibberish; the "keys" are in actuality strings of 0 's and 1's that serve as values for the mathematical formula.
} 
posting DeCSS and linking to sites containing DeCSS. After a trial on the merits, the Court issued a comprehensive opinion, Universal I, and granted a permanent injunction, Universal II.

The district court rejected all of the defenses. It categorically concluded that defendants

failed to satisfy the conditions for coming within the three Section 1201 exemptions that they claimed applied to their activities (reverse engineering, encryption research and security testing). It also found that fair use does not apply in an action brought under Section 1201. The defendants were ordered not to post DeCSS on their Website. The injunction also prohibited the defendants from linking to other sites that carried DeCSS. The court noted that enjoining such linking would help to prevent the spread of DeCSS, especially where the links are to Websites outside the United States of America.

In November 2001, the U.S.A. Court of Appeals for the Second Circuit affirmed the decision of the district court in all respects. The court found that the injunction was constitutional because it was "content-neutral"-it targeted only the functional, non-speech components of the decryption code (and, in the case of linking, only the functional, not expressive, aspects of the hyperlink)-and it had only an incidental effect on the defendants' speech. The court of appeals specifically examined the question of whether circumvention of CSS was permitted where done to aid in a fair use of motion pictures on DVD video disks. Interpreting Section 1201(c)(1), the court concluded that the DMCA target the circumvention of digital protections through its anti-trafficking provisions, but does not concern itself with the use of the content after circumvention has occurred. It rejected the notion that Congress intended to permit "fair use" circumvention. Finally, the court disagreed with defendants' position that the DMCA was unconstitutional insofar as it eliminated the ability to make fair use of copyrighted works protected by access control; the court found that the fair use doctrine did not guarantee that anyone would have access to copyrighted material.

The Court settled a number of important rulings in this case. These are as follows:

(a) Those persons who "decrypt" an encrypted digital versatile disk (DVD) with the authority of a copyright owner are exempted from liability under the Digital Millennium Copyright Act (DMCA); however, authority to "view" a DVD does not create a right to decrypt a DVD. 17 U.S.C.A. § 1201(a)(3)(A).

(b) Injunction, which prevented Internet web site owners from providing hyperlinks to other web sites that posted decryption code, was unrelated to suppression of free expression, in lawsuit brought by motion picture studios under Digital Millennium Copyright Act (DMCA); although hyperlink had speech component, linking prohibition applied whether or not the hyperlink contained any information, comprehensible to a human being, as to Internet address of web page accessed. U.S.C.A. Const. Amend. 1; 17 U.S.C.A. § 1201 et seq.

(c) Injunction under Digital Millennium Copyright Act (DMCA), that barred Internet web site owner from trafficking in decryption code that enabled unauthorized access to copyrighted materials, did not unconstitutionally eliminate owners' "fair use" of copyrighted materials; owners did not claim to be making 
fair use of any copyrighted materials and nothing in injunction prohibits them from making such fair use, and owners failed to establish that anti-trafficking provisions of DMCA prevented other persons from copying portions of DVD movies in order to make fair use of them. U.S.C.A. Const. Art. 1, § 8, cl. 8; 17 U.S.C.A. $\S 1201$ et seq.

This case upholds the constitutionality of DMCA and prohibits Internet web site owners from posting for downloading computer software that decrypted digitally encrypted movies on digital versatile disks (DVDs) and from including hyperlinks to other web sites that made decryption software available. This is a remarkable development in the protection of software on the Internet in other words in eCommerce. 


\section{Software Patenting vis-à-vis Copyright}

\subsection{A Brief History of Software Patenting}

The United States is the pioneer in granting software patent. Therefore in order to discuss the history of software patenting we have to take notice of the history of US Software patenting.

The U.S. Patent and Trademark (USPTO) Office historically has been reluctant to grant patents on inventions relating to computer software. In the 1970s, the USPTO. avoided granting any patent if the invention utilized a calculation made by a computer. Its rationale was that patents could only be granted to processes, machines, articles of manufacture, and compositions of matter. Patents could not be granted to scientific truths or mathematical expressions of it. The USPTO. viewed computer programs and inventions containing or relating to computer programs as mere mathematical algorithms, and not processes or machines. As such, software related inventions were considered non-statutory ${ }^{45}$.

In the 1980s, the Supreme Court forced the USPTO. to change its position. The 1981 case of Diamond v. Diehr provided the first instance in which the U.S. Supreme Court ordered the USPTO. to grant a patent on an invention even though computer software was utilized. In that case, the invention related to a method for determining how rubber should be heated in order to be best "cured." The invention utilized a computer to calculate and control the heating times for the rubber. However, the invention (as defined by the claims) included not only the computer program, but also included steps relating to heating rubber, and removing the rubber from the heat. The Supreme Court stated that in this case, the invention was not merely a mathematical algorithm, but was a process for melting rubber, and hence was patentable. This was true even though the only "novel" feature of this invention was the timing process controlled by the computer ${ }^{46}$.

After 1981, the USPTO. and inventors were left trying to determine when an invention was merely a mathematical algorithm, and when it was in fact a patentable invention that simply contained a mathematical algorithm. Although lower courts attempted to set forth this distinction in a clear manner, the resulting opinions were generally quite confused. What was clear was that the patentability of a software related invention depended heavily on the claims created by the patent attorney.

In the early 1990s, the Federal Circuit (the highest court for patent matters other than the Supreme Court) tried to clarify when a software related invention was patentable. The court stated that the invention as a whole should be examined. Is the invention in actuality only a mathematical algorithm, such as a computer program designed to convert binary-coded decimal numbers into binary numbers?

\footnotetext{
${ }^{45}$ See The History of Software Patents, Bit Law, available at www.bitlaw.com, last visited 10 July 2004.

${ }^{46}$ See Ibid.
} 
If so, then the invention is unpatentable. However, if the invention utilizes the computer to manipulate numbers that represent concrete, real world values (such as a program that interprets electrocardiograph signals to predict arrhythmia or a program that analyzes seismic measurements), then the invention is a process relating to those real world concepts and is patentable.

In 1995, the USPTO decided it was time to develop guidelines for patent examiners that reflect these recent court decisions. After releasing draft versions of the guidelines for comment, the USPTO adopted guidelines for USPTO examiners to use to determine when a software related invention is statutory and therefore patentable ${ }^{47}$.

On the other hand the European stand on software patenting is confusing and conflicting with the Convention on the Grant of European Patents 1973 popularly known as European Patent Convention (EPC).

Cornish and Liewelyn opined that the exclusion of computer programs "as such" from the scope of the EPC in 1973 reflected a wide spread view in the early computer industry and among researchers in the field. They further said that software was open to protection by trade secrets law, contract and copyright. But, particularly over the last decade, there has been ever growing pressure form the giants of the computer industry to underpin all other IP in the field with patents for inventions ${ }^{48}$.

In the twilight after the dot. Com fireworks of 1997-98, the European Commission proposed to harmonize the law on what software can be patented in Europe. The Commission also relies on the TRIPS requirement to extend patents to all fields of technology. However The EC did not propose any alteration of the basic distinction in the EPC: computer programs as such will remain beyond the scope of patentable subject- matter. The issue remains therefore what this distinction should mean. The basic point lies in the question whether the program invention has a "technical effect" or "technical character". Examples of what constitutes "technical contribution" can be taken from European Patent Office (EPO) case law:

(Koch and Sterzel ${ }^{49}$ : Program governing the operation of a technical device.) A claim to X-ray apparatus controlled by a computer program so as to secure optimal exposure without overloading the X-ray tube was held patentable. It is sufficient to show that "technical means" were involved as well as the mathematical method or algorithm, which was characterised as "non-technical".

The computer programs for which EPO granted patents have directly affected the operation of a piece of equipment. This included a computer itself, making the decisions important where the program was some part of an operating system.

The cases most effectively on the borderline of "technical character" concern claims to the processing of information for some business or informational end,

\footnotetext{
${ }^{47}$ See Ibid F.N.45.

${ }^{48}$ See W Cornish, D Liewelyn, Intellectual Property: Patents, Copyright, Trademarks and Allied Rights, PP. 777-778, Sweet \& Maxwell (2003).

${ }^{49}$ [1988] O.J. EPO 19.
} 
which is useful, but does not result in a "product" in the ordinary sense of a manufacture. It is in this extensive category that the US practice has become much readier to allow patents than in Europe.

Merrill Lynch's Application ${ }^{50}$ (analysis of stock market data.): The application program was for customers in an automated market for shares. It analysed customer's orders to buy and sell against given criteria; if the criteria were satisfied, the transaction was executed automatically. The Court of Appeal held this unpatentable because the operation that resulted was a legal transaction, not a technical effect.

But in a contrast decision EPO granted patent to the famous Amazon 1 Click with USPTO (EPO 902381, US 5960411) ${ }^{51}$. The patent covers the use of Internet "cookies" card every time he buys an item. This idea is evident, as it was one of the aims in mind when the "cookies" system was created ( part of the HTTP standard that is patent free).

What is original in the 1-Click system is the user interface ${ }^{53}$ to buy books in Amazon allows requesting a book with a single click on a button. Till that time, the Internet shops used the metaphor of the shopping cart. It is true that Amazon has been the first bookshop on the Internet that has taken care to make its service easy to use. But here it is difficult to find the so-called technical effect. By applying user interface design, that exists from the $1987^{54}$, to the Internet, Amazon does not become an inventor.

\subsection{Laws Relating to Software Patenting}

\subsubsection{TRIPS Agreement}

Article 27 (1) of the TRIPS Agreement provides for the basis of software patenting. It runs as follows:

"Subject to the provisions of paragraphs 2 and 3, patents shall be available for any invention, whether products or processes, in all fields of technology, provided that they are new, involve an inventive step and are capable of industrial application. ${ }^{55}$ Subject to paragraph 4 of Article 65, paragraph 8 of Article 70 and

\footnotetext{
${ }^{50}$ [1991] R.P.C. 305.

${ }^{51}$ See JS Pascual and RG Fernandez, Software Patents and their impact in Europe P.10, available at http: //joel.editthipage.com/stories/story, last visited 9 July 2004.

52 "Cookies" are a mechanism used to identify users (for example, in order to have each user downloading a web page with different preferences.).

${ }^{53}$ The user interface is the way in which the user interacts with a program. It is composed of different dialog elements (menus, buttons, windows, etc.) that are arranged in a certain way and used with a consistent logic.

${ }^{54}$ For example, the first edition of the book "designing the user interface" by B. Shneiderman, published in 1987, explains how to design an application user interface starting for the functionality. Using this book's method, the 1-Click idea is evident.

${ }^{55}$ [TRIPS Agreement note] For the purposes of this Article, the terms "inventive step" and "capable of industrial application" may be deemed by a Member to be synonymous with the terms "non-obvious" and "useful" respectively.
} 
paragraph 3 of this Article, patents shall be available and patent rights enjoyable without discrimination as to the place of invention, the field of technology and whether products are imported or locally produced." 56

According to Article 27 of the TRIPS Agreement Members may exclude from patentability inventions to protect ordre public or morality, including to protect human, animal or plant life or health or to avoid serious prejudice to the environment subject to the condition mentioned therein. Members may also exclude from patentability:

(a) diagnostic, therapeutic and surgical methods for the treatment of human or animals;

(b) plants and animals other than micro-organisms, and essentially biological processes for the production of plants or animals other than non-biological and microbiological process.

From the aforementioned provisions supporters of software patenting find their basis of argument that process related computer programs are patentable.

But the German Federal Patent Court exclusively refutes the fallacy of TRIPS. It held that:

\begin{abstract}
The Treaty on Trade Related Aspects of Intellectual Property Rights (TRIPs) does not entail any different judgment of patentability. Independently of the question as to in what form - directly or indirectly - the TRIPs treaty is applicable here, the application of Art 27 TRIPs would not lead to any extension of patentability here. The wording, according to which patents shall be available for inventions in all fields of technology, merely confirms the dominating view of german patent jurisprudence, according to which the concept of technology (Technik) constitutes the only usable criterion for delimiting inventions against other kinds of intellectual achievements, and therefore technicity is a precondition for patentability (the "Logikverifikation" decision of the Federal Court of Justice (BGH) sees Art 27 TRIPs as "posterior confirmation" of this jurisprudence). The exclusion provision of Art 52 (2) and (3) EPC can also not be construed to be in conflict with Art 27 TRIPs, since it is based on the notion of lacking technical character of the excluded items.
\end{abstract}

The Federal Patent Court here refers to the Dispositions programms doctrine, according to which the presence or not of controllable forces of nature in the solution of the problem is the only usable criterion for delimiting the realm of patentable inventions ${ }^{57}$.

\footnotetext{
${ }^{56}$ See Article 27 (1) of Agreement on Trade-Related Aspects of Intellectual Property Rights (TRIPS Agreement) (1994), WIPO Publication No. 223(E).

${ }^{57}$ See swpat.ffii.org/analysis/trips/index.en.html, last visited 11 July 2004.
} 


\subsubsection{The US Law}

\section{a. Codified Law and Interpretation}

The founders of the United States provided in the Constitution that "Congress shall have the power...to promote the progress of science and useful arts, by securing for limited times to authors and inventors the exclusive right to their respective writings and discoveries. ${ }^{58}$ A patent is the grant from the United States government to the owner of an invention to exclude all others from making, using or selling the invention for a limited time. In exchange for the patent rights, the inventor is required to disclose the invention in enough detail to allow other people to use the invention after the monopoly expires and to learn from the invention to build on its ideas. ${ }^{59}$ Thus, the patent system was founded to promote technological development by providing incentive to developers of new products through enabling them to prevent others from "stealing their ideas" through profiting without spending the necessary research time and money.

The Patent Act is broad and general in its language describing the proper subject matter for a patent:

"Whoever invents or discovers any new and useful process, machine, manufacture, or composition of matter, or any new and useful improvement thereof, may obtain a patent therefor, subject to the conditions and requirements of this title.",60

However, not all "inventions" are patentable; "excluded from such patent protection are laws of nature, natural phenomena, and abstract ideas." 61 "An idea in and of itself is not patentable." 62

As cast, $\S 101$ defines four categories of inventions that Congress deemed to be the appropriate subject matter of a patent; namely, processes, machines, manufactures and compositions of matter. The latter three categories define "things" while the first category defines "actions" (i.e., inventions that consist of a series of steps or acts to be performed). ${ }^{63}$

Federal courts have held that $\S 101$ does have certain limits. First, the phrase "anything under the sun that is made by man" is limited by the text of $\S 101$, meaning that one may only patent something that is a machine, manufacture, composition of matter or a process. ${ }^{64}$ Second, $\S 101$ requires

\footnotetext{
${ }^{58}$ See U.S. Const. Art. $1, \S 8$, cl. 8.

${ }^{59}$ For additional discussion, see, Note, Patent Policy $=$ Protection of Inventor's Rights $=$ The patentability of Mathematical Algorithms, 17 University of Dayton Law Review 181 at 182 (Fall 1992).

${ }^{60}$ See 35 U.S.C. $\$ 101$.

${ }^{61}$ Diamond v. Diehr, 450 U.S. 175 at 185 (1981).

${ }^{62}$ Rubber-Tip Pencil Co. v. Howard, 20 Wall. 498 at 507 (1874).

63 See 35 U.S.C. $§ 100(\mathrm{~b})$ ("The term 'process' means process, art, or method, and includes a new use of a known process, machine, manufacture, composition of matter, or material.").
}

64 E.g., Alappat, 33 F.3d at 1542, 31 USPQ2d at 1556; In re Warmerdam, 33 F.3d 1354, 1358, 31 USPQ2d 1754, 1757 (Fed. Cir. 1994). 
that the subject matter sought to be patented be a "useful" invention. Accordingly, a complete definition of the scope of $\S 101$, reflecting Congressional intent, is that any new and useful process, machine, manufacture or composition of matter under the sun that is made by man is the proper subject matter of a patent. Subject matter not within one of the four statutory invention categories or which is not "useful" in a patent sense is, accordingly, not eligible to be patented.

The subject matter courts have found to be outside the four statutory categories of invention is limited to abstract ideas, laws of nature and natural phenomena. While this is easily stated, determining whether an applicant is seeking to patent an abstract idea, a law of nature or a natural phenomenon has proven to be challenging. These three exclusions recognize that subject matter that is not a practical application or use of an idea, a law of nature or a natural phenomenon is not patentable. ${ }^{65}$

Courts have expressed a concern over "preemption" of ideas, laws of nature or natural phenomena. ${ }^{66}$ The concern over preemption serves to bolster and justify the prohibition against the patenting of such subject matter. In fact, such concerns are only relevant to claiming a scientific truth or principle. Thus, a claim to an "abstract idea" is non-statutory because it does not represent a practical application of the idea, not because it would preempt the idea.

Although most software related inventions are now statutory under the USPTO's Final Computer Related Examination Guidelines of 1996, it is important to be remembered that "software" as a class is not patentable. What is patentable are "processes" and "machines". Thus the guidelines are framed so as to assist in determining when computer related inventions are patentable processes or machines.

According to the new guidelines, computer programs that have traditionally been held to be statutory will continue to be statutory without further analysis. These "safe harbor" inventions include two types of inventions:

65 See, e.g., Rubber-Tip Pencil Co. v. Howard, 87 U.S. 498, 507 (1874) ("idea of itself is not patentable, but a new device by which it may be made practically useful is"); Mackay Radio \& Telegraph Co. v. Radio Corp. of America, 306 U.S. 86, 94 (1939) ("While a scientific truth, or the mathematical expression of it, is not patentable invention, a novel and useful structure created with the aid of knowledge of scientific truth may be."); Warmerdam, 33 F.3d at 1360, 31 USPQ2d at 1759 ("steps of 'locating' a medial axis, and 'creating' a bubble hierarchy . . . describe nothing more than the manipulation of basic mathematical constructs, the paradigmatic 'abstract idea"').

66 The concern over preemption was expressed as early as 1852 . See Le Roy v. Tatham, 55 U.S. 156,175 (1852) ("A principle, in the abstract, is a fundamental truth; an original cause; a motive; these cannot be patented, as no one can claim in either of them an exclusive right."); Funk Brothers Seed Co. v. Kalo Inoculant Co., 333 U.S. 127, 132, 76 USPQ 280, 282 (1948) (combination of six species of bacteria held to be non-statutory subject matter). 
Those having "significant post solution activity", meaning that the software program is used to control something external to the software routine (such as curing rubber), and

those having "pre-computer process activity", meaning software programs that manipulate numbers representing concrete, real world values (such as electrocardiograph signals and seismic measurements.

In addition to these safe harbor inventions, a computer related invention will be statutory if it is claimed in connection with a specific machine or product. This can be accomplished by defining specific code segments or routines in the patent application, or by claiming the invention in connection with a specific type of computer or memory structure. What is not important is the type of computer program involved. Thus, while it is clear that a program designed to improve communication speed over a modem is statutory subject matter, it is equally clear that a graphics program, a spreadsheet, and a word processing program are statutory when properly claimed.

\title{
b. Case Law
}

\section{i. Gottschalk V. Benson}

Amazingly enough, although computer programs have been developed for many decades, the United States Supreme Court did not see a case that raised the issue of whether a computer program is patentable until $1972 .{ }^{67}$ In that case, the Court reviewed a patent application describing an invention as a method for converting binary-coded decimal numerals into pure binary numerals in a general purpose digital computer. Although the Court found that the invention was not patentable, it stated that this decision did not preclude ever finding a computer program patentable. $^{68}$

In the 1972 United States Supreme Court case, Gottschalk v. Benson, ${ }^{69}$ the Court framed the issue as: "The question is whether the method described and claimed is a 'process' within the meaning of the Patent Act." ${ }^{70}$ The Court went on to describe the claimed invention:

\begin{abstract}
"The patent sought is on a method of programming a general-purpose digital computer to convert signals from binary-coded decimal form into pure binary form. A procedure for solving a given type of mathematical problem is known as an 'algorithm.' The procedures set forth in the present claims are of that kind; that is to say, they are a generalized formulation for programs to solve mathematical problems of converting one form of numerical representation to another. From the generic formulation, programs may be developed as specific applications."71
\end{abstract}

\section{ii. Diamond V. Diehr}

Even by 1980, the USPTO was still trying to argue that an invention that claimed a stored program in a computer was not patentable. The United States Supreme

\footnotetext{
${ }^{67}$ See Gottschalk v. Benson, 409 U.S. 63 (1972).

${ }^{68}$ See Gottschalk v. Benson, 409 U.S. at 65.

${ }^{69} 409$ U.S. 63 (1972).

${ }^{70} 409$ U.S. at 64.

${ }^{71} 404$ U.S. 65.
} 
Court, in a case of Diamond v. Diehr, reviewed a patent application for molding raw, uncured synthetic rubber into cured precision products including constant measurement of actual temperature inside the mold during the curing process to recalculate the cure time (by a computer program). ${ }^{72}$ The USPTO examiner had rejected the claims (in 1976) on the basis that Benson precluded patentability of the steps of the process that used a computer program, and the remainder of the steps were already known in the industry. ${ }^{73}$ The appellate Court (CCPA) reversed the finding, but the USPTO Commissioner requested the United States Supreme Court to review the decision in 1980. The United States Supreme Court addressed only the issue of whether a process employing a mathematical algorithm is patentable. The Court found that the invention used a mathematical algorithm, but as a whole, the invention directed itself to the process of molding rubber and was thus patentable.

\section{iii. Recent Federal Circuit Decisions}

More recently, the Federal Circuit has issued several cases dealing with the question of whether various software-related inventions fall outside the areas of proper subject matter as unpatentable mathematical algorithms. In the decision of In re Schrader ${ }^{74}$ the court found a competitive bidding method to include a mathematical algorithm which rendered the claims unpatentable. The court found that even though no mathematical formula was explicitly stated in the claims, the method implied the use of a simple summing method without physical elements or process steps.

However, after a very divided court issued the case of In re Alappat, ${ }^{75}$ the future appeared brighter for the viability of broad computer software patents. The claims of that upheld patent were directed toward a "machine" for smoothing waveforms for an oscilloscope. Since the claims were directed toward a machine, including elements described in a "means-plus-function" format, it appeared that claim drafting techniques would be the answer to making software-related inventions patentable subject matter. The case pointed out that although specific hardware structures had been disclosed in the specification, (ALU, ROM, shift registers) the claim at issue would also read on a general purpose computer programmed to carry out the invention. ${ }^{76}$

The case of In re Warmerdam ${ }^{77}$ seemed to support this view since the court found the robotic collision avoidance system "method" and "data structure" claims of that patent to be unpatentable subject matter, yet upheld the claim directed toward a machine including memory generated according to the unpatentable method. Another interesting note regarding that case is that the court avoided the issue of determining a definition for a "mathematical algorithm", instead finding the issue to be whether the method for generating a data structure representing the shape of

\footnotetext{
${ }^{72}$ Gottschalk v. Benson, 409 U.S. at 65.

${ }^{73} 450$ U.S. at 180-181.

${ }^{74}$ In re Schrader, 22 F.3d 290, 30 U.S.P.Q.2d 1455 (Fed. Cir. 1994).

${ }^{75}$ In re Alappat, 33 F.3d 1526, 31 U.S.P.Q.2d 1545 (Fed. Cir. 1994).

${ }^{76} 31$ U.S.P.Q.2d at 1558. "Consequently, a computer operating pursuant to software may represent patentable subject matter, provided, of course, that the claimed subject matter meets all of the other requirements of Title 35 . In any case, a computer, like a rasterizer, is apparatus not mathematics."

${ }^{77}$ In re Warmerdam, 33 F.3d 1354, 31 U.S.P.Q.2d 1754 (Fed. Cir. 1994).
} 
a physical object was "a process that goes beyond simply manipulating 'abstract ideas' or 'natural phenomena"'. ${ }^{78}$

Later in the year, the Federal Circuit decided the case of In re Lowry ${ }^{79}$ to reverse a decision by the Board of Patent Appeals and Interferences to find a claim to a "memory" with a particular "data structure" for organizing memory to be patentable subject matter. However, rather than presenting a direct argument under 35 U.S.C. $\S 101$, the Board argued that the data structure was analogous to printed matter, and thus obvious under 35 U.S.C. $\S \S 102$ and 103. The court disagreed and found the "memory" claims to be patentable.

Finally, the most recent and troubling case addressing the patentability of software-related inventions is the case of In re Trovato. ${ }^{80}$ In this case, the court found both method and machine claims directed toward planning a path for an object to follow in a physical task space to be unpatentable subject matter. The court upheld application of the Freeman-Walter-Abele ${ }^{81}$ test and found that although the claims did not express the mathematical algorithm in terms of a mathematical formula, the court re-stated that words in a claim operating on data can serve the same purpose as a formula.

Of particular importance to the court was the lack of disclosed structure in the specification, prompting the court to find the machine claims to be drafted in "illusory apparatus format." 82 Finally, the court noted "Trovato does not claim to have invented a new kind of computer which the recited mathematical algorithm controls. ${ }^{83}$ Nor do they claim that the recited mathematical algorithm has been combined with a new memory controlling a computer known to the art." ${ }^{84}$

In conclusion, In re Trovato seems to erase the perception created by the court in In re Warmerdam that claim drafting techniques will provide the entire answer for the persistent subject matter problems for software-related inventions. Instead, future specifications will apparently be scrutinized much more closely for detailed structural disclosure, and mathematical algorithms will apparently be found to exist in more unlikely locations.

\section{iv. The Patentability Spectrum}

The case law to date indicates that the patentability of software-related inventions can be described by examining the spectrum of those inventions; the ends of the spectrum are clear, but the lines in the middle are very fuzzy:

\footnotetext{
7831 U.S.P.Q.2d at 1759.

${ }^{79}$ In re Lowry, 32 U.S.P.Q.2d 1031 (Fed. Cir. 1994).

${ }^{80}$ In re Trovato, 33 U.S.P.Q.2d 1194 (Fed. Cir. 1994).

81 "It is first determined whether a mathematical algorithm is recited directly or indirectly in the claim. If so, it is next determined whether the claimed invention as a whole is no more than the algorithm itself; that is, whether the claim is directed to a mathematical algorithm that is not applied to or limited by physical elements or process steps."

Arrhythmia, 958 F.2d at 1058, 22 U.S.P.Q.2d at 1037.

8233 U.S.P.Q.2d at 1199.

${ }^{83}$ This is an interesting comment in light of the court's previous statement in In re Alappat that "a general purpose computer in effect becomes a special purpose computer once it is programmed to perform particular functions pursuant to instructions from program software." Id. at 1558.

${ }^{84}$ This final comment is apparently a reference to the court's earlier decision in In re Lowry.
} 
Mathematical algorithms found not to be patentable by themselves.

a computer software algorithm for converting from binary-coded decimal numerals to pure binary numerals (Benson)

formula for computing an updated alarm limit during a catalytic conversion process (Flook)

an improved mathematical equation for interpreting seismic waves (In re Walter)

a competitive bidding method where simply summing was found to be a mathematical algorithm (In re Schrader)

a method and a data structure for collision avoidance (In re Warmerdam)

a method and a machine for planning object movement (In re Trovato)

Algorithms that are expressed as mathematical formulas found not to be patentable by themselves, and those algorithms which appear to replicate human decision-making skills found not to be patentable:

a process and apparatus for testing a complex system and analyzing the results (for use in medical diagnosis), using functions of $\mathrm{K}$ elements (any arbitrary subdivision of the system such as neuropathways in the human nervous system) (In re Meyer).

a process for determining "abnormalities" in a complex system (In re Grams)

Computer algorithms unrelated to mathematics found to be patentable:

computer program for the translation of natural languages (In re Toma)

computer program for executing several equations regardless of the order of their input (In re Pardo)

Computer algorithms that pertain to the operations of the hardware found to be patentable:

system software (Chatfield)

firmware (Bradley)

algorithm for typesetting alphanumeric equations (Freeman)

waveform smoothing algorithm for oscilloscope (In re Alappat)

a machine with a collision avoidance memory (In re Warmerdam)

a memory with data structure for organizing data (In re Lowry)

Processes or apparatus that use computer programs as a component of the overall invention found to be patentable:

rubber curing process (Diehr)

improved CAT scan procedure (Abele) 
apparatus for voice pattern recognition (Iwahashi)

method for analyzing electrocardiograph signals (Arrhythmia)

Despite the various analyses by the Courts that result in this categorization of the cases, it is also clear that some of these cases have differences without real distinctions. The Arrhythmia case (1992) appears to be not different in real principle from the Walter case (1980)(the process of analyzing electrocardiograph signals is patentable although the process of analyzing seismic wave signals is not patentable). Further, it is difficult to really say that the "mathematical algorithms" in the two systems analysis cases reflect a natural truth (like the "law of gravity"), as the patent application claims read more on a methodology of estimating probabilities. Accordingly, it appears the analysis of "algorithms" and "data structures" needs further refinement as the Courts better understand the function and result of computer programs.

\subsubsection{European Law}

\section{a. European Patent Convention and Interpretation}

According to the general requirements cf. article 52(1)-(3) of the EPC, which are reproduced in essence in Member States' patent laws, all patentable inventions must be new, involve an inventive step and be capable of industrial application cf. Article 52(1).

Under Art. 52(2) of the EPC, programs for computers are defined as not being inventions and are thus excluded from patentability. The Boards of Appeal of the EPO have held that it is fundamental to all inventions that they have a technical character. Similarly, Article 27(1) of the TRIPS Agreement confirms that patents shall be available for inventions in all fields of technology. Accordingly, the EPO Boards of Appeal and some courts of the Member States have held that "computer-implemented inventions" can be considered as patentable when they have a technical character, i.e. when they belong to a field of technology. Computer-implemented inventions which meet this condition are not considered to fall under the exclusion in Article 52(2) as they are considered not to relate to "programs for computers "as such""'. In fact, the exclusion has been interpreted by the Boards of Appeal of the EPO as relating to those "computer-implemented inventions" which "have no technical character".

With regard to what computer-implemented inventions can be said to have a "technical character" the conclusion to be drawn from the recent Controlling pension benefits system case is that all programs when run in a computer are by definition technical (because a computer is a machine), and so are able to pass this basic hurdle of being an "invention".

Similar considerations have been applied by the EPO Boards of Appeal to the other non-inventions listed in Art. 52(2), for instance to "methods for doing business", "presentation of information", or "aesthetic creations". This means that these non-inventions have equally been held to be patentable when they "have a technical character". 
With regard to the representation of the (non-)invention in the patent claims, the Board held, in Computer program product I \& II that if a program on a carrier has the potential to produce a technical effect when loaded and run on a computer, such a program claimed by itself should not be excluded from patentability. This has been interpreted as meaning that it should be allowable to claim such a program by itself or as a record on a carrier or in the form of a signal (e.g. stored as a file on a disk or transmitted across the internet).

\section{b. Case Law}

\section{(i) Vicom $^{85}$}

This is the first of a series of cases heard by the Technical Board of Appeal, which has shown a remarkable degree of adherence to the post-1985 European Patent Office guidelines. The matter concerned was a patent application relating to methods and apparati for improving the quality and speed of digital image processing. The image appearing on the face of an electronic display screen was caused by electrical signal represented by a set of numbers inside the memory of a computer. The processing and manipulation of the image required corresponding processing and manipulation of numbers representing the image. A lot of calculations would need to be performed in the process according to a mathematical algorithm. The "invention" in this case was in fact a new mathematical algorithm for the manipulation of these numbers. The new algorithm allowed the necessary calculations to be done in a much speedier and more accurate way in comparison with using a traditional algorithm. The Technical Board resolved to allow the patent application even though it was in truth a patent application for a mathematical algorithm.

The Technical Board characterised the invention as a technical process. It arrived at this conclusion by looking at the effects of the invention. Since the effects were manifested as changes in physical entity (an image), the Board regarded such effects as technical and therefore the process that brought about such effects as a technical process within the scope of patentability. Without directly defining the meaning of "technical", the Board seemed to have characterised a technical process as one, which would bring about changes in a physical entity. ${ }^{86}$

A number of important points may be observed from the Board's judgment as follows:

A patentable invention is one which is technical in nature;

. A mathematical algorithm is in effect patentable if it is incorporated within a technical process;

. A technical process is one which produces technical results;

. Changes in a physical entity constitute a technical result;

${ }^{85}$ T208/84, [1987] 2 EPOR 74.

${ }^{86}$ See Dr. Matthew Lee, 'Patentability of Software-Related Inventions' P. 12, available at www.is.cityu.edu.hk/Research/workingpapers/paper/9420.pdf, last visited 28 August 2004. 
An image is a physical entity.

\section{(ii) IBM/Semantics ${ }^{87}$}

In this case IBM sought to patent a system for automatically generating a list of expressions semantically related to an input linguistic expression and a method for displaying such a list of expressions. The system was in fact a fairly straightforward implementation of a semantic network. A semantic network is in essence a network of conceptual items linked by semantic relationships. For example, "Paul likes Mary" is a semantic expression containing two conceptual items, viz., Paul and Mary, semantically related by the link "likes". Supposing there were other similar expressions such as "Paul likes Janice", "Paul likes Rebecca", etc., then given a partial semantic expression such as "Paul likes", the system would be able to display a list containing the conceptual items "Mary, Janice, Rebecca, etc.". It is obvious that this type of system is useful in database applications. The IBM system involved two memories, the first holding a vocabulary of linguistic concepts and the second holding all the semantic links. Associated with the linguistic concepts in the first memory were stored the addresses of the related semantic links in the second memory. Associated with the semantic links in the second memory were also stored the addresses of all related linguistic concepts in the first memory. It was a sort of "dual-referencing" set-up. In operation, an input expression was compared with the contents of the first memory to find the corresponding semantic link address in the second memory; from the semantic link so identified in the second memory, the addresses of all the other related linguistic concepts in the first memory could be found. From these addresses, all the related linguistic concepts could be gathered and displayed. In refusing the patent application the Board made the following comments:

"...semantic relationship is basically not of a technical nature but a matter of the meaning of those expressions, that is, of their abstract linguistic information content; it does not relate to any physical entity... [as to the contributions made by the features of the claim] these features show the following sequence of functions... these functions as such are all conventional: storing data; comparing input data with an index for finding an address location; storing the address; accessing with it a memory; decoding data as an address for accessing another memory; displaying the addressed data... It follows that the functional features of the individual system elements relate to the linguistic evaluation, on the basis of a linguistic relationship, of input linguistic data, for the purposes of displaying a linguistic result, the actual processing involving only conventional techniques... No contribution is therefore made in a field outside linguistics nor outside the field of conventional computer performance".

The Board observed that the invention as a whole did not relate to any physical entity. But before rejecting the application outright there and then the Board continued to look at the contributions made by the individual elements of the claim and then concluded that these contributions are either linguistic (which is not a patentable subject-matter) or conventional (i.e. no invention was made). It seems to indicate that the lack of any relationship to a physical entity in itself is not fatal with regard to a patent application. The Board went on to deduce that the application was in effect a patent application for a computer program as such:

\footnotetext{
${ }^{87}$ T52/85 [1989] 8 EPOR 454.
} 
"Moreover, the functioning of the computer is... under the control of an appropriate program. No contribution is consequently made in a field outside computer programming...".

IBM also argued that the invention was a technical solution to a technical problem. However, the Board took the view that the finding of semanticallyrelated linguistic expressions had to do with the linguistic significance of words and was thus a linguistic problem and not a technical problem (again, without first defining the meaning of "technical" and "linguistic"). No technical problem concerning the computer was to be solved. As regards the solution, the Board regarded what's claimed as a straight-forward automation of a linguistic problem producing no technical effect. The computer was a standard, general-purpose one which did not operate in any unusual way. They accordingly held the claim as one for unpatentable subject-matter. This case differs from Vicom and Kock \& Sterzel in that no physical entity or effect outside the computer is involved, even though in all three cases the essence of the inventions are algorithms residing in computer programs. $^{88}$

\section{(iii) IBM/Network ${ }^{89}$}

The Technical Board considered a claim for procedures to enable a network of computers to maintain concurrent and automatic connection between a computer of the network and for more than one application program residing on different computers on the network. The procedures would also provide for simultaneous online access to and processing of more than one data file residing on different computers on the network. These procedures were implemented using a network supervisory computer running a computer program embedding the procedures. Thus, the claim had (as the basis of the invention) a computer program, but it related to a series of computers connected together. In allowing the claim, the Board made the following observations:

"The Board holds the view that an invention relating to the co-ordination and control of the internal communication between programs and data files held at different processors in a data processing system having a plurality of interconnected data processors in a telecommunication network, and the features of which are not concerned with the nature of the data and the way in

which the particular application program operates on them, is to be regarded as solving a problem which is essentially technical. Such an invention is therefore to be regarded as an invention within the meaning of Art.52(1) EPC". 90

\section{(iv) DISCUSSIONS AND EMERGING TRENDS}

From the examination of the above cases, a number of important trends may be identified. First, there is now a general congruence in attitude between the English Courts and the European Patent Office towards the scope and nature of

\footnotetext{
${ }^{88}$ See Dr. Matthew Lee, 'Patentability of Software-Related Inventions' PP. 15-16, available at www.is.cityu.edu.hk/Research/workingpapers/paper/9420.pdf, last visited 28 August 2004.

${ }^{89}$ T6/83, [1990] EPOR 91.

${ }^{90}$ See Ibid F.N. 88, PP. 17-18.
} 
patentability in the area of software-related inventions. Secondly, in determining the patentability of a claim, the emphasis is now firmly on looking at the invention as a whole. Previously (prior to 1985), the emphasis was on either excluding the nonpatentable ingredients of an invention for examination or isolating the novel element for examination. There is now no need to break up an invention into its constituent elements in the examination process. If an invention as a whole can be characterised as technical then it qualifies as a patentable subject-matter. The key to deciding whether an invention has a technical character is to look at the effect, result, or contribution that the invention makes relative to the prior art. If the effect, result or contribution made is physical in nature or involves changes in physical entities then it is likely (but not necessary ${ }^{91}$ ) that the invention has a technical character and hence is patentable. Thirdly, substance has started to triumph over form. If the substance of a claim is unpatentable then it is now more unlikely than before that the situation can be improved by changing the form of the claim. This is perhaps best illustrated by the case of Gale's Application $^{92}$ where the substance of the claim was a mathematical algorithm but the form of the claim was skillfully drafted so as to relate not to an algorithm but to a radically different entity, namely, the structure of a physical product (the ROM chip). This handy work on drafting did not manage to fool the Court of Appeal however. ${ }^{93}$

\subsection{Software Patent V. Copyright}

\section{a. Argument for Software Patenting}

(i) Algorithms, programs and computer languages are the three main components of software ${ }^{94}$ technology. An algorithm specifies (using a procedural or

\footnotetext{
${ }^{91}$ In the matter of Application No.8700138 by Hitachi Limited, The UK Patent Office, 22 May 1990.

92 Gale's Application, CA transcript, 13 December 1990, also in RE GALE, FT Law Reports, 18 December 1990.

${ }^{93}$ See Dr. Matthew Lee, 'Patentability of Software-Related Inventions' P.35, available at www.is.cityu.edu.hk/Research/workingpapers/paper/9420.pdf, last visited 28 August 2004.

94 The term "software" usually has wider connotations which also include operating procedures and

associated documentation (such as user and reference manuals) concerning the use of a computerised information system.
} 
mathematical notation) a conditional sequence of steps or operations for solving a class of problems. As such algorithms are abstract procedural entities for accomplishing certain processing goals. Programs are coded instructions for directing and controlling the operations of the computer hardware. These coded instructions are written in specific computer languages that the computer can understand. In a software technology setting, algorithms are expressed by programs which are written in specific computer languages. Computer languages in the main are not afforded any legal protection under intellectual property law. In any case they are invariably in the public domain. Algorithms, whether mathematical or otherwise, are per se abstract information relating to mental activities which do not all within the scope of protection afforded by intellectual property law in general. However, it is the embodiment of algorithms within computer programs that gives rise to tangible economic value. Through such programs, computers can perform useful operations (e.g. controlling a wielding robot) which result in tangible economic benefits. It is therefore reasonable that programs form the focus of attention with regard to the legal protection of software technology. Software technology is at least as expensive to develop as hardware technology but very inexpensive to copy. With the rapidly increasing economic and commercial prominence of software technology it is understandable that software developers are now becoming particularly keen on finding legal frameworks to protect their investments. It is now quite clear that the main mode of legal protection for software technology is copyright ${ }^{95}$, although patents and contracts also play some roles in protecting different aspects of the technology. However, the more absolute nature of protection brought about by patents offers significant attractions to developers seeking to maximise the degree of legal protection for their investment. Further, copyright is intended to protect only the expression of an invention but not the ideas (or application of ideas) underpinning it. In many cases of software invention, the underpinning applied ideas are the truly inventive elements whereas their concrete expression in the form of program implementation is comparatively routine and trivial.

(ii) A study conducted by the Intellectual Property Institute in London has found that the patentability of computer-related inventions has helped the growth of computer program-related industries in the US, in particular the

\footnotetext{
${ }^{95}$ e.g. The Copyrights, Designs, and Patents Act 1988 in the UK has explicitly stipulated that computer

programs are protected under copyright law as a species of literary work.
} 
growth of small and medium enterprises and independent software developers into sizeable indeed major companies" 96.

(iii) Patents play an important role in ensuring the protection of technical inventions in general. The basic principle underlying the patent system has proven its efficiency with respect to all kinds of inventions for which patent protection has thus far been afforded in the Member States of the European Community. Patents act as an incentive to invest the necessary time and capital and it stimulates employment. Society at large also reaps benefits from the disclosure of the invention which brings about technological progress upon which other inventors can build ${ }^{97}$.

(iv) The current legal situation regarding patent protection in the field of computer-implemented inventions is ambiguous, and thus lacks legal certainty. In fact, computer programs "as such" are excluded from patentability by Member States' patent laws and the European Patent Convention (EPC) but thousands of patents for computer-implemented inventions have been granted by the European Patent Office (EPO) and by national patent offices. The EPO alone accounts for more than 20,000 of them. Many of these patents are in the core areas of information technology, i.e. digital data processing, data recognition, representation and storage. Others are being granted in other technical areas such as automotive and mechanical engineering, e.g. for program-controlled processors. While the statutory provisions setting out the conditions for granting such patents are similar, their application in the case law and the administrative practices of Member States is divergent. There are differences, in particular, between the case law of the Boards of Appeal of the European Patent Office and the courts of Member States. Thus, a computer-implemented invention may be protected in one Member State but not in another one, which has direct and negative effects on the proper functioning of the internal market. The amended EU Software Directive addresses this situation by harmonising national patent laws with respect to the patentability of computerimplemented inventions and by making the conditions of patentability more transparent ${ }^{98}$.

(v) To create a level playing field regarding the conditions for protecting computer-implemented inventions between Europe and the U.S., it could have been considered desirable to widen the scope of protection and bring European patent law in this field more in line with the U.S. law. One could have conceived, in particular, to allow for the patentability of computer-implemented business methods. The difference between the U.S. and Europe and between the U.S. and Japan is that in Europe there has to be a technical contribution provided by the invention. In Japan there is a doctrine, which has traditionally been interpreted in a similar way: the invention has to be a highly advanced creation of technical ideas by which a law of nature is utilised. In the U.S., the invention must simply

\footnotetext{
${ }^{96}$ See IPI 200: The Economic Impact of Patentability of Computer Programs, available at swpat.ffii.org, last visited 14 July 2004.

${ }_{97}$ See at swpat.ffii.org/papers/eubsa-swpat0202/intro/index.en.html/, last visited 14 July 2004.

${ }^{98}$ See at swpat.ffii.org/papers/eubsa-swpat0202/pref/eubsa-fnot, last visited 14 July 2004.
} 
be within the technological arts and no technological contribution is needed. The mere fact that the invention uses a computer or software makes it become part of the technological arts if it also provides a "useful, concrete and tangible result". That the U.S. does not require the invention to provide a technical contribution means that the restrictions on patenting of business methods (apart from the requirements of novelty and inventive step) are negligible ${ }^{99}$.

\section{b. Argument for Copyright}

(i) Notwithstanding the issuance of software patents, many more right holders rely on copyright protection for computer software. The dynamics of protection under copyright and patent are quite different. Copyright protection is automatic and vests upon the creation of the work at the time the program is written. Depending on the provisions of the relevant national law, such protection may last for the life of the author plus 50 years (now 70 years under many national laws, such as the European Community member States and the United States of America). Patent protection is subject to strict procedures for the perfection of rights, such as examination, public disclosure, and maintenance fees. The term of protection for patents is more limited: 20 years from the date of filing. Patent enforcement, however, is more extensive than that provided under copyright law ${ }^{100}$.

(i) Patents have traditionally been applied as a regulation instrument for the stimulation of investment in the field of technical invention. The basic principles underlying the patent system continue to be highly controversial among economists, and the question whether the patent system as it stands in the member states of the European Community today is beneficial or detrimental to the economy, needs to be asked and studied without prejudice. In theory, patents should act as an incentive to invest the necessary time and capital and thereby to stimulate employment in research and development activities. Society at large should also reap benefits from the disclosure of the invention, which should bring about technological progress upon which other inventors can build. Fritz Machlup as well as most respected economists have found that this supposed positive effect of the patent system is likely to be outweighed by negative effects. They have therefore advised great caution in formulating policies concerning the scope and conditions of patentability. One of the results of such caution has been the exclusion of software and, in general, purely mental achievements from patentability in the European Patent Convention of $1973^{101}$.

(ii) Patents are being granted on trivial, indeed old, ideas and that consideration of such patents let alone attacking such patents is a major burden, particularly on SME and independent software developers.

\footnotetext{
99 See Ibid.

${ }^{100}$ See Intellectual Property A Power Tool for Economic Growth, PP. 210-211, WIPO, available at www.wipo.int/about_wipo/en/dgo/wipo_pub_888/index_wipo_pub_888.html, last visited 18 July 2004.

${ }^{101}$ See Ibid at P. 34.
} 
(iii) Patents may strengthen the market position of the big players.

(iv) The computer program related industries are examples of industries where incremental innovation occurs and that there are serious concerns whether, in such industries, patents are welfare enhancing.

(v) The high probability of accidental patent infringement may force software companies to go to greater lengths hide their source code, as open source would make suing them easier. This has severe consequences for security and maintenance. For security because life and public health depend on certain applications, and those making use of them cannot allow the risk of not knowing exactly how they work. On maintenance as most times a client needs to modify a program to fulfill a requirement that was not anticipated by the program designer ${ }^{102}$.

\subsection{Patent and Copyright Protection Complementary}

A patent protects an invention as delimited by the patent claims, which determine the extent of the protection conferred. Thus, the holder of a patent for a computer-implemented invention has the right to prevent third parties from using any software, which implements his invention (as defined by the patent claims). This principle holds even though various ways might be found to achieve this using programs whose source or object code is different from each other and which might be protected in parallel by independent copyrights, which would not mutually infringe each other ${ }^{103}$.

On the other hand, for the purposes of Directive 91/250/EEC on the legal protection of computer programs, copyright protection is accorded to the particular expression in any form of a computer program, while ideas and principles, which underlie any element of a computer program, including those, which underlie its interfaces, are not protected. A computer program will be accorded copyright protection where the form of expression is original in the sense of being the author's own intellectual creation. In practice, this means that copyright would subsist in the expression in any form of the source code or the object code but would not subsist in the underlying ideas and principles of the source code or object code of a program. Copyright prohibits a substantial copy of the source code or object code but does not prevent the many possible alternate ways to express the same ideas and principles in different source or object code. It also does not protect against development of an identical or substantially identical program without the knowledge of an existing copyright.

Accordingly, legal protection may exist in a complementary manner in respect of the same program both by patent and by copyright law. The protection may be cumulative in the sense that an act involving exploitation

\footnotetext{
${ }^{102}$ J S Pascual, R G Fernandez, Software patents and their impact in Europe, P.6, available at joel.editthispage.com/stories/storyReader\$17, last visited 15 July 2004.

${ }^{103}$ See BSA/CEC Advocative Preface, available at swpat.ffii.org/papers/eubsaswpat0202/pref/index.en.html, last visited 15 July 2004.
} 
of a particular program may infringe both the copyright in the code and a patent whose claims cover the underlying ideas and principles.

Directive 91/250/EEC includes specific provisions (Articles 5 and 6) to the effect that copyright in a computer program is not infringed by the doing of acts under certain circumstances which would otherwise constitute infringement. These exceptions include acts done for the purposes of studying the ideas and principles underlying a program and the reproduction or translation of code if necessary for the achievement of the interoperability of an independently created computer program. It is also specified that the making of a back-up copy by a lawful user cannot be prevented. Such provisions are justified and necessary in the context of copyright law because copyright confers the absolute right to prevent the making of copies of a protected work. All the acts mentioned involve making copies and would therefore infringe in the absence of any exception. On the other hand, Member States' patent laws, while not fully harmonised, do not in general extend to acts done privately and for non-commercial purposes, or to acts carried out for experimental purposes related to the subject-matter of the invention. Nor is it likely that the making of a back-up copy in the context of the authorised exploitation of a patent covering a programmed computer or the execution of a program could be construed as an infringement. Thus, because of the differences between the subject-matter of protection under patent and copyright law, and the nature of the permitted exceptions, the exercise of a patent covering a computer-implemented invention should not interfere with the freedoms granted under copyright law to software developers by the provisions of the Directive 91/250/EEC. Moreover, as regards developing interoperable programs, the requirement for each patent to include an enabling disclosure should facilitate the task of a person seeking to adapt a program to another; pre-existing one incorporating patented features (the requirement of disclosure has no analogue under copyright law).

Finally, it should be said that in the event that patent rights are exercised in abusive way, compulsory licenses may be available as a remedy, as well as possible recourse to competition law. Recital 18 and Article 6 make specific reference, inter alia, to the provisions on decompilation and interoperability in Directive 91/250/EEC.

In the U.S.A. the Copyright Act and the Patent Act protect software. The case law both in copyright protection and patent protection has been substantially developed. It is clear from the elaborate discussion in this chapter that both copyright and patent protections are simultaneously being used to protect software in the U.S.A.

\subsection{Patent Protection Against Curbing Piracy}

David Bainbridge opined that patents enable small and start-up companies, so important in the software industry, to get very effective protection for their 
inventions and, in the United States, many such companies have grown very quickly on the back of their patents. Although copyright provides a reasonable good degree of protection to computer programs and other software, it is not a true monopoly protection and requires proof of access and use of the protected work on the part of the infringer. ${ }^{104}$ The volume of international patent applications is rising dramatically, due in part to the increase in the U.S. patent activity resulting from the changes took place by a series of decisions of the U.S courts. ${ }^{105}$ The growth of software patenting has been described as follows:" $\left.t \mathrm{t}\right] \mathrm{he}$ volume of international patent applications has been rising by over $20 \%$ annually for the past few years, with a total of 67,007 field in 1998. According to WIPO, the rise is primarily due to increasing reliance on the Patent Cooperation Treaty (PCT), under which applicants can obtain protection in any of the 98 member States by filing a single application.",106

However acquisition of a patent takes a long time and patent litigation is very expensive. Other difficulties in case of software patents include the search for prior art which can never be exhaustive. This leaves a room of controversy that the applicant or patent office did not discover prior art. D. Bainbridge stated that a significant danger of patents is that large powerful companies can use their patents to frighten off smaller companies which do not have the resources or willingness to get involved in complex, lengthy and expensive patent litigation. He further stated that nevertheless, it seems certain that patenting of software inventions is here to stay. ${ }^{107}$

The proponents for the business method patents argue that patent protection is merited given the technological innovation reflected in such new business models and that this protection is needed in order to provide incentives for further investment in new on-line businesses. ${ }^{108}$

The effectiveness of patent protection to the software in eCommerce transaction is yet to be determined because this is a new concept in the IP law and is not widely tested. Europe is still conservatively observing the progress of software patenting in the U.S.A. and other countries like Australia, Canada, Japan etc. D. Bainbridge opines that "[h]owever the EPO, in its recent decisions, appears to be taking a more generous approach to the patentability of computer programs and it now appears that changes may be made to the EPC to facilitate the granting of patents for software inventions on a wider scale than was previously the case.",109

\footnotetext{
${ }^{104}$ See David Bainbridge, Introduction to Computer Law, P. 133, Fifth Edition, Longman, 2004.

105 The process started in State Street Bank \& Trust Co. v. Signature Financial Group, Inc. 149 F.3d 1368, 47 USPQ 2d 1596 (Fed.Cir).

${ }^{106}$ See Bruce A. McDonald, 'Intellectual Property Rights And Electronic Commerce', available at www.wrf.com/db30/cgi-bin/pubs/ip_ecommerce.pdf, last visited 24 August 2004.

${ }^{107}$ See David Bainbridge, Introduction to Computer Law, P. 133, Fifth Edition, Longman, 2004.

${ }^{108}$ See Intellectual Property On the Internet: A Survey Issues, WIPO/INT/02, December 2002, available at ecommerce.wipo.int., last visited 23 August 2004.

${ }^{109}$ See David Bainbridge, Introduction to Computer Law, PP. 133-134, Fifth Edition, Longman, 2004.
} 


\section{Regulatory Framework for Curbing Piracy}

\subsection{International Legal Framework}

Internationally, the standards for copyright protection of software are set forth in the Berne Convention for the Protection of Literary and Artistic Works and the WIPO Copyright Treaty ${ }^{110}$. Both agreements are administered by WIPO and the TRIPS Agreement, which falls under the auspices of the WTO. These international agreements provide that computer programs and information content that can be copyrighted must be protected on a nondiscriminatory basis in each country that has signed the agreement. These agreements also set minimum standards defining and safeguarding the economic interests of creators of computer programs and information content.

WIPO Primer stated that perhaps the most basic right granted under both copyright and related rights is the right of reproduction, which under the Berne Convention covers reproduction "in any manner or form." 111 This right is at the core of electronic commerce, because any transmission of a work or an object of related rights presupposes the uploading of that work or object into the memory of a computer or other digital device. In addition, when the work or object is transmitted over networks, multiple copies are made in the memory of network computers at numerous points. It is therefore necessary to determine how the reproduction right applies to such copies. In 1982, at a meeting of government experts co-organized by WIPO and UNESCO, a broad-based understanding was reached that uploading into memory should be considered as an act of reproduction. This understanding was reconfirmed in 1996 in Agreed Statements to the WCT and WPPT, which state: "The reproduction right... and the exceptions permitted thereunder, fully apply in the digital environment, in particular to the use of works in digital form. It is understood that the storage of a protected work in digital form in an electronic medium constitutes a reproduction within the meaning of the [relevant treaty right.]"112 The appropriate application of the reproduction right in the case of temporary copies in computer random access memory (RAM) continues to be a subject of debate at the national and international levels. The key question is whether such copies always require the consent of the rightsholder in order to avoid infringement. Carefully tailored

\footnotetext{
${ }^{110}$ The Treaty has been enforced from 2002.

111 Berne Convention art. 9(1). See also Rome Convention Art. 10 and TRIPS Agreement, Art. 14 (providing to phonogram producers the right to authorize or prohibit the "direct or indirect" reproduction of their phonograms). The WPPT also provides to both phonogram performers and producers a broad right of reproduction, whether "direct or indirect," and "in any manner or form." WPPT Articles. 7 and 11. For a detailed discussion of the reproduction, communication and distribution rights, see presentation of C. Clark, General Counsel, International Publishers Copyright Council, WIPO International Conference on Electronic Commerce and Intellectual Property (September 1999), at http://ecommerce.wipo.int/meetings/1999/index.html. ${ }^{112}$ See Primer on Electronic Commerce and Intellectual Property Issues,P.30, WIPO, available at
ecommerce.wipo.int/survey/, last visited 21 July 2004 .
} 
exceptions for such copies in certain circumstances have been enacted recently in the United States of America ${ }^{113}$ and proposed by the European Commission in a draft Directive. ${ }^{114}$

\subsection{European Legal Framework}

\subsubsection{E.C. Software Directive}

E.C Software Directive (the Software Directive) makes it mandatory on the Member States to protect computer programs, by copyright, as literary works within the meaning of the Berne Convention for the Protection of Literary and Artistic Works ${ }^{115}$.

The Directive expressly provided exclusive rights for the software or computer programs. Article 4 of the Directives gives an inclusive description of exclusive rights, which provides that subject to the provisions of exceptions to the restricted acts and decompilation, the exclusive rights of the right holder, shall include the right to do or to authorize:

(a) the permanent or temporary reproduction of a computer program by any means and in any form, in part or in whole. Insofar as loading, displaying, running, transmission or storage of the computer program necessitate such reproduction, such acts shall be subject to authorization by the rightholder;

(b) the translation, adaptation, arrangement and any other alteration of a computer program and the reproduction of the results thereof, without prejudice to the rights of the person who alters the program;

(c) any form of distribution to the public, including the rental, of the original computer program or of copies thereof. The first sale in the community of a copy of a program by the rightholder or with his consent shall exhaust the distribution right within the community of that copy, with the exception of the right to control further rental of the program or a copy thereof.

Member States have been directed to provide in accordance with their national legislation, appropriate remedies against a person committing any of the following acts ${ }^{116}$ :

(a) any act of putting into circulation a copy of a computer program knowing, or having reason to believe, that it is an infringing copy;

(b) the possession, for commercial purposes, of a copy of a computer program knowing, or having reason to believe, that it is an infringing copy;

\footnotetext{
113 See U.S. Digital Millennium Copyright Act of 1998 (DMCA) Title II, section 512(h); U.S. Copyright Office Summary at http://lcweb.loc.gov/copyright/legislation/ dmca/pdf, last visited 21 July 2004.

${ }^{114}$ See Art. 5(1) of Proposal for a European Parliament and Council Directive on the Harmonization of Certain Aspects of Copyright and Related Rights in the Information Society, 97/0359 (COD) (1997).
}

\footnotetext{
115 See Article 1, E.C. Software Directive.

${ }^{116}$ See Article 7, E.C. Software Directive.
} 
(c) any act of putting into circulation, or the possession for commercial purposes of any means the sole intended purpose of which is to facilitate the unauthorized removal or circumvention of any technical device which may have been applied to protect a computer program.

\subsubsection{Copyright Directive}

Article 5(1) of the Copyright Directive exempts temporary acts of reproduction "such as transient and incidental acts of reproduction" which are an "essential part of the technological process", from copyright infringement. This is aimed primarily at ISPs who merely host websites containing infringing material and/or provide the means for the passing of email correspondence, which might contain infringing material. The computer games lobby is concerned that the words "such as" do not completely restrict the scope of the exception but leave it open to argument that other forms of reproduction may lead to an exemption from liability. In addition, and more importantly, the lobby is extremely concerned that this exemption from liability for ISPs cuts across the exemptions as drafted in the E-Commerce Directive.

\subsubsection{E-Commerce Directive}

The E-Commerce Directive attempts to establish a coherent legal framework for ecommerce and to protect the public interest, i.e. the consumer, by providing a framework for dealing with the establishment of providers of on-line services, commercial communications, electronic contracts, enforcement of rights and the liability of intermediaries. Articles 12-14, deal with liability of ISPs:

Article 12 - Mere Conduit: Article 12 provides that ISP's are not liable for information transmitted on their networks provided they do not initiate the transmission, do not select the receivers of the transmission, and do not select or modify the information in the transmission. This exemption of liability extends to the automatic, intermediate and transient storage of the information provided it is not stored for any longer than reasonably necessary;

Article 13 - Caching ISPs will not be liable for the automatic, intermediate and temporary storage of information performed for the sole purpose of making the onward transmission of the information more efficient. This exemption is aimed mainly at the data protection legislation and again, there are certain conditions with which the ISP must comply; and

Article 14 - Hosting ISPs will not be liable for hosting information provided they do not have actual knowledge that the activity is illegal and, upon obtaining such knowledge, act quickly to remove it. 
All these exemptions, however, have a proviso - ISPs are liable to a prohibitory injunction i.e. although there may be no liability in damages, they will be subject to an injunction preventing the hosting, caching or conduit of infringing information.

The differences in the E-Commerce Directive and the Copyright Directive are difficult to reconcile - the E-Commerce Directive provides that an ISP is not liable (other than under a prohibitory injunction) for mere conduit, caching or hosting provided certain conditions are met. Under Article 5(1) of the Copyright Directive, however, temporary acts "such as transient and incidental acts of reproduction" are absolute exceptions to copyright infringement. Under the ECommerce Directive, therefore, a copyright infringement must take place for the conditions of exemption for ISPs to apply. Under the Copyright Directive, however, an ISP's activities do not appear to give rise to a copyright infringement in the first place. This only leaves rights holders with the availability of injunctive relief in the case of copyright infringements on the internet against ISPs, something which the computer games industry particularly considers an insufficient remedy. In addition, there is a fundamental clash of cultures between the two directives. The Copyright Directive takes ISPs out of the equation altogether whereas the E-Commerce Directive provides a framework for cooperation between rights holders and ISPs against piracy and unauthorised transmission. Under the E-Commerce Directive, ISPs' exemption from liability depends on them carrying out good practice to ensure that, amongst other things, infringing material is not disseminated on the internet. Under the Copyright Directive however, they can simply say " we're not liable, its nothing to do with us".

Now we would examine the U.K. jurisdiction in order to see how far she has incorporated the Directive in its national legislation and implemented the Directive practically as a model Country.

\subsubsection{Legal Framework of U.K.}

In the UK Copyright, Designs and Patents Act 1988 (CDPA 1988) deals with the computer program. Section 3 of this Act mentions computer program as a literary work and Section 1 of this Act describes copyright as subsisting in original literary works among other works. Therefore as per the Directive a computer program is protected by copyright as a literary work. The UK Act deviates from the Directive in its approach to the exclusive rights in a program (and equally to works stored as data in a computer) by defining "copying a work" to include storing the work in any medium by electronic means. This includes the making of copies, which are transient or are incidental to some other use of the work ${ }^{117}$. The Directive is more, specific, but more extensive also. It requires the exclusive right to cover any permanent or temporary reproduction of a program by any means or

\footnotetext{
${ }^{117}$ See Section 17 (1), (2) and (6) of CDPA 1988, available at www.hmso.gov.uk/acts/1988/ukpga_19880048 en 3.htm, last visited 22 July 2004.
} 
in any form, in part or in whole, to be authorized, including loading, displaying, running, transmission and storage ${ }^{118}$.

The CDPA 1988 in section 23 mentions the acts mentioned in Article 7 of the Software Directive as copyright infringements and provides adequate legal remedies for such infringements in sections 96-101A. In these sections various remedies like damages, injunction against service providers, order for deliver up, right to seize infringing copies and other materials have been discussed. Section 107 of the CDPA 1988 provides criminal liability for the aforementioned acts provided by Article 7 of the Copyright Directive.

Some important cases of the English Jurisdiction will be discussed here to find out the practical situation and the interpretation of the software law of U.K.

Sony Computer Entertainment v. Owen ${ }^{119}$ : In the United Kingdom, for example, Sony Computer Entertainment brought suit against various defendants, who imported "modification chips" that could be used to circumvent copy protection and region-control technologies on PlayStation 2 discs. The facts raised were substantially identical to those at issue in the earlier GameMasters decision in the United States of America.

The English court relied on a copyright-based cause of action set out in Section 296 of the Copyright, Designs and Patents Act 1988. Section 296 applies where copies of a work are issued in an electronic form that is "copy protected" and gives rights to the distributor of the copies-as if he were the copyright owner in an action for infringement-against any person who sells a device that is "specifically designed or adapted to circumvent" copy protection, knowing that the device will be used to make infringing copies. "Copy protected" is defined to include "any means intended to prevent or restrict copying of the work." The court found for Sony because the copying that was to be prevented was the unauthorized loading of the game into the computer and because the codes on the discs fell within the definition of copy protection. The defendants violated Section 296 because their chips were specifically designed to circumvent Sony's copy protection technology.

Sony Music Entertainment (UK) Ltd v Easyinternetcafe Ltd ${ }^{120}$ : Sony Music(S) sought summary judgment in its action for copyright infringement against Easyinternet (E), which owned and operated Internet cafes. In return for a fee, E recorded on to compact discs sound recordings, which had been downloaded by its customers. S alleged that the downloading of the recordings without the consent of the owners of the copyright in the recordings infringed such copyright contrary to the Copyright, Designs and Patents Act 1988 s 17(1) and s. 18(1). E argued, inter alia, that the copying of the sound recordings had been involuntary and that the defence under s. 70 of the 1988 Act was available to it. Summary: Held, granting the application, that the copyright in the sound recordings had been infringed. E's actions had not been involuntary. Furthermore, liability under s. 17 and s. 18 was strict. E could not rely on s. 70 since the

\footnotetext{
${ }^{118}$ See Cornish \& Liewelyn, Intellectual Property: Patents, Copyright, Trademarks and Allied Rights, P.766, Fifth Edition, Sweet \& Maxwell (2003).

${ }^{119}$ [2002] EWHC 45 (CH).

${ }^{120}[2003]$ EWHC 62
} 
copying had not been for "private and domestic use"; E had been conducting a business operation for profit. Although the issue did not need to be decided, the transmission of material via the Internet was a cable programme service for the purposes of s. 70, Shetland Times Ltd. V Wills 1997 S.C. 316 considered.

In Ibcos Computers v Barclays Mercantile ${ }^{121}$ it was held that the test for a claim in copyright is as follows:

(i) What are the work or works in which the plaintiff claims copyright?

(ii) Is each such work "original'?

(iii) Was there copying from that work?

(iv) If there was copying, has a substantial part of that work been reproduced?

(5) Copyright can subsist in the source code version of a computer program.

Mr. Justice Jacob determined in this case the key sections of the CDPA 1988

relating to computer program, which are as follows:

1.--(1) Copyright is a property right which subsists in accordance with this Part in the following descriptions of work--

(a) original literary, ... works, ...

(2) In this Part "copyright work" means a work of any of those descriptions in which copyright subsists.

3.--(1) In this Part--

"literary work" means any work, other than a dramatic or musical work, which is written, spoken or sung, and accordingly includes--

(a) a table or compilation, and

(b) a computer program;

...

16.--(1) The owner of the copyright in a work has, in accordance with the following provisions of this Chapter, the exclusive right to do the following acts in the United Kingdom--

(a) to copy the work (see section 17);

and those acts are referred to in this Part as the "acts restricted by the copyright."

(2) Copyright in a work is infringed by a person who without the license of the copyright owner does, or authorises another to do, any of the acts restricted by the copyright.

(3) References in this Part to the doing of an act restricted by the copyright in a work are to the doing of it--

(a) in relation to the work as a whole or any substantial part of it, and

(b) either directly or indirectly;

...

17.--(1) The copying of the work is an act restricted by the copyright in every description of copyright work; and references in this Part to copying and copies shall be construed as follows.

(2) Copying in relation to a literary, dramatic, musical or artistic work means reproducing the work in any material form.

${ }^{121}$ [1994] F.S.R. 275. 


\subsection{Legal Framework of the United States}

Federal copyright law automatically protects software from the moment of its creation. The rights granted to the owner of a copyright are clearly stated in the Copyright Act, Title 17 of the US Code. The Act gives a copyright owner "the exclusive rights" to "reproduce the copyrighted work" and "to distribute copies ... of the copyrighted work" (Section 106). It also states that "anyone who violates any of the exclusive rights of the copyright owner ... is an infringer of the copyright" (Section 501), and sets forth several penalties for such conduct. Those who purchase a license for a copy of software do not have the right to make additional copies without the permission of the copyright owner, except when it is necessary to: (i) copy the software onto a single computer in order to use the software, (ii) make a backup copy "for archival purposes only", which are specifically provided in the Copyright Act and (iii) copy the software during activation of the computer in order to repair the computer (Section 117). The license accompanying the product may allow additional copies to be made -- be sure to review the license carefully. The unauthorized duplication of software constitutes copyright infringement, regardless of whether it is done for sale, for free distribution, or for the copier's own use. Moreover, those who copy are liable for the resulting copyright infringement whether or not they knew their conduct violated federal law. Penalties include liability for damages suffered by the copyright owner plus any profits of the infringer that are attributable to the copying, or statutory damages of up to $\$ 150,000$ for each work infringed. The unauthorized duplication of software is also a Federal crime if done "willfully and for purposes of commercial advantage or private financial gain (Title 18 Section 2319(b))." Criminal penalties include fines of as much as $\$ 250,000$ and jail terms of up to 5 years.

Congress's authority to legislate concerning copyright issues derives directly from the U.S. Constitution. Article 1, Section 8, Clause 8 of the Constitution grants to Congress the power to "promote the Progress of Science and the Useful Arts, by securing for limited times to authors and inventors the Right to their respective Writings and Discoveries." 122 Congress codified modern copyright law with the U.S. Copyright Act of $1976^{123}$. As written in the landmark 1991 Feist Publications case ${ }^{124}$, the purpose for copyright protection is "to assure authors the right in the their original expression, (and) to encourage others to build freely upon the ideas and information conveyed by a work."125

Under the law, copyright protects "original works of authorship fixed in any tangible medium of expression", and grants to the copyright holder a set of exclusive rights that last for the life of the author plus fifty years ${ }^{126}$. These rights include the right to reproduce, distribute, perform, display or license their work $^{127}$. Copyright infringement occurs when someone other than the holder of

\footnotetext{
${ }^{122}$ U.S. Const., art I, Sec. 8, cl. 8.

123 17 U.S.C. Sec. 106.

${ }^{124}$ Feist Publications, Inc. v. Rural Tel. Service, 499 U.S. 340 (1991).

${ }^{125}$ Id.at 350.

${ }^{126}$ See, 17 U.S.C. Section 501 (a).

${ }^{127}$ See, 17 U.S.C. Section 106.
} 
the copyright engages in one or more of the exclusive activities without the consent of the copyright holder ${ }^{128}$. The major limitation on a copyright holder's exclusive right to control a copyrighted work is the doctrine of fair use, addressed later in this paper.

There are two forms of copyright infringement: direct copyright infringement and secondary copyright infringement. Secondary copyright infringement is again subdivided into two categories: contributory and vicarious copyright infringement.

To sustain a case of direct copyright infringement, a plaintiff must initially show proof of ownership of a valid copyright and copying by the defendant ${ }^{129}$. The copying requirement is satisfied by either direct evidence of copying or by showing that the defendant had access to the copyrighted work and that the works in question are substantially similar to the originally copyrighted work ${ }^{130}$. Once these initial requirements are satisfied, the plaintiff must prove that the defendant used the copyrighted work in a way that violated one of the copyright holder's exclusive rights described in Section 106 of the U.S. Code. A finding of direct copyright infringement does not require proof of knowledge or intent to infringe, but only proof that the defendant's activities violated one of the copyright holder's exclusive rights ${ }^{131}$. Secondary copyright infringement is applied in instances in which the defendant did not personally engage in the violating activity but still bears some responsibility for the infringement ${ }^{132}$. There are two categories of secondary copyright infringement: contributory and vicarious copyright infringement ${ }^{133}$. A defendant is liable for contributory copyright infringement if "with knowledge of the infringing activity, induces, causes or materially contributes to the infringing conduct of another."134 A defendant is liable for vicarious copyright infringement where the defendant has the right and ability to control or police the infringer's acts and receives a direct financial benefit from the infringement ${ }^{135}$.

There is no mention of secondary copyright infringement in the 1976 Copyright Act. Concerning the legal authority underpinning the concept of secondary copyright infringement, the Supreme Court, in Sony Corp. v. Universal City Studios_, ${ }^{136}$ wrote the following: "the absence of express language in the copyright statute does not preclude the imposition of liability for copyright infringement on certain parties who have not themselves engaged in the infringing activities. Vicarious liability is imposed in virtually all areas of the law, and the concept of contributory infringement is merely a species of the broader problem of identifying the circumstances in which it is just to hold an individual liable for the actions of another." 137

${ }^{128} \mathrm{Id}$.

${ }^{129}$ Howard v. Sterchi , 974 F.2d 1272, 1275 (11th Cir 1992)

${ }^{130} \mathrm{Id}$.

13117 U.S.C. Section 501 (a).

${ }^{132}$ Shapiro, Bernstein \& Co. V. H.L. Green Co., 316 F.2d 304, 308 (2d Cir. 1963).

${ }^{133}$ Gershwin Publishing Corp. v. Columbia Artists , 443 F2d 1159, 1162 (2d Cir 1971).

${ }^{134} \mathrm{Id}$.

${ }^{135}$ Id. at 1163 .

${ }^{136}$ Sony Corp. v. Universal City Studios, 464 U.S. 417 (1984).

${ }^{137}$ Id.at 435 . 
The doctrine of fair use is the most common affirmative defense to a finding of copyright infringement ${ }^{138}$. This limited doctrine allows individuals to use copyrighted works for certain specific purposes without the consent of the copyright holder ${ }^{139}$. Within the limits of fair use case law, the fair use doctrine states that the use of a copyrighted work in scholarly papers, in news reports, in education, and in other similar situations does not constitute copyright infringement ${ }^{140}$. Section 107 of the U.S. Code lists four factors used in determining fair use. The four factors are: 1) the purpose and character of the use, including whether the use is commercial in nature, 2) the nature of the copyrighted work, 3) the amount and substantiality of the portion used in relation to the copyrighted work as a whole, and 4) the effect of the use upon the potential market for or value of the copyrighted work ${ }^{141}$.

While the fair use doctrine is often invoked in cases involving alleged on-line copyright infringement, there has yet to be a case in which the defense has been used successfully ${ }^{142}$. It would be useful to discuss some important cases of U.S. Jurisdiction in order to realize the implementation of the aforementioned law in practice and judicial trend of considering the problem of curbing software piracy in eCommerce.

In Playboy Enterprises Inc. v. Frena ${ }^{143}$, the defendant was an operator of a computer bulletin board service (BBS) that, unknown to the defendant, distributed unauthorized copies of Playboy Enterprises, Inc.'s (PEI) copyrighted photographs.

For a fee, anyone with an appropriately equipped computer could log onto the BBS, browse through different BBS directories to look at the pictures, download the high quality computerized copies of the photographs, and then store the images onto their home computer ${ }^{144}$. Among the many pictures stored on Frena's BBS were one hundred and seventy that were copies of Playboy's copyrighted photographs. Frena admitted that the materials were displayed on the BBS and that he never received consent from Playboy. However, Frena argued that he did not personally upload any of the infringing pictures onto the BBS (his subscribers had uploaded the images) and that he removed the infringing pictures as soon he was made aware of the matter.

On these facts, the court found Frena guilty of copyright infringement. In making its determination, the court analyzed the elements needed for copyright infringement as follows. In order to establish a prima facie case of copyright infringement, the plaintiff must show ownership of the copyright and "copying" by the defendant. In this case there was no question that Playboy owned the copyrights on the photographs due to the fact that at trial, Frena had offered no

\footnotetext{
${ }^{138}$ See Intellectual Propoerty \& the NII, at 128

${ }^{139}$ See Supra note 115.

${ }^{140}$ Supra note 115 at 73.

${ }^{141} 17$ U.S.C. Sec. 107

${ }^{142}$ Mari-Frances Kline , Copyright Infringement and Liability on the Information Superhighway, Stetson University Law School, (April 1997)

${ }^{143}$ Playboy Enterprises, Inc. v. Frena, 839 F. Supp. 1552 (M.D. Fla, 1993).

${ }^{144}$ Ibid, at 1554.
} 
evidence to rebuff Playboy's copyright documentation. As for copying, the court noted that since evidence of copying is rarely found, copying could be inferentially proven by showing that defendant Frena had access to the copyrighted work, the work is substantially similar to the copyrighted work, and that one of the rights statutorily guaranteed to copyright owners is implicated by the defendant's actions. In this case there was no question about the elements of access and similarity-Playboy sells 3.4 million copies of its magazine per month in the United States, and the pictures were essentially exact copies of the copyrighted photographs. The only remaining issue was whether the defendant's actions implicated one of the copyright holders exclusive rights.

The court held that Frena's actions had infringed Playboy's exclusive right to distribute the works and the exclusive right to display the works. Concerning the right to distribute, the court held that there was no question that Frena supplied a product containing unauthorized copies of a copyrighted work. As for display rights, the court held that Frena's display of the copyrighted materials to his subscribers constituted a public display even though his subscribers were limited in number.

Frena defended his use as within the scope of the fair use exception to copyright infringement. His argument, however, fell on deaf ears. The court found that Frena's actions were commercial in nature and of the sort that if they were to become widespread would result in a substantially adverse impact on the potential market for or value of the plaintiff's work and therefore were not within the fair use exception.

Concerning Frena's argument that he had not uploaded any of the infringing photographs and was not aware that the photographs were in fact infringing PEI's copyrights, the court wrote that

"it does not matter that Defendant Frena may have been unaware of the copyright infringement. Intent to infringe is not needed to find copyright infringement. Intent or knowledge is not an element of copyright infringement, and thus even an innocent is liable for infringement; rather, innocence is significant to a trial court when it fixes statutory damages"

Because knowledge is not an element of direct copyright infringement, the court set forth a standard that the creation and/or operation of a BBS can be sufficient to establish direct infringement liability where copyrighted materials appears on the system.

But the principles settled in Plaboy's Case were reversed in Religious Technology Center v. Netcom On-Line ${ }^{145}$ case. In this case Copyright holders brought infringement action against operator of computer bulletin board service (BBS) and Internet access provider, seeking to hold defendants liable for copyright infringement committed by BBS subscriber. Access provider filed motion for summary judgment, operator filed motion for judgment on the pleadings, and holders filed motion for preliminary injunction. The District Court, Whyte, J., held that: (1) access provider was not directly liable for copies that were made and stored on its computer; (2) fact issue as to whether access provider had knowledge of infringing activity precluded summary judgment on contributory infringement claim; (3) access provider did not receive direct financial benefit from infringing activity necessary to hold it vicariously liable; (4) fact issues precluded summary judgment on access provider's fair use defense; (5) bulletin

${ }^{145} 907$ F. Supp. 1361. 
board operator could not be held liable on theories of direct infringement or vicarious liability; (6) holders' allegations were sufficient to raise issue of contributory infringement on part of operator; and (7) holders were not entitled to preliminary

Motions denied.

injunction.

The following important principles were established in this case:

(a) Storage on defendant's system of infringing copies and retransmission to other servers is not direct infringement by computer bulletin board service (BBS) operator of exclusive right to reproduce work where such copies are uploaded by infringing user. 17 U.S.C.A. § § $101 \& 501$.

(b) Internet access provider was not directly liable for unauthorized copies of copyrighted work that were made and stored on its computer while transmitting computer bulletin board service's (BBS) Usenet postings to and from the Internet; access provider did not take any affirmative action that directly resulted in copying other than installing and maintaining system whereby software automatically forwarded messages received from subscribers onto Usenet and temporarily stored copies on its system, and its actions were necessary to having working system for transmitting Usenet postings to and from the Internet. 17 U.S.C.A. § 101.

(c) Liability for participation in copyright infringement will be established where defendant, with knowledge of infringing activity, induces, causes or materially contributes to infringing conduct of another. 17 U.S.C.A. § 501.

(d) Where computer bulletin board service (BBS) operator cannot reasonably verify claim of copyright infringement, either because of possible fair use defence, lack of copyright notice on copies, or copyright holder's failure to provide necessary documentation to show that there is likely infringement, operator's lack of knowledge will be found reasonable and there will be no liability for contributory infringement for allowing continued distribution of works on its system. 17 U.S.C.A.§501.

(e) Operator of computer bulletin board system (BBS) could not be held liable for direct copyright infringement when subscriber posted infringing works on system without authorization, absent allegations that operator took any affirmative steps to cause copies to be made. 17 U.S.C.A. § 501.

(f) Operator of computer bulletin board system (BBS) could not be held vicariously liable for subscriber's copyright infringement, absent claim that operator financially benefitted from infringing postings. Operator of computer bulletin board system (BBS) could not be held vicariously liable for subscriber's copyright infringement, absent claim that operator financially benefitted from infringing postings. Operator of computer bulletin board system (BBS) could not be held vicariously liable for subscriber's copyright infringement, absent claim that operator financially benefitted from infringing postings. 17 U.S.C.A. § 501.

In this case a different view was taken in respect of Playboy's holding that the defendant who is an operator of a BBS infringed plaintiff's exclusive right to distribute the work and exclusive right to display the work. It was held in Religious Technology Center case the court was not entirely convinced that the mere possession of a digital copy on a BBS that is accessible to some members of the public constitutes direct infringement by the BBS operator. Such a holding suffers from the same problem of causation as the reproduction argument. Only the subscriber should be liable for causing the distribution of plaintiffs' work, as the contributing actions of the BBS provider are automatic and indiscriminate. Erlich could have posted his messages through countless access providers and the outcome would be the same: anyone with access to Usenet newsgroups would be able to read his messages. There is no logical reason to draw a line around Netcom and Klemesrud and say that they are uniquely responsible for distributing Erlich's messages. Netcom is not even the first link in the chain of distribution--Erlich had no direct relationship with Netcom but dealt solely with Klemesrud's BBS, which used Netcom to gain its Internet access. Every Usenet server has a role 
in the distribution, so plaintiffs' argument would create unreasonable liability. Where the BBS merely stores and passes along all messages sent by its subscribers and others, the BBS should not be seen as causing these works to be publicly distributed or displayed. In Costar Group v. Loopnet ${ }^{146}$ Case Circuit Court supported the view taken in Religious Technology Center's Case. In Costar Group's case Real estate listing service brought action against operator of web site, which was hosting online real estate listings for brokers, alleging copyright infringement and related torts. The United States District Court for the District of Maryland, Deborah K. Chasanow, J., granted summary judgment for operator, and service appealed.

Holdings: The Court of Appeals, Niemeyer, Circuit Judge, held that:

(1) operator's conduct did not constitute direct infringement, and

(2) safe harbor provision in Digital Millennium Copyright Act (DMCA) was not exclusive.

The decision of the Trial Court was Affirmed.

Gregory, Circuit Judge, dissented and filed opinion.

The following important principles were settled in this case:

(a) Elements of copyright infringement claim are: (1) ownership of valid copyright, and (2) copying of constituent elements of work that are original. 17 U.S.C.A. § 501.

(b) While Copyright Act does not require that direct infringer know that he is infringing or that his conduct amount to willful violation of copyright owner's rights, it nonetheless requires volitional conduct by person who causes infringement in some meaningful way. 17 U.S.C.A. § 501.

(c) Internet service provider (ISP) could not be held liable as direct copyright infringer when its facility was used by subscriber to violate copyright without intervening conduct of ISP; ISP, which provided system that automatically received subscriber's infringing material and transmitted it to Internet at instigation of subscriber, had not itself fixed copy in its system of more than transitory duration. 17 U.S.C.A. $\S \S 106,501$.

(d) Safe harbor provision in Digital Millennium Copyright Act (DMCA) for internet service providers (ISPs) is not exclusive, and does not preclude ISPs from asserting other affirmative defenses or from arguing that its conduct does not constitute prima facie case of infringement. 17 U.S.C.A. $\S 512(1)$.

(e) Internet service providers (ISPs), when passively storing material at direction of users in order to make that material available to other users upon their request, do not "copy" material in direct violation of Copyright Act. 17 U.S.C.A. § 106.

(f) Automatic copying, storage, and transmission of copyrighted materials, when instigated by others, does not render Internet service provider (ISP) directly liable for copyright infringement; ISP can become liable indirectly upon showing of additional involvement sufficient to establish contributory or vicarious infringement, but even then may still look to Digital Millennium Copyright Act (DMCA) for safe harbor if it fulfilled conditions therein. 17 U.S.C.A. §§§ 106,501,512.

(g) Operator of web site that hosted online real estate listings for brokers did not lose its status as passive Internet service provider (ISP) which was immune from liability for direct copyright infringement merely because it screened brokers' photographs for propriety before allowing them to be posted; cursory screening process did not add volition to operator's involvement in storing copy of photograph. 17 U.S.C.A. §§ 106,501. 
It is noteworthy to mention here the minority view taken by the Circuit Judge Gregory. The Minority Judge basically opposed the majorities view that cursory screening process did not add volition ${ }^{147}$ to operator's involvement in storing copy of photograph. The minority Judge opined that when a subscriber wishes to post a photograph on the site, such posting is not automatic or immediate. Instead, the photograph is transferred to LoopNet's computers where one of the company's employees can review the photo to ensure (1) it is an image of commercial real estate, and (2) it is not an obviously copyrighted image. At this stage of the process the LoopNet employee has a choice, he or she can reject the photograph because it does not comply with the above-noted criteria, or he or she can "accept" the photograph, at which time it becomes accessible on the subscriber's web page to which the text was previously and automatically uploaded. He further opined that that the majority expands the non-volitional defense well beyond Netcom and subsequent holdings, and gives direct infringers in the commercial cybersphere far greater protections than they would be accorded in print and other more traditional media.

The minority Judge further criticised the Majority's view when he opined that the majority also attempts to argue that LoopNet has not made a "copy" of the image. In doing so, it largely accepts LoopNet's argument that rather than copying the images, the company simply "moves" an image already stored by modifying the computer's directory, thus transforming the image from one not accessible by users who "hit" the website to one that users can view. The majority states "downloading is a temporary, automatic response to the user's request, and the entire system functions solely to transmit the user's data to the Internet." Ante at 551; see also id. at 551. The majority's analysis, however, rests on a technicality that does not comport with reality. While LoopNet may not "copy" the images in a traditional sense, the fact is that without LoopNet's volitional action, the subscriber's image would never be uploaded to the subscriber's webspace on the LoopNet site no matter how much that subscriber might desire to have the image so appear. See MAI Sys., Corp.v. Peak Computer, Inc., 991 F.2d511(9 $9^{\text {th }}$ Cir.1993) (holding loading of data to RAM "creates a 'copy' under the Copyright Act"). Thus, LoopNet is in every sense a publisher controlling content. In short, it is LoopNet, not the subscriber, who has the final say in selecting and determining photographic content on the website.

The Minority Judge's view in this case summons reasonable appreciations and gives us a different perspective of the problem. If we accept the majority view then it would be very difficult to make liable ISPs or operators of BBS who are a very important factor in the infringements of software on the Internet.

\subsection{Difference Between UK and US Law}

(a) Difference Between Copyright laws

\footnotetext{
147 "volition" is defined as "the act of willing or choosing[; ] the act of deciding (as on a course of action or an end to be striven for) [; ] the exercise of the will ... [or] the termination of an act or exercise of choosing or willing[; ] a state of decision or choice." Webster's Third New International Dictionary of the English Language, unabridged 2562 (1981). See minority decision in Costar Group v. Loopnet.
} 
In Ibcos Computers v Barclays Mercantile case Jacob J held that the general structure of a computer program was a copyright work as an original compilation. He rejected the decision of Total Information Processing System v Daman, that because a program has a particular function and that function can only be achieved in one or a limited number of ways, it cannot be a copyright work. As he explained, the fact that a work is functional does not prevent it from being a copyright work if it involves sufficient skill, labour and judgment on the part of the author. He also opined that it is incorrect to state that as a general rule that ideas can never be copyright works. He has distinguished between the general ideas and the ideas which involve sufficient skill, labour and judgment to be copyrighted works. Jacob J found a difference between UK copyright law and US copyright law in this important respect. The US statute and case law quite clearly exclude protection for functional works and ideas of software. As a result, the tests developed by the US courts to exclude protection for ideas and functional aspects of computer programs are not relevant when considering the subsistence of copyright in computer programs in the United Kingdom. In the John Richardson case, Ferris J had also found that there were some differences between the tests for the subsistence of copyright in US and UK law but apparently he has taken the view that in practice these differences would not affect the outcome of a case involving computer programs. By contrast In Ibcos Computers v Barclays Mercantile, Jacob J was of the opinion that the difference between the approaches of the UK and US courts were substantial and could lead to different results ${ }^{148}$.

\section{(b) Difference Between ISP's Liability}

In the UK the CDPA does not provide any express limitations on service provider's liability for copyright infringements. We have already seen that EC Copyright Directive neither provides any limitations on liability of ISPs nor does it provides any specific liability of ISPs for copyright infringements. On the other hand EC E Commerce Directive provides specific limitations on the liability of ISPs for copyright infringement and it also provides provision for prohibitory injunction against ISPs for preventing the hosting, caching or conduit of infringing information ${ }^{149}$. In the UK, ISPs are generally not liable for the infringing use of the facilities provided by them. Commercial libraries renting out sound recordings and manufacturers of double-headed audio tape decks have been held not liable despite the fact that their services and products rendered infringement easy and probable ${ }^{150}$. Hector L Macqueen ${ }^{151}$ stated two crucial

\footnotetext{
${ }^{148}$ See Laurence Jacobs, "Demystifying Copyright Infringement of Computer Software [1994] 5 EIPR 206" Readings In Intellectual Property, PP. 103-104, Edited by Alison Firth et al. Sweet \& Maxwell (1998)

${ }^{149}$ See sub section 4.2.3. At PP. 53-54.

${ }^{150}$ CBS Inc v Ames Records and Tapes Ltd [1982] Ch 91; CBS Songs Ltd v Amstrad Consumer Electronics ple [1988] AC 1013.

${ }^{151}$ See HL Macqueen, "Copyright and the Internet", Law \& the Internet.Com/ a Framework for electronic Commerce,P. 200, Edited by Lilian Edwards \& Charlotte Waelde, Hart Publishing (2000).
} 
factors in these cases namely : whether lawful activity was possible with the facilities provided, and whether the defendants had given express warnings to customers against use for infringing copying.

In the US before the enactment of the Digital Millennium Copyright Act 1998 it was held in Religious Technology Center v Netcom Online Communication Service $^{152}$ that a service provider could be liable as a contributory infringer if it knew or ought to have known that infringement was taking place on its system, and if simple steps to prevent this were not taken. But the Court provided some relief to the providers and operators in holding that the claim of primary infringement had to be reasonably verifiable by them before they could be held to have failed to act. In Sega Enterprises Ltd v Maphia ${ }^{153}$ specific findings of contributory infringements were made by the District Court against bulletin board operators on the basis of knowledge of and participation in the primary infringing activities (copying video games) by provisions of facilities, solicitation of unauthorised uploading by subscribers, the provisions of 'road maps' on the bulletin board to identify games available for downloading, and the sale of copies to facilitate the playing of the downloaded games. The Digital Millennium Copyright Act 1998 exempts the service provider from liability where it has no knowledge or information about the infringing material in its system, acts expeditiously to remove or block access to material when knowledge or information comes to hand, does not receive any financial benefit directly attributable to the infringing material, and complies with certain 'notice and take down' provisions of the Act enabling copyright owners to require the service provider to remove or block access to infringing material ${ }^{154}$.

\subsection{International Standard Setting}

We have discussed some basic differences prevailing between the U.S. laws and E.C. laws (Which includes the law of the U.K.) in respect of software protection through copyright law. But we have already mentioned in the first chapter that jurisdiction, choice of law and enforcement issues in the environment of eCommerce are complicated and difficult. To address these issues we must have a unified standard through out the world particularly in respect of determining: exclusive rights of the authors of software, liability of the Internet Service Providers ( ISPs) and ambit of fair use.

\footnotetext{
${ }^{152}$ See for details P.60.

153857 F.Supp 679, 1994.

15417 USC, Title II. See HL Macqueen, “Copyright and the Internet”, Law \& the Internet.Com/ a Framework for electronic Commerce P. 201, Edited by Lilian Edwards \& Charlotte Waelde, Hart Publishing (2000).
} 


\section{Technological Protection Measures}

Suffering huge financial losses as well as the loss of the goodwill of business, entrepreneurs have made tremendous efforts and invested a lot of money to create and deploy technological measures to protect their copyrighted articles from pirates, and in many cases, to protect the public from dangerous copies. Technological enforcement is a preventive measure against copyright infringements. Technological devices with adequate legal support would be a most effective measure for curbing software piracy in eCommerce.

The WIPO Internet Treaties, the WCT and WPPT, bind the Contracting Parties to provide legal protection and effective remedies against the circumvention of effective technological measures that are used by the right holder. This area is fast changing because, as the saying goes, "What one man can create, another can copy." This applies not only to the products themselves, but also to the technological means of protection. Conceptually, technological measures must be designed to shift the balance of risk to the counterfeiter; the probabilities are thus higher that he or she will get caught, pay a large fine, and perhaps go to prison. This concept permeates the design and deployment of technological measures. In order for technological measures to be successful in their assigned roles, they must be sensitive to cost, which is ultimately passed on to the consumer. If the price of the technology protecting the software product doubles its cost, it will be un useable; likewise, if the technological measures disrupt normal distribution of the product or are unfriendly to the consumer, for example, impeding or even preventing use of the product. Because of these various and necessary considerations, business has understood that only through a combination of different technological measures, can software products be protected, and counterfeiters be defeated ${ }^{155}$.

There are basically four different types of technological measures by which entrepreneurs attempt to protect their software products and enforce their intellectual property and other rights: optical technology, biotechnology, chemical technology, and electronic technology. A brief description of the optical and electronic measures is given below. Optical technological measures, which are visual in nature and make use of light in various ways, have become quite popular with manufacturers. The most prevalent of those technologies is the hologram, a two or three-dimensional device which reflects an image, or images, and which is sometimes accompanied by movement reflected in the image(s). The main reason holograms have become the most used optical technology is that they are the most difficult, costly, and technically challenging to copy.

Electronic measures include the following: (1) The magnetic strip - like the ones protecting credit and bank cards, they store large amounts of information in coded form, which can be read with an appropriate scanner. (2) The smart card - a plastic card which incorporates a computer chip which stores and, upon proper

\footnotetext{
${ }^{155}$ See A Power Tool for Economic Growth, P.325, WIPO Publication, www.wipo.int/about_wipo/en/dgo/wipo_pub_888/index_wipo_pub_888.html, last visited 20 May 2004.
} 
access, gives large amounts of information. This is expensive but effective and will surely be one avenue for future enforcement. (3) Electronic encryption, which scrambles the electronic signal, making it unreadable by normal means such as computers, CD players, VCRs, and DVD players. The makers of the goods and legitimate purchasers are the only ones who legitimately have possession of the key necessary to unlock the encryption ${ }^{156}$.

\subsection{Technological enforcement in Australia}

The House of Representatives Standing Committee on Legal and Constitutional Affairs of Australian Parliament opined in its Report 'Cracking Down on Copycats' that one way to protect copyright material from infringement is to use a technological protection device. Such devices operate by either aiding the identification of copyright material, or by restricting access to, or the use of, copyright material. Protection devices have the advantage of providing intrinsic protection to copyright material; they prevent infringement from occurring, rather than merely providing a remedy once it has occurred.

It further opined that technological protection devices are especially important in the electronic environment. This is because the possibilities for infringement in the electronic environment are vast, rendering legal protection largely ineffectual. The Copyright Amendment (Digital Agenda) Act 2000 of Australia refers to two types of protection devices that can apply to material in electronic form: The CADA introduces new remedies and offences in relation to the manufacture, sale and other dealings with broadcast decoding devices that facilitate unauthorised access to encoded broadcasts. The provisions do not prevent the personal use of such devices, but a civil remedy is provided for the use of a decoding device for a commercial purpose (for example the unauthorised reception of an encoded sporting event in a hotel or pub). A broadcast decoding device is defined to mean a device that is designed or adapted to enable a person to gain access to an encoded broadcast without the authorisation of the broadcaster, by circumventing, or facilitating the circumvention of, the technical means or arrangements that protect access in an intelligible form to the broadcast.

OVID Australia Pty Ltd (Ovid) described a new technological protection device that has been developed in Australia. The device protects physically embodied copyright material, such as compact discs (CDs), digital video discs (DVDs), floppy discs and videos. It takes the form of a foil or veneer which can be applied to the physical body (the disc or video), and which has special optical properties - a so-called optical variable device. The foil identifies legitimate material, and enables it to be distinguished from counterfeit copies ${ }^{157}$.

\footnotetext{
${ }^{156}$ See A Power Tool for Economic Growth, P.326, WIPO Publication, www.wipo.int/about_wipo/en/dgo/wipo_pub_888/index_wipo_pub_888.html, last visited 20 May 2004.

157 See The Parliament of the Commonwealth of Australia, House of Representatives, Standing Committee on Legal and Constitutional Affairs: Cracking Down on Copycats: Enforcement of Copyright in Australia, P.35, November 2000.
} 


\subsection{The Present Legal Framework for Technological Enforcement}

\subsubsection{WIPO Copyright Treaty}

Article 11 of the WCT, entitled "Obligations Concerning Technological Measures," provides:

"Contracting Parties shall provide adequate legal protection and effective legal remedies against the circumvention of effective technological measures that are used by authors in connection with the exercise of their rights under this Treaty or the Berne Convention and that restrict acts, in respect of their works, which are not authorized by the authors concerned or permitted by law."158

The provision of article 11 is well explained by the WIPO Standing Committee's Report on Copyright. It opined that prohibiting technologies alone might be permissible because that would be one (or an additional) way in which such actual acts of circumvention could effectively be prevented. The effective technological measures do not mean that the measures should be completely effective. If a measure itself is completely effective then no law is require to protect it. It is also stated in the Report that the provision would not require a contracting party to prohibit circumvention in connection with fair use. It further opined that effective technological measures cover both copyright control and access control. The Standing Committee in its Report categorically mentioned that in any event, as suggested above, Article 11 does not prohibit Contracting Parties from affording protections for technological measures that exceed the requirements of the WIPO

Treaties. Furthermore, the WIPO Treaties permit Contracting Parties to use existing legal remedies against the circumvention of technological measures, including Digital Rights Managements(DRMs). In this regard, Article 11 of the WCT and Article 18 of the WPPT do not require specific new anti-circumvention legislation and, indeed, some states have since determined that their existing legal regimes are adequate and effective to meet their obligations under the WIPO Treaties.

The WCT also establishes benchmarks for protection of rights management information. Rights management information is defined as information that identifies the work, the author of or the owner of any rights in the work, or information about the terms and conditions of use of the work, as well as any numbers or codes that represent such information.

Article 12 of the WCT and Article 19 of the WPPT require that the Contracting Parties provide "adequate and effective legal remedies" against two types of acts. Persons who knowingly perform acts that they know will induce, enable, facilitate or conceal an infringement (or have reason to know that their acts will do so) may not:

${ }^{158}$ WIPO Copyright Treaty, Article 11 (Adopted December 20 1996). 
- Remove or alter any electronic rights management information without authority; or

- Distribute, import for distribution, broadcast or communicate to the public without authority works or copies of works knowing that the electronic rights management information has been removed or altered without authority ${ }^{159}$.

The Standing Committee Report Stated that:

The WCT also established certain rights under copyright, including authors' right of distribution and right of communication to the public, "including the making available to the public of their works in such a way that members of the public may access these works from a place and at a time individually chosen by them." ${ }^{\text {"60 }}$ Rights holders have thought that having these rights would be critical to best make use of the opportunities in the digital environment. These rights were especially important for the distribution of content over the Internet and through other digital media, including television, broadcasting and cable. To address concerns of certain nations and user communities, however, Article 10 states expressly that the Contracting Parties may provide for "limitations of or exceptions to the rights granted to authors," so long as such exceptions are confined to "special cases that do not conflict with a normal exploitation of the work and do not unreasonably prejudice the legitimate interests of the author."161

\subsubsection{United States of America}

United States of America implemented the anti-circumvention provisions of the WIPO Treaties in Title I of the Digital Millennium Copyright Act ("DMCA"), ${ }^{162}$ in October 1998.

At a high level, the anti-circumvention provisions of the DMCA, which implement Article 11 of the WCT and Article 18 of the WPPT, reflect a matrix of prohibitions:

\begin{tabular}{|l|l|l|}
\hline & Act of Circumvention & Circumvention Tools \\
\hline $\begin{array}{l}\text { Access Control } \\
\text { Technological } \\
\text { Measure }\end{array}$ & $\begin{array}{l}\text { Prohibited (\$ 1201 } \\
\text { (a)(1)) }\end{array}$ & $\begin{array}{l}\text { Prohibited (§ } \\
\text { 1201(a)(2)) }\end{array}$ \\
\hline $\begin{array}{l}\text { Copyright Control } \\
\text { Technological } \\
\text { Measure }\end{array}$ & $\begin{array}{l}\text { Not prohibited (by } \\
\text { DMCA) }\end{array}$ & Prohibited (§ 1201(b)) \\
\hline
\end{tabular}

159 See WIPO Standing Committee on Copyright and Related Rights, "Current Developments in the Field of Digital Rights Management", Tenth Session, November 3-5, 2003, www.wipo.int/documents/en/meetings/2003/sccr/pdf/sccr_10_2.pdf, last visited 26 May 2004.

${ }^{160}$ WCT, Art. 6 (right of distribution) and Art. 8 (right of communication to the public).

${ }^{161}$ WCT Art. 10.

162 See WIPO Copyright and Performances and Phonograms Treaties Implementation Act of 1998 ,

Title I of the Digital Millennium Copyright Act (codified at 17 U.S.C. Chapter 12). 
As noted, the WIPO Treaties arguably only require adequate and effective protection against circumventing acts and only with respect to measures used to protect authors' exercise of their copyright rights under the Berne Convention, the WCT and the WPPT. The DMCA, however, exceeds the minima of the WIPO Treaties to separately prohibit both circumventing acts and circumventing products, and with respect to both "access control" and "copyright control" technological measures used to protect a copyrighted work ${ }^{163}$.

\subsubsection{Limitations and Exceptions of DMCA}

There are various limitations and exceptions provided in DMCA. Some of the most significant limitations and exceptions are discussed below.

Relationship to Copyright Infringement, Including Fair Use: The DMCA states that Section 1201 does not affect "rights, remedies, limitations, or defenses to copyright infringement, including fair use." ${ }^{\prime 64}$ The provision superficially might be read as protecting fair use activities. Nevertheless, as courts interpreting the provision have found, it is clear that any rights and defenses under copyright law are separate from and not affected by the new rights, remedies and exceptions of the anti-circumvention provisions: it is no defense to a DMCA claim brought under Section 1201(a)(1) to argue that circumvention was done for the purpose of carrying out an entirely lawful, fair use activity ${ }^{165}$.

Relationship to Vicarious or Contributory Copyright Infringement: The DMCA provides that nothing in Section 1201 will "enlarge or diminish vicarious or contributory" copyright liability for any technology. That language is largely meaningless, however, because, as noted above, if a product violates Section 1201(a)(2) or Section 1201(b) that violation may be prosecuted-under the standards of Section 1201-without regard to whether the product assists in or contributes to the infringement of copyright. No Mandate Provision for Ordinary Products: In response to concerns from manufacturers of computer, consumer electronics and telecommunications products that their products might be held to violate Section 1201, the DMCA provides that the provision does not require that their legitimate products be designed, or that parts and components need to be designed or selected, to "provide for a response to any particular technological measure." This clause has generally been referred to as the "no mandate" provision, because it means that such products will not be required to affirmatively respond to a technological measure in order to avoid an allegation that they circumvent; in other words, only affirmative acts of circumvention (rather than the mere non-response to a technology) will violate Section 1201. Manufacturers may avail themselves of this provision, however, only "so long as" the product, part or component "does not otherwise fall within the prohibitions" of the section. Although the meaning of this proviso is not altogether clear, some

\footnotetext{
${ }^{163}$ See WIPO Standing Committee on Copyright and Related Rights, "Current Developments in the Field of Digital Rights Management", Tenth Session, November 3-5, 2003, www.wipo.int/documents/en/meetings/2003/sccr/pdf/sccr_10_2.pdf, last visited 26 May 2004.

${ }^{164} \S \mathbf{1 2 0 1 ( c ) ( 1 ) .}$

${ }^{165}$ Universal City Studios, Inc. v. Corley, 273 F.3d 429.
} 
of the legislative history is to the effect that a product must be looked at in its entirety to determine why it failed to respond, whether for some legitimate design reason or for some illicit purpose of circumvention. The language itself suggests that a manufacturer cannot rely on this provision where some functionality of the product does affirmatively engage in bypassing, avoiding or otherwise circumventing a technological measure. In addition to these limitations, Section 1201 contains other specific seven exceptions, which are as follows:

i. Nonprofit Libraries, Archives and Educational Institutions;

ii. Law Enforcement, Intelligence and Other Government Agencies;

iii. Reverse Engineering of Computer Programs;

iv. Encryption Research;

v. Protection of Minors;

vi. Protection of Personally Identifying Information; and

vii. Security Testing.

The WIPO Treaties do not prohibit Contracting Parties from creating exceptions to the general proscription on circumvention. The requirement that the legal remedies must be "adequate" and "effective" does imply, however, that an implementing country may decide to weigh the benefits and burdens, to rights holders and users, of prohibiting circumvention. This is just what happened in Congress, which adopted seven exceptions that are, however, widely conceded to be both very narrow and highly particularized. In most situations, the exceptions would, on their own terms, be inapplicable. All of these exceptions are applicable to the act of circumvention of access controls, but only five of them would apply to the provisions that prohibit the trafficking in circumvention technologies. ${ }^{166}$

\subsubsection{US Case Laws on Ante-Circumvention Provisions}

Universal City Studios, Inc. v. Corley ${ }^{167}$ : The most significant DMCA-related case involves a suit brought by eight major motion picture studios against the defendants, who operated a Web-based publication. The defendants had posted, and encouraged others to copy and distribute, a decryption algorithm known as DeCSS. DeCSS allows users to crack or circumvent the technological measureCSS-which restricts unauthorized access to DVD video disks. The defendants also linked to other Websites where DeCSS was posted. The principal defense in the case was that the anti-trafficking provisions of Section 1201(a)(2) were unconstitutional because they violated the defendants' First Amendment right to free speech by means of the exchange of DeCSS source code.

The court of appeals specifically examined the question of whether circumvention of CSS was permitted where done to aid in a fair use of motion pictures on DVD videodisks. Interpreting Section 1201(c)(1), the court concluded that the DMCA

\footnotetext{
${ }^{166}$ See WIPO Standing Committee on Copyright and Related Rights, "Current Developments in the Field of Digital Rights Management", Tenth Session, November 3-5, 2003 , www.wipo.int/documents/en/meetings/2003/sccr/pdf/sccr_10_2.pdf , last visited 26 May 2004.

16773 F.3d 429 (2d Cir. 2001), aff'g Universal City Studios, Inc. v. Reimerdes, 111 F. Supp. 2d

346 (S.D.N.Y. 2000).
} 
targets the circumvention of digital protections through its anti-trafficking provisions, but does not concern itself with the use of the content after circumvention has occurred. It rejected the notion that Congress intended to permit "fair use" circumvention. Finally, the court disagreed with defendants" position that the DMCA was unconstitutional insofar as it eliminated the ability to make fair use of copyrighted works protected by access control; the court found that the fair use doctrine did not guarantee that anyone would have access to copyrighted material.

United States of America v. Elcom, Ltd. ${ }^{168}$ : Dmitry Sklyarov, a Russian programmer, was indicted for violating the DMCA's anti-trafficking provisions. As an employee of the Russian company Elcom, he created software that decrypted the Adobe eBook security software, which both allowed users to read eBooks in multiple formats and allowed them to copy eBooks. Elcom moved to dismiss the indictment, challenging the DMCA on various constitutional grounds, including that Section 1201(b) was unconstitutionally vague, that the section restricted the content of its speech and that it curtailed third parties' rights to engage in fair use of copyrighted material. In May 2002, the district rejected each of these claims and denied Elcom's motion. Echoing the decision in Corley, the court concluded that even if the DMCA directly regulated constitutionally protected expression, it did not affect the public's right to use either public domain or copyrighted works because it affects only the ability to access and use particular copies of those works.

\subsubsection{European Union on Technological Enforcement}

Article 6 of the Copyright Directive implements both Article 11 of the WCT and Article 18 of the WPPT. Like the DMCA, Article 6 applies to both circumventing acts and circumventing tools, and broadly applies to technological measures that control access as well as copyright.

Article 6(1) prohibits circumventing acts: Member States are directed to provide "adequate legal protection against the circumvention of effective technological measures."

Only acts carried out with the "knowledge" or reason to know that the objective of

circumvention is pursued are prohibited.

Article 6(2) covers circumvention tools (including services): Member States are directed to provide "adequate legal protection" against trafficking-as well as possession for commercial purposes-of tools that meet one of three tests. They are:

- promoted, advertised or marketed for the purpose of circumvention of; or

- have only a limited commercially significant purpose or use other than to circumvent; or - are primarily designed, produced, adapted or performed for the purpose of enabling or facilitating the circumvention of any effective technological measure. These tests are quite similar to those in the DMCA and, as such, contain similar uncertainties (e.g., the meaning of "primarily"). It should also be noted, however, that one of the recitals to the Copyright Directive

${ }^{168} 203$ F. Supp. 2d 1111 (N.D. Cal. 2002). 
suggests that national law may also go further than Article 6(2) and prohibit the "private possession" of products for circumvention.

The Copyright Directive builds on the DMCA's approach to defining "effective technological measures." Unlike the DMCA, however, it is this definition-and not separate provisions (along the lines of Section 1201(a) and 1201(b))-that establishes the broad scope of the anti-circumvention provisions as applying to both access and copyright control measures.

Article 6(3) defines technological measures to include any technology that "in the normal course of its operation, is designed to prevent or restrict acts, in respect of works or other subject matter, which are not authorized by law or the sui generis right provided for in Chapter III of Directive 96/9/EC [applicable to databases]." Accordingly, where a technological measure is used to ensure that the authorization of the rights holder is obtained before having access to or using a work, circumvention of the measure-by act or product-is prohibited. In this regard, the concept of "technological measures" is broader than that of the DMCA.

Article 6(3) also defines when a technological measure is "effective." A technological measure is "effective" where use of a work or subject matter is controlled by the rights holder through "an access control or protection process, such as encryption, scrambling or other transformation of the work or other subject-matter or a copy control mechanism, which achieves the protection objective." In defining the measures to be protected against circumvention as only those that "achieve the protection objective," the Article could be interpreted as stating that only those measures that are, in fact, "effective" shall be deemed to be "effective" for purposes of the Copyright Directive and implementing law. In addition, it is not clear whether an "effective" access control or protection process may only make use of "encryption, scrambling or other transformation" of the work," and whether any type of "mechanism" may be used for "copy control." Furthermore, the Article here uses the term "copy control" instead of "copyright control"; in doing so, the question has been raised as to whether technological measures that control non-copying uses of copyrighted material, such as public performances or distribution, actually fall within the scope of Article 6.

The Copyright Directive is broader than the DMCA because it also prohibits acts of circumventing copyright control measures and other acts not authorized by the rights holder.

Assume, for example, that a technological measure is used to condition access to and use of copyrighted content, and that access is made available to the user on the basis of an agreement that controls a person's subsequent use. If that person violates those usage conditions, that would be an "act not authorized by the right holder." The anti-circumvention provisions of the Copyright Directive would prohibit such an act. (In the United States of America, by contrast, breaching an agreement in this way might be an act of infringement under copyright, but not an act of circumvention outlawed by the DMCA.) The matrix of prohibitions in the Copyright Directive appears as follows ${ }^{169}$ :

\footnotetext{
${ }^{169}$ See WIPO Standing Committee on Copyright and Related Rights, "Current Developments in the Field of Digital Rights Management", Tenth Session, November 3-5, 2003, www.wipo.int/documents/en/meetings/2003/sccr/pdf/sccr_10_2.pdf, last visited 26 May 2004.
} 


\begin{tabular}{|l|l|l|}
\hline & Act of Circumvention & Circumvention Tools \\
\hline $\begin{array}{l}\text { Access Control } \\
\text { Technological Measure }\end{array}$ & Prohibited (Art. 6(1)) & Prohibited (Art. 6(2)) \\
\hline $\begin{array}{l}\text { Copyright Control } \\
\text { Technological Measure }\end{array}$ & Prohibited (Art. 6(1)) & Prohibited (Art. 6(2)) \\
\hline
\end{tabular}

\subsubsection{Limitations and Exceptions Provided in the EU Directives}

WIPO Standing Committee in its Report stated elaborately the limitations and exceptions provided in the EU Directives. The gist of the discussion is mentioned below.

Article 5 sets out exceptions and limitations on copyright rights that Member States may-but are not required to-provide with respect to the use of copyrighted materials.

(Indeed, various Member States do not provide for broad-based exemptions for private copying, for example.) Therefore, Article 5 and Article 6 work together as follows:

circumvention of technological measures is permitted where the act of doing so (or the trafficking in circumventing products themselves) is undertaken in order to benefit from these exceptions or limitations in national law. Thus, unlike the DMCA, where the exceptions in Section 1201 are essentially defenses to an action for circumvention, the Copyright Directive's approach is to suggest that a Member State may (or may not) permit certain underlying acts, acts that the technological measures are supposed to accommodate (whether on a voluntary basis, or otherwise). The acts that might be permitted are set out below.

Permitted Reproductions: Article 5 states that Member States may provide for exceptions in their national laws to the rights of reproduction (5(2)) and reproduction and communication (5(2) and (3)). These include:

- Reproductions on paper (photocopying), provided that rights holders receive fair compensation ${ }^{170}$;

- Reproductions by public libraries, educational establishments and museums, or archives, for non-commercial purposes ${ }^{171}$;

- Ephemeral recordings made by broadcasting organizations and associated $\operatorname{archiving}^{172}$;

- Reproductions by non-commercial institutions (such as hospitals and prisons), provided that rights holders receive fair compensation ${ }^{173}$;

\footnotetext{
${ }^{170}$ Article 5(2)(a), Copyright Directive.

${ }^{171}$ Article 5(2)(c).

172 Article 5(2)(d).

${ }^{173}$ Article 5(2)(e).
} 
- Uses for teaching or scientific research, for non-commercial purposes, where credit is given, if possible ${ }^{174}$;

- Non-commercial uses for persons with disabilities, where related to the disability and to the extent required ${ }^{175}$; and

- Uses for public security or reporting of governmental proceedings ${ }^{176}$.

\subsubsection{Rights -Management Information}

The WIPO Standing Committee Report briefly discussed about the rightsmanagement information available in the EU Copyright Directives. The Report stated that, Article 7 of the Copyright Directive separately requires that Member States provide for adequate legal protection against a person who "knowingly" removes or alters electronic "rights-management information" or distributes works from which such information has been removed or altered without authority. Such removal or alteration is prohibited if and to the extent that the person knows or has reason to know that by doing so he or she is inducing, enabling, facilitating or concealing an infringement of copyright, related rights or the sui generis database right.

"Rights-management information" is defined similarly to copyright management information under Section 1202 of the DMCA. It includes information that identifies or relates to the work, conditions of use and numbers or codes representing such information.

\subsection{Implementation of DRM}

The development, implementation, protection and use of Digital Rights Management (DRM) as a curbing measure raise a number of policy issues for national governments and international institutions, including the European Commission and WIPO. Some of these policy issues as identified by WIPO are as follows: implementation of WIPO treaties, effect of DRMs on copyright exceptions and limitations, DRMs and Private-Copying Levies, privacy and jurisdiction and applicable laws etc. ${ }^{177}$ The WIPO Standing Committee on Copyright and Related Rights observed that implementation of the WIPO Treaties was relatively rapid in the United States of America, Japan and Australia. It has been slower in the European Union, as the process of adopting the Copyright Directive has taken some time. Only two of the Member States (Greece and Denmark) met the December 22, 2002 deadline for transposition of the Copyright Directive into national law and till early August 2003, only five have incorporated Copyright Directive in their respective national law. A number of other major

\footnotetext{
${ }^{174}$ Article 5(3)(a).

175 Article 5(3)(b).

176 Article 5(3)(e).

177 See WIPO Standing Committee on Copyright and Related Rights, "Current Developments in the Field of Digital Rights Management”, Tenth Session, November 3-5, 2003, www.wipo.int/documents/en/meetings/2003/sccr/pdf/sccr_10_2.pdf, last visited 30 August 2004
} 
countries have not yet implemented the WIPO Treaties. Remarkable variations have been observed by the WIPO among the statutes of the implementing countries of the WIPO Treaties. ${ }^{178}$ Still today it is not apparently visible that the speed with which the WIPO Treaties have been implemented, or the variations in the implementing statutes, have had any measurable effect on the development or use of DRMs. It can be expected that in the course of time all the contracting parties will implement their treaty obligations. Then we will be able to discover that whether differences in implementation will have any meaningful effect on the deployment of DRMs or the Protection of content delivered through DRM solutions.

\footnotetext{
${ }^{178}$ Differences are apparent with respect to exceptions or limitations for Circumventing acts or products, anti-trafficking provisions and whether a device should be outlawed or permitted, depending on whether its "sole" or merely its "primary" purpose is circumvention. See Ibid, P.109.
} 


\section{Compatibility With Human Rights}

\subsection{Brief Introduction to the Interface}

Human Rights and Intellectual Property Law were strangers to each other for a long time. For the first time on November 9, 1998 a panel discussion on "Intellectual Property and Human Rights"179 took place in Geneva to mark the Fiftieth Anniversary of the Universal Declaration of Human Rights (UDHR). The World Intellectual Property Organization (WIPO) and the Office of the United Nations High Commissioner for Human Rights (OHCHR) jointly organized the discussion. In that discussion the panelists explored the complementarity of intellectual property rights and international human rights standards.

Scholars found two distinct approaches to the interface of human rights and intellectual property ${ }^{180}$. The first approach considers human rights and intellectual property as in fundamental conflict ${ }^{181}$. The scholars of the approach found strong intellectual property protection as undermining and therefore as incompatible with a broad spectrum of human rights obligations, especially in the area of economic, social, and cultural rights. The prescription that proponents of this approach advocate for resolving this conflict is to recognize the normative primacy of human rights law over intellectual property law in areas where specific treaty obligations conflict ${ }^{182}$.

\footnotetext{
${ }^{179}$ See Intellectual Property and Human Rights, A Panel Discussion to commemorate the $50^{\text {th }}$ Anniversary of the Universal Declaration of Human Rights, WIPO Publication No. 762(E), WIPO 1999.

${ }^{180}$ Human Rights an Intellectual Property: Conflict or Co-existence?, Professor Laurence Helfer, available at http://ssrn.com/abstract=459120, last visited 1 August 2004.
}

${ }^{181}$ See, e.g., Sub-Commission on the Protection and Promotion of Human Rights, Intellectual
Property Rights and Human Rights, Res. $2000 / 7$, E/CN.4/Sub/2/2000/L.20, preambular $₫ 11$
[hereinafter Resolution 2000/7] (stating that "actual or potential conflicts exist between the
implementation of the TRIPs Agreement and the realization of economic, social and cultural
rights"). Cited in Human Rights an Intellectual Property: Conflict or Co-existence?, Professor
Laurence Helfer, available at http://ssrn.com/abstract=459120, last visited 1 August
2004.

182 Ibid. (emphasizing "the primacy of human rights obligations over economic policies and agreements"). Statements by legal commentators and NGOs also advocate the primacy of human rights over economic agreements, including those relating to intellectual property rights. Notably, these assertions of primacy are not limited to juscogens or peremptory norms, which are hierarchically superior to other international law obligations. See, e.g., Robert Howse \& Makau Mutua, Protecting Human Rights in a Global Economy: Challenges for the World Trade Organization at *6 (Int'l Centre for Human Rts. \& Democratic Dev., Policy Paper, 2000) ("Human rights, to the extent they are obligations erga omnes, or have the status of custom, or of general principles, will normally prevail over specific conflicting provisions of treaties such as trade agreements.”); HIV/AIDS Legal Network \& AIDS Law 
The second approach to the intersection of human rights and intellectual property sees both areas of law as concerned with the same fundamental question: defining the appropriate scope of private monopoly power to give authors and inventors a sufficient incentive to create and innovate, while ensuring that the consuming public has adequate access to the fruits of their efforts. This school views human rights law and intellectual property law as essentially compatible, although often disagreeing over where to strike the balance between incentives, on the one hand and access on the other ${ }^{183}$.

One of the proponents of the second approach, i.e. compatibility of human rights with IP, opined that international human rights instruments in fact complement intellectual property law; for example, Article 15 of the International Covenant on Economic, Social and Cultural Rights (ICESCR) (Paragraph 1(c)) stipulates that everyone has the right:

"To benefit from the protection of the moral and material interests resulting from any scientific, literary or artistic protection of which he is the author."

States Parties not only have an obligation to respect this right, they are also to "... undertake to respect the freedom indispensable for scientific research and creative activity" and to "... recognize the benefits to be derived from the encouragement

Project, South Africa, TRIPs and Rights: International Human Rights Law, Access to Medicines, and the

Interpretation of the WTO Agreement on Trade-Related Aspects of Intellectual Property Rights at 2 (Nov. 2001), available at www.aidslaw.ca (asserting that because "States' binding legal obligations to realize human rights have primacy in international law," obligations in TRIPs "must be recognized as not binding to the extent there is a conflict with [states'] human rights obligations"). Cited in Human Rights an Intellectual Property: Conflict or Co-existence?, Professor Laurence Helfer, available at http://ssrn.com/abstract=459120, last visited 1 August 2004.

183 See, e.g., Intellectual Property and Human Rights: Report of the Secretary-General, ESCOR, Sub-Comm'n on the Promotion and Protection of Human Rights, 52nd Sess., Provisional Agenda Item 4, U.N. Doc. E/CN.4/Sub.2/2001/12 (2001) at 8 (submission by WTO asserting that existing international agreements permit states sufficient room to balance intellectual property and human rights standards, but noting that "[h]uman rights can be used - and have been and are currently being used - to argue in favour of balancing the system either upwards or downwards by means of adjusting the existing [intellectual property] rights or by creating new rights"); World Health Organization, Globalization, TRIPs and Access to Pharmaceuticals, WHO Policy Perspectives on Medicines, No. 3, WHO/EDM/2001.2 at 5 (Mar. 2001) [hereinafter WHO Policy Perspectives] (asserting that "[a]cess to essential drugs is a human right" but urging states to using existing "safeguards" within TRIPs to "enhance the affordability and availability" of patented medicines); Report of the High Commissioner, The impact of the Agreement on Trade-Related Aspects of Intellectual Property Rights on Human Rights, E/CN.4/Sub.2/2001/13, 11-12 (June 27, 2001) [hereinafter High Commissioner Report] (stating that " $\mathrm{t}]$ he balance between public and private interests found under article 15 [of the ICESCR] - and article 27 of the Universal Declaration - is one familiar to intellectual property law" but asserting that the key question "is where to strike the right balance"). Cited in Human Rights an Intellectual Property: Conflict or Co-existence?, Professor Laurence Helfer, available at http://ssrn.com/abstract=459120, last visited 1 August 2004. 
and development of international contracts and cooperation in the scientific and cultural fields" (paragraphs 3 and 4 of Article 15).

Article 19 of the International Covenant on Civil and Political Rights (ICCPR) prescribes that:

"Everyone shall have the right to freedom of expression; this right shall include freedom to seek, receive and impart information and ideas of all kinds, regardless of frontiers, either orally, in writing or in print, in the form of art or, through any other media of his choice."

States Parties to both the Covenants are obliged to submit periodic reports to the relevant International Committees outlining the legislative, administrative and other steps taken to ensure the enjoyment of, Inter alia, intellectual property rights and freedom of expression. In addition, the Commission on Human Rights' Special Rapporteur on the Right to Freedom of Opinion and Expression has responsibility for investigating and reporting on the implementation of freedom of expression in specific countries. Within the framework of the work of the Special Reapporteur, issues concerning the protection of intellectual property rights may be discussed and brought to international attention. ${ }^{184}$

Dr. Peter Darhos opined that the international document, which can perhaps be said to constitutionalize the human rights regime, is the Universal Declaration of Human Rights, 1948 (the UDHR) ${ }^{185}$. He further stated that the UDHR does not expressly refer to intellectual property rights, but Article 27.2 states, "Everyone has the right to the protection of the moral and material interests resulting from any scientific, literary or artistic production of which he is the author." At the same time Article 27.1 states that everyone has "the right freely to participate in the cultural life of the community, to enjoy the arts and to share in scientific advancement and its benefits." Article 27 thus carries with it a tension familiar to intellectual property law: the tension between rules that protect the creators of information and those that ensure the use and diffusion of information. The recognition of the interests of authors in the UDHR is complemented by the proclamation in Article 17.1 of a general right of property. This Article states that "[e]veryone has the right to own property" and 17.2 states that "[n]o one shall be arbitrarily deprived of his property." The implication of Article 17.2 is that states do have a right to regulate the property rights of individuals, but that they must do so according to the rule of law.

Some international human right instruments do recognize a general right of property or something close to it. The African Charter on Human and Peoples' Rights, 1981 in Article 14, guarantees the right to property, although it then goes on to recognize that that right may be encroached upon in the "interest of public need or in the general interest of the community". The American Convention on Human Rights, 1969, in Article 21.1, recognizes a right of property, a right which no one is to be deprived of "except upon payment of just compensation" (see Article 21.2). A right to property was not included in the European Convention of Human Rights and Fundamental Freedoms, 1950 because of controversy over its

\footnotetext{
${ }^{184}$ Opening Address, Mr. Brian Burdekin on behalf of Mrs. Mary Robinson, United Nations High Commissioner for Human Rights, Ibid note 146.

${ }^{185}$ See Dr. Peter Drahos, The Universality of Intellectual Property Rights: Origins and Developments, Ibid note 179.
} 
drafting, but a right to peaceful enjoyment of one's possessions was included in Article 1 of Protocol 1. That Article then goes on to recognize the right of a "State to enforce such laws as it deems necessary to control the use of property in accordance with the general interest." 186

The Sub-Commission on the Promotion and Protection of Human Rights declared intellectual property rights as human rights on August 17, 2000 (E/CN.4/Sub.2/2000/7) "subject to limitations in the public interest" (substantive paragraph 1$)^{187}$.

\subsection{Human Rights and International IP Treaties}

The "national treatment" is one of the basic principles of important international property right treaties like the Berne Convention and Paris Convention, which is based on principle of non-discrimination. The Principle of National Treatment has been explained in WIPO-Guide to the Berne Convention as Follows:

"This provision treats foreigners in the same way as nationals as regards the protection of their works. In other words, works, which have a country of origin ..., which is a Union Country, benefit, in all other Union Countries, from the same protection as the latter give to the works of their own nationals. For example, if the copyright in a work by a Senegalese author, published for the first time in the Ivory Coast, is infringed in France, this author and his successors in title must be treated in France as if the work were one made by a French author and published on French Territory."

Some of the most important provisions on non-discrimination are Article 2 of the UDHR, Article 2.2 of the International Covenant on Economic, Social and Cultural Rights (the ICESCR), Article 2.1 of the International Covenant on Civil and Political Rights (the ICCPR), Article 14 of the European Convention for the Protection of Human Rights and Fundamental Freedoms, Article 2 of the American Declaration of the Rights and Duties of Man, Article 1.1 of the American Convention on Human Rights and Article 2 of the African Charter on Human and Peoples' Rights. Equality before the law has been laid down as a human right in Article 7 of the UDHR, Articles 14.1 and 26 of the ICCPR, Article 24 of the American Convention on Human Rights, Article 2 of the American Declaration of the Rights and Duties of Man, and Article 3 of the African Charter on Human and Peoples' Rights. The provisions on non-discrimination apply to the rights recognized in the respective treaties and declarations.

How "national treatment" principle is incorporated in various international IP treaties has been shown below:

\section{(a) The Paris Convention}

Article 2.1 of the Paris Convention for the Protection of Industrial Property of 1967 (the Paris Convention) determines the personal scope of application on the basis of nationality: Beneficiaries of protection under the Convention are

\footnotetext{
186 Ibid.

${ }^{187}$ See Wend Wendland, "Intellectual Property and Human Rights Working Draft", P 11, Presented for the United Nations Committee on Economic, Social and Cultural Rights in Geneva, November 272000.
} 
nationals of any other country of the Union. In respect of nationals of other Union countries, no requirement as to domicile or establishment in the country where protection is claimed may be imposed (Article 2.2 of the Paris Convention). Article 3 of the Convention extends national treatment to nationals of countries outside the Union, provided that they are domiciled or have a real and effective industrial establishment in the territory of one of the countries of the Union. ${ }^{188}$

\section{(b) The Berne Convention}

Under the Berne Convention for the Protection of Literary and Artistic Works of 1971 (the Berne Convention), the personal scope of application has been laid down in Articles 4, 5 and $6^{189}$. Accordingly, the beneficiaries of national treatment are either nationals of one of the countries of the Berne Union, or those who have their habitual residence in one of these countries, or those who are not nationals of one of these countries, for their works first published in one of those countries (or simultaneously in a country outside the Union and a country of the Union). In respect of cinematographic works and works of architecture, additional possibilities to become eligible for protection are provided for under Article 4 of the Berne Convention: authors of cinematographic works are eligible if the maker of the work has his headquarters or habitual residence in one of the countries of the Union. Eligibility is also stated in respect of authors of works of architecture, which are erected in a country of the Union, and for authors of other artistic works, which are incorporated in a building, or other structure located in a country of the Union.

In sum, the criteria of eligibility are nationality or habitual residence of the author, or different points of attachment regarding the work, namely first publication, nationality of the maker of the cinematographic work and place of a building or other structure. The possibility to obtain the protection by the Berne Convention by first publication of a work in a country of the Union represents a remarkable extension of such possibilities for authors who are not nationals of a country of the Union nor have their habitual residence in such a country. This solution in particular goes far beyond that of the Paris Convention, where nationals from countries outside the Union may obtain protection only if they are domiciled or have their real and effective industrial establishment in the territory of one of the countries of the Union.

\section{(c) The Rome Convention}

Under the International Convention for the Protection of Performers, Producers of Phonograms and Broadcasting Organisations of 1961(the Rome Convention), different points of attachment for the protection of performers, phonogram producers and broadcasting organizations are provided for in Articles 4, 5 and 6

\footnotetext{
188 See on the question how to determine nationality in case of legal persons, to which the Paris Convention applies, Bodenhausen, Guide to the Application of the Paris Convention for the Protection of IndustrialProperty (Geneva, 1968), Article 2.1, note (b).

189 See on the question how to determine nationality in case of legal persons, to which the Paris Convention applies, Bodenhausen, Guide to the Application of the Paris Convention for the Protection of IndustrialProperty (Geneva, 1968), Article 2.1, note (b).
} 
of the Rome Convention ${ }^{190}$. For performers, nationality has not been chosen for practical reasons: very often, performing ensembles such as orchestras, bands or choirs include performers of different nationalities, which would render the application of the point of attachment of nationality too difficult. Instead of the nationality, the place of the performance is a point of attachment, as are the incorporation in a phonogram which is protected under Article 5 of the Rome Convention, and the broadcast of a performance which is not fixed on a phonogram if the broadcast is protected by Article 6 of the Rome Convention (Article 4 of the Rome Convention). Article 5 of the Rome Convention establishes, in respect of phonogram producers, the points of attachment of nationality, of first fixation and first publication; publication in a Contracting State within 30 days of first publication in a non-contracting State fulfills the requirement of first publication (Article 5.2 of the Rome Convention). In respect of broadcasting organizations, the points of attachment are either the headquarters of the organization or the transmission of the broadcast from a transmitter situated in another Contracting State ${ }^{191}$. Accordingly, also the Rome Convention covers only international situations: the relevant criterion must be related to another Contracting State than that in which protection is claimed.

(d) The TRIPS-Agreement

The Agreement on Trade-Related Aspects of Intellectual Property Rights of 1994 (the TRIPS Agreement) basically made it obligatory upon the Member States to incorporate the national treatment rules provided by the relevant Intellectual Property Conventions in their respective national legislation. The national treatment rules including the exceptions to them as provided under the relevant intellectual property conventions remained in the end untouched even by the most-favored nation clause in Article 4 of the TRIPS Agreement. The drafting techniques used are the following: Article 3.1, phrase 1 of the Agreement states the general principle that "each Member shall accord to the nationals of other Members treatment no less favorable than that it accords to its own nationals ...". In order to take account of the fact that nationality is not the only criterion, or even not at all a criterion for eligibility used in the conventions in order to determine the beneficiaries of protection, Article 1.3, phrase 2 of the TRIPS Agreement defines the term "nationals" by reference to "those natural or legal persons that would meet the criteria for eligibility for protection provided for in . . . " the relevant Conventions, “ . . . were all Members of the WTO members of those Conventions." This legal technique made it not necessary to spell out the relevant rules of the Conventions (Articles 2, 3 of the Paris Convention, Articles 3, 4 of the Berne Convention and Articles 4, 5 and 6 of the Rome Convention). In addition, TRIPS took over the exceptions to national treatment already provided in the relevant Conventions, such as the cases of reciprocity under the Berne Convention. In respect of the neighboring rights covered by the Rome Convention, the TRIPS Agreement chose the same approach of a narrow scope of

\footnotetext{
190 See a commentary on these articles in Masouyé, Guide to the Rome Convention and to the Phonograms Convention (WIPO Publ. No. 617E, Geneva, 1981) p. 26 et seq.

191 Article 6(1) of the Rome Convention. A Contracting State may notify that it will protect broadcasts only if both criteria are fulfilled, Article 6(2) of the Rome Convention.
} 
national treatment, which is limited to the rights provided under the TRIPS Agreement (which are, at the same time, minimum rights). In addition, the national treatment provisions of the Berne Convention have been included in the compliance clause of Article 9.1, phrase 1 of the TRIPS Agreement. In sum, the TRIPS Agreement has followed the national treatment provisions of the relevant intellectual property conventions.

(e) The WIPO Treaties, 1996

The WIPO Copyright Treaty, 1996 (the WCT) incorporated the rules on national treatment of the Berne Convention. According to the Article 1 of the WCT it is a special agreement within the meaning of Article 20 of the Berne Convention, which requires that the special agreement does not contain any provision contrary to the Berne Convention. Accordingly, Article 3 of the WCT obliges Contracting Parties to apply mutatis mutandis the relevant provisions of the Berne Convention dealing with national treatment (Articles 2 - 6 of the Berne Convention). An Agreed Statement explains how to understand certain notions of Articles 2 - 6 of the Berne Convention in applying them to the WCT.

Article 4 of the WIPO Performances and Phonograms Treaty, 1996 (the WPPT) again follows the basic approaches of the Rome Convention and the TRIPS Agreement. Regarding the eligibility for protection, it also, like TRIPS, uses the word "nationals" (of other Contracting Parties) and defines this word by a reference to the criteria for eligibility for protection provided under the Rome Convention, " ... were all the Contracting Parties to this Treaty Contracting States of that Convention" (Article 3.2, phrase 1 of the WPPT). Accordingly, Articles 4 and 5 of the Rome Convention have to be applied as criteria for eligibility for protection under the WPPT.

Regarding the scope of national treatment, Article 4.1 of the WPPT follows in principle the narrow approach of the Rome Convention and the TRIPS Agreement. It is even clearer than the Rome Convention, since it is limited explicitly to the "exclusive rights specifically granted in this Treaty" (as opposed to the "protection specifically guaranteed and their limitations specifically provided for" in the Rome Convention) and covers, as the only remuneration right, the right for secondary uses under Article 15 of the WPPT. Accordingly, any other remuneration rights, such as those for private copying, are clearly not covered by the national treatment provision of Article 4 of the WPPT. The only provision of material reciprocity is Article 4.2 of the WPPT, which corresponds largely to Article 16.1(a)(iv) of the Rome Convention. It allows the application of material reciprocity in a case where another Contracting Party makes use of the reservations permitted by Article 15.3 of the WPPT in relation to the remuneration right for secondary uses of phonograms.

In sum, the more recent treaties dealing with intellectual property rights - and even those which are larger trade treaties - have continued to not only make national treatment one of their main principles, but also to rely on the provisions of the Conventions as far as they relate to the criteria for eligibility for protection, to the scope of national treatment and the exceptions thereto. 


\subsection{Human Rights and Copyrights}

We have seen at the beginning of this chapter that Article 19 of the ICCPR provides for freedom of expression which includes freedom to seek, receive and impart information and ideas of all kinds, regardless of frontiers, either orally, in writing or in print, in the form of art or, through any other media of choice. Generally copyright seems to be an impediment to this right. It's a difficult task to strike a balance between the exclusive rights of the copyright owner and the right to freedom of expression. In order to see how far this balance has been achieved we shall now examine the International copyright laws as well as national jurisdictions.

\subsubsection{International Copyright Laws}

If we carefully examine the International laws on copyright like Berne Convention, TRIPS Agreement and WIPO Treaties we would find that Member States of these Conventions are relentlessly trying to strike a balance between these apparently two conflicting notions.

(a) The Berne Convention

Article 2 (8) of the Berne Convention states "The protection of this Convention shall not apply to news of the day or to miscellaneous facts having the character of mere items of press information." The basic aim behind not to give copyright protection to the news item is to ensure the right to information of the people. Article 2 bis of the Convention runs as follows:

“ 1) It shall be a matter for legislation in the countries of the Union to exclude, wholly or in part, from the protection provided by the preceding Article political speeches and speeches delivered in the course of legal proceedings.

(2) It shall also be a matter for legislation in the countries of the Union to determine the conditions under which lectures, addresses and other works of the same nature which are delivered in public may be reproduced by the press, broadcast, communicated to the public by wire and made the subject of public communication as envisaged in Article 11 bis (1) of this Convention, when such use is justified by the informatory purpose.

(3) Nevertheless, the author shall enjoy the exclusive right of making a collection of his works mentioned in the preceding paragraphs."

So the right to freedom of expression is to the same extent reflected in these provisions of the Convention. 
Articles 10 and 10 bis of the Berne Convention provide the provisions for imposing limitations on the author's exclusive rights to exploit his work in order to meet the "public for information" $"$. Article 10 and 10 bis are as follows: Article $10^{193}$

"(1) It shall be permissible to make quotations from a work which has already been lawfully made available to the public, provided that their making is compatible with fair practice, and their extent does not exceed that justified by the purpose, including quotations from newspaper articles and periodicals in the form of press summaries.

(2) It shall be a matter for legislation in the countries of the Union, and for special agreements existing or to be concluded between them, to permit the utilization, to the extent justified by the purpose, of literary or artistic works by way of illustration in publications, broadcasts or sound or visual recordings for teaching, provided such utilization is compatible with fair practice.

(3) Where use is made of works in accordance with the preceding paragraphs of this Article, mention shall be made of the source, and of the name of the author, if it appears thereon."

Article 10 bis $^{194}$

1) It shall be a matter for legislation in the countries of the Union to permit the reproduction by the press, the broadcasting or the communication to the public by wire, of articles published in newspapers or periodicals on current economic, political or religious topics, and of broadcast works of the same character, in cases in which the reproduction, broadcasting or such communication thereof is not expressly reserved. Nevertheless, the source must always be clearly indicated; the legal consequences of a breach of this obligation shall be determined by the legislation of the country where protection is claimed.

(2) It shall also be a matter for legislation in the countries of the Union to determine the conditions under which, for the purpose of reporting current events by means of photography, cinematography, broadcasting or communication to the public by wire, literary or artistic works seen or heard in the course of the event may, to the extent justified by the informatory purpose, be reproduced and made available to the public.

If we consider the text of Article 10 then we would find that the Convention puts three limitations on the licence to quote. In the first place the work from which the extract is taken must have been lawfully made available to the public. Unpublished manuscripts or even works printed for a private circle may not, it is felt, be freely quoted from; the quotation may only be made from a work intended for the public in general. This provision applies to the works available under compulsory licence.

Secondly, quotation must be "compatible with fair practice". This concept, introduced at the Stockholm Revision (1967), appears a number of timers in the Convention. It implies an objective appreciation of what is normally considered admissible. Whether there was fairness or malafide intention would be determined

\footnotetext{
192 See WIPO - Guide to the Berne Convention, P. 58, WIPO (1978).

${ }^{193}$ See Berne Convention, Article 10, WIPO Publication no. 223 (E).

${ }^{194}$ See Berne Convention, Article 10bis, WIPO Publication no. 223 (E).
} 
by the courts, which would consider the size of the extract and then where it is used, and, particularly the extent to which, if any, the new work, by competing with the old, cuts in upon its sales and circulation, etc.

In the third place, the quotation must only be to the extent "justified by the purpose". This is also to be determined by the courts. For example, the writer of a work of literature or history who, illustrates his theme with few quotations cannot be blamed or sued; on the other hand if he seems to use the extracts from others' works in bad faith, and without any relevance to his subject, the court may decide that the quotation is not lawful ${ }^{195}$.

The aforementioned considerations sufficiently explained the effort of making balance between freedom of expression and author's exclusive rights to exploit his intellectual creations.

But one criticism against the Berne Convention is that Article $19^{196}$ of the convention provides that a country of the Union shall not be precluded from the making of a claim to the benefit of any greater protection, which may be granted by legislation of that country.

The human rights proponents claim that the Berne Convention should set the maximum standard of protection in order to be preserved the right to freedom of expression.

\section{(b) The TRIPS Agreement}

Article 9 paragraph 2 of the TRIPS Agreement provides, "Copyright protection shall extent to expressions and not to ideas, procedures, methods of operation or mathematical concepts as such." This provision is conducive to the freedom of expression. Because only expressions of literary works are protected not ideas, which would be convenient to seek, receive and impart information.

Article 10 paragraph $1^{197}$ of the TRIPS Agreement protects computer programs as literary works under the Berne Convention. Therefore all the aforementioned provisions of the Berne Convention are applicable to the Computer programs also. This means under specific circumstances provided in the Convention the exclusive rights of the author of the computer program could be derogated.

Article 13 of the TRIPS Agreement provides, " Members Shall confine limitations or exceptions to exclusive rights to certain special cases which do not conflict with a normal exploitation of the work and do not unreasonably prejudice the legitimate interests of the right holder. ${ }^{, 198}$ By this provision TRIPS made it obligatory to Members to impose limitations to exclusive rights. Though the language is not very clear and specific but still we find a week effort on the part of TRIPS to provide provisions for keeping up freedom of expression.

\footnotetext{
${ }^{195}$ See Guide to the Berne Convention, P. 59, WIPO (1978).

${ }^{196}$ Article 19 of the Berne Convention runs "The provisions of this Convention shall not preclude the making of a claim to the benefit of any greater protection which may be granted by legislation in a country of the Union.".

${ }^{197}$ Article 10 Paragraph 1 of the TRIPS Agreement runs, "Computer programs, whether in source of object code, shall be protected as literary works under the Berne Convention (1971).

${ }^{198}$ See WIPO Publication no. 223 (E), P. 21.
} 
The main criticism against TRIPS is that it provided a minimum standard for the Members and set no limit for imposing maximum intellectual property protection. Professor Laurence Helfer in his article Human Rights and Intellectual Property : Conflict or Coexistence? mentioned that the new intersection between human rights and intellectual property - the articulation of "maximum standards" of intellectual property protection. Treaties from Berne to Paris to TRIPS are all concerned with articulating "minimum standards." ${ }^{199}$ But higher standards are not considered problematic, and nothing in the treaties prevents governments from enacting more stringent domestic intellectual property laws, or from entering into agreements that enshrine such standards. ${ }^{200}$ Indeed, since TRIPS entered into force, the United States and the EC have negotiated so-called "TRIPS plus" bilateral agreements with many developing countries. These treaties contain intellectual property rules that impose higher standards of protection than TRIPs requires. The U.N. High Commissioner for Human Rights and the WHO have voiced strong objections to TRIPS plus treaties on human rights grounds. ${ }^{201}$ Together with the particularization of soft law ${ }^{202}$ norms these objections may, for the first time, begin to impose a ceiling on the upward drift of intellectual property standards that has accelerated over the past few decades.

\section{(c) WIPO Copyright Treaty}

WIPO Copyright Treaty (WCT) and WIPO Performances and Phonograms Treaty (WPPT) together are popularly known as the Internet Treaties. If we go through the preamble of WCT we would find the fundamental objects of the treaty. The relevant portion of the preamble is as follows:

"Recognizing the profound impact of the development and convergence of information and communication technologies on the creation and use of literary and artistic works,

Emphasizing the outstanding significance of copyright protection as an incentive for literary and artistic creation,

\footnotetext{
199 See, e.g., TRIPs Agreement, art. 1(1) ("Members may, but shall not be obliged to, implement in their law more extensive protection than is required by this Agreement."); Rochelle Cooper Dreyfuss \& Andreas F. Lowenfeld, Two Achievements of the Uruguay Round: Putting TRIPS and Dispute Settlement Together, 37 Va. J. Int'l L. 275, 295-304 (1997) (emphasizing the importance of TRIPs' minimum standards framework).
}

200 See GRAIN, “TRIPs-plus" Through the Back Door: How Bilateral Treaties Impose Much Strong rules for IPRs on Life than the WTO (July 2001) (describing bilateral agreements negotiated by the United States and EC that require developing countries to adopt more stringent intellectual property rules than those found in TRIPs).

201 See Ibid F.N. 181.

202 Comm. on Hum. Rts. Res. 2001/33 (Apr. 23, 2001); Comm. on Hum. Rts. Res. 2002/32 (Apr. 22, 2002); see also Access to Medication in the Context of Pandemics such as HIV/AIDS, Tuberculosis and Malaria, Comm. on Hum. Rts. Res. 2003/29 (Apr. 22, 2003). See also Committee on Economic, Social and Cultural Rights, Substantive Issues Arising in the Implementation of the International Covenant on Economic, Social and Cultural Rights, Followup to the day of general discussion on article 15.1(c), Nov. 25, 2001, Statement on Human Rights and Intellectual Property, E/C.12/2001/15 19 4, 11 (14 Dec. 2001). 
Recognizing the need to maintain a balance between the rights of authors and the larger public interest, particularly education, research and access to information, as reflected in the Berne Convention," 203

This clearly shows the contracting parties intention to achieve a balance between the author's exclusive rights to exploit his intellectual creation and larger public interest.

Article 10 of WCT provides for optional provision for the contracting parties to incorporate in their national legislation limitations or exceptions to the author's rights under special cases. Article 10 of the Treaty runs as follows:

“(1) Contracting Parties may, in their national legislation, provide for limitations of or exceptions to the rights granted to authors of literary and artistic works under this Treaty in certain special cases that do not conflict with a normal exploitation of the work and do not unreasonably prejudice the legitimate interests of the author.

(2) Contracting Parties shall, when applying the Berne Convention, confine any limitations of or exceptions to rights provided for therein to certain special cases that do not conflict with a normal exploitation of the work and do not unreasonably prejudice the legitimate interests of the author.",204

The aforementioned provisions indicates that whilst in general, copyright comprises a set of exclusive rights, there are opportunities to modify them by, on occasions, allowing free use of copyright works, or use in exchange for fair compensation; but all such modifications are subject to the three-step test provided by Article 13 of the TRIPS Agreement, i.e. such modifications must be for special cases, must not be conflicting with the normal exploitation of the work and must not unreasonably prejudice the legitimate interests of the author. This has been the approach taken, for example, in the recently adopted European Directive on Copyright and Related Rights in the Information Society (May 2001).

\subsubsection{National Jurisdictions}

\subsubsection{U.S.A.}

The doctrine of fair use has been incorporated in the following way in the US Copyright Act:

“\$107. Limitations on exclusive rights: Fair use

Notwithstanding the provisions of sections 106 and 106A, the fair use of a copyrighted work, including such use by reproduction in copies or phonorecords or by any other means specified by that section, for purposes such as criticism, comment, news reporting, teaching (including multiple copies for classroom use), scholarship, or research, is not an infringement of copyright. In determining whether the use made of a work in any particular case is a fair use the factors to be considered shall include--

(1) the purpose and character of the use, including whether such use is of a commercial nature or is for nonprofit educational purposes;

(2) the nature of the copyrighted work;

(3) the amount and substantiality of the portion used in relation to the

\footnotetext{
${ }^{203}$ See Preamble of WIPO Copyright Treaty (WCT) (1996), WIPO Publication No. 226 (E).

${ }^{204}$ See WIPO Copyright Treaty (WCT) (1996), WIPO Publication No. 226 (E).
} 
copyrighted work as a whole; and

(4) the effect of the use upon the potential market for or value of the copyrighted work.

The fact that a work is unpublished shall not itself bar a finding of fair use if such finding is made upon consideration of all the above factors." 205

The doctrine of fair use developed over the years as courts tried to balance the rights of copyright owners with society's interest in allowing copying in certain, limited circumstances. This doctrine has at its core a fundamental belief that not all copying should be banned, particularly in socially important endeavours such as criticism, news reporting, teaching, and research.

In the context of computer technologies, the fair use doctrine is often used in the context of reverse engineering. Under trade secret principles, it is generally accepted to "reverse engineer" a product to determine how the product works. Reverse engineering may involve analyzing circuit board layouts, "peeling" back a integrated circuit chip, or decompiling computer software. However, it is impossible to decompile software and then analyze the results without making a copy (or a derivative work) of the software. Courts have sometimes held that the making of these copies in the context of reverse engineering is a fair use and is not copyright infringement. ${ }^{206}$

The DMCA was enacted in 1998 to implement the World Intellectual Property Organization Copyright Treaty ("WIPO Treaty"), which requires contracting parties to "provide adequate legal protection and effective legal remedies against the circumvention of effective technological measures that are used by authors in connection

with the exercise of their rights under this Treaty or the Berne Convention and that restrict acts, in respect of their works, which are not authorized by the authors concerned or permitted by law." 207

The DMCA contains exceptions for schools and libraries that want to use circumvention

technologies to determine whether to purchase a copyrighted product, 17 U.S.C. $\S$ 1201(d); individuals using circumvention technology "for the sole purpose" of trying to achieve "interoperability" of computer programs through reverseengineering, id. § 1201(f); encryption research aimed at identifying flaws in encryption technology, if the research is conducted to advance the state of knowledge in the field, id. $\S 1201(\mathrm{~g})$; and several other exceptions. ${ }^{208}$

In Universal City Studios, Inc. v. Reimerdes ${ }^{209}$, one of the first cases to test the bounds of the DMCA, a federal district court in New York enjoined the owners of a website from posting or electronically linking to a software program designed to

\footnotetext{
${ }^{205}$ See 17 USC 107, Limitations on exclusive rights: Fair Use, Bitlaw, available at www.bitlaw.com/source/17usc/107.html/, last visited 4 August 2004.

${ }^{206}$ See Bitlaw , available at www.bitlaw.com/source/17usc/107.html/, last visited 4 August 2004.

207 See UNIVERSAL CITY STUDIOS, INC. v. CORLEY, 273 F.3d 429 (2nd Cir. 2001).

${ }^{208}$ Ibid.

${ }^{209} 111$ F.Supp.2d 294.
} 
decrypt the technological copyright protection encoded in digital versatile discs (DVDs) $^{210}$. In this case The District Court, Kaplan, J., held that: (1) posting decryption software violated DMCA provision prohibiting trafficking in technology that circumvented measures controlling access to copyrighted works; (2) posting hyperlinks to other web-sites offering decryption software violated DMCA; (3) DMCA anti-trafficking provision was content-neutral as applied to computer program; (4) DMCA did not violate First Amendment as applied to defendants and decryption software; (5) defendants failed to establish antitrafficking provision was overly broad on grounds that it prevented noninfringing fair use of movies; (6) application of anti-trafficking provision to enjoin defendants from hyper-linking to other web-sites offering decryption software did not violate First Amendment; and (7) plaintiffs were entitled to injunction enjoining defendants from posting decryption software or hyperlinking to other web-sites that made Software available.

The Appellate Court in Universal City Studios, INC. v. Corley ${ }^{211}$ mostly supported Judge Kaplan's view taken in Universal City Studios, Inc. v. Reimerdes. The Appellate Circuit Court held that Digital Millennium Copyright Act (DMCA) does not prohibit the "fair use" of information just because that information was obtained in a manner made illegal by the DMCA. 17 U.S.C.A. $\S$ 1201(c)(1). The Judge also referred the legislative history of the DMCA that the legislative history of the enacted bill makes quite clear that Congress intended to adopt a "balanced" approach to accommodating both piracy and fair use concerns, eschewing the quick fix of simply exempting from the statute all circumventions for fair use. The Appellants contend that the DMCA, as applied by the District Court, unconstitutionally "eliminates fair use" of copyrighted materials. The Court rejected the Appellants contention on the following reasons:

(a) The Supreme Court has never held that fair use is constitutionally required.

(b) The Appellants do not claim to be making fair use of any copyrighted materials, and nothing in the injunction prohibits them from making such fair use. They are barred from trafficking in a decryption code that enables unauthorized access to copyrighted materials.

(C) The District Court properly noted, to whatever extent the antitrafficking provisions of the DMCA might prevent others from copying portions of DVD movies in order to make fair use of them, "the evidence as to the impact of the antitrafficking provision[s] of the DMCA on prospective fair users is scanty and fails adequately to address the issues." Universal I, 111 F.Supp.2d at 338 n. 246.

(d) The Appellants have provided no support for their premise that fair use of DVD movies is constitutionally required to be made by copying the original work in its original format. The judge further explained this point stating that the DMCA does not impose even an arguable limitation on the opportunity to make a variety of traditional fair uses of DVD movies, such

\footnotetext{
${ }^{210}$ See 2001 Harvard Law Review Association in West Law.

${ }^{211}$ For details of the case please see P.32.
} 
as commenting on their content, quoting excerpts from their screenplays, and even recording portions of the video images and sounds on film or tape by pointing a camera, a camcorder, or a microphone at a monitor as it displays the DVD movie. The fact that the resulting copy will not be as perfect or as manipulable as a digital copy obtained by having direct access to the DVD movie in its digital form, provides no basis for a claim of unconstitutional limitation of fair use.

The aforesaid two cases sufficiently explained the American position regarding fair use and Freedom of expression.

\subsubsection{United Kingdom}

The Copyright, Designs and Patents Act 1988 of UK which incorporated the E.C. Software Directives disclosed the following special permitted acts for computer programs $^{212}$ :

viii. decompilation of computer programs;

ix. making back-up copies of computer programs; and

$\mathrm{x}$. making copies of adaptations of computer programs.

Permitted acts that do not require the permission of the rightsholder and may not be held to infringe copyright under CDPA can be divided into three groups:
A. Fair Dealing
B. Library and Archive privilege
C. Other educational exemptions

\section{A. Fair Dealing ${ }^{213}$}

This applies particularly but not exclusively to the 'restricted act' of copying. There is no precise definition and the courts ultimately make interpretation. However, it essentially allows limited copying without permission provided it is 'fair' and the commercial interests of the rights holder are not damaged. Fair Dealing applies principally to literary, artistic, dramatic and musical works, for films, sound recordings, computer software etc. it may apply in more limited circumstances. It is not so much a right but a defence in law. Some rightsholders have issued guidelines on what is considered 'fair', for example in terms of how much may be copied of a book. Fair Dealing covers material in digital/electronic form, however databases require caution, as Database Right (as opposed to copyright) does not permit Fair Dealing as a defence for copying in all circumstances, for example not for Criticism and Review. In addition to Fair Dealing there is a general statutory exemption for 'insubstantial use', where the amount copied and its significance is so small as to be of negligible consequence to the rights holder. Again there is no precise definition but note that a very small part of a work may be of great significance to the whole. Unlike Fair Dealing this exemption extends to a wider range of purposes.

The principal purposes for which the Fair Dealing defence may be used are:

\footnotetext{
212 For details see Ibid sub section 1.6 at P 19.

${ }^{213}$ See www.jisclegal.ac.uk/ipr/fairdealings.htm?/name=lis-fair , last visited 7 August 2004.
} 
Research and Private Study. (Note that many commentators feel these two should be separated. It excludes sound recordings and films in both cases.)

Criticism and Review.

News Reporting. Photographs are excluded from this.

A key point is that an individual may only normally make one copy of an item under this defence, unless it can be shown to be 'fair' to do more, which is difficult. A second is that it does not cover use of the material for teaching. With regard to databases note that Fair Dealing does not apply for Research and Private Study if the copying is for commercial purposes.

In addition to the above the defence of 'incidental inclusion' can be used where relevant. For example a photograph may include accidentally a work of art. The work 'copied' must not be the subject or essential to the work in which it is contained. Music however must never be copied incidentally or as background unless permission is granted. For example a video or film shot in a bar might catch a CD being played at the time of filming. It is a condition of the Fair Dealing defence that the source of the work is acknowledged in all cases.

\section{B. Library and Archive privilege ${ }^{214}$}

The CDPA allows certain normally restricted actions to be carried out under this 'exception'. It is a right not a defence in law. Librarians and 'users' can still make copies under Fair Dealing however but not both. The privilege only allows the making of single copies, essentially for the purpose of research and private study. The right is largely restricted to non-profit libraries and archives and there are certain condition's attached. It does not apply to the making of electronic copies, which may have implications for Inter Library Loans and other services. Copies may be made of items for archival purposes under certain circumstances. For example the replacement of an archive copy. Library and Archive privilege does not extend to computer software. There are special rules for unpublished works.

\section{Other Educational Exemptions}

There is a general educational exemption that allows the copying of very restricted

amounts of material in specific circumstances.

\subsection{Case Law}

Article 10 of the European Convention of Human Rights (ECHR) Specifically guarantees the right to freedom of expression which has been reflected in the permitted act provisions of $\mathrm{CDPA}^{215}$ The complex relationship between the defences of fair dealing and public interest, on the one hand, and the right of the freedom of expression, on the other, has been addressed in recent case law and is referred as follows:

In Pro Sieben Media AG v Carlton UK Television $L t d^{216}$, the plaintiff secured the exclusive right to broadcast an interview with $M$ in Germany who became pregnant with octuplets in or about March 1996. The defendant had broadcast a programme which included a 30 -second sequence taken from the interview. The

\footnotetext{
214 See Ibid F.N. 212.

215 See Gillian Davies, Copyright and the Public Interest, P. 53, Sweet and Maxwell (2002).

${ }^{216}$ [1999] 1 WLR 605.
} 
plaintiff brought an action for copyright infringement and the defendant relied on the fair dealing defence for criticism or review. At first instance, the judge held that the defence failed principally for lack of sufficient acknowledgement of the author of the original programme and did not decide whether the use was fair dealing. The Court of Appeal reversed the decision with finding that there had been sufficient acknowledgement and that the defence of fair dealing did apply to the use of the 30-second extract. The Appellate Court stated that the permitted acts under the CDPA are all directed to achieving a proper balance between protection of the rights of a creative author and the wider public interest and that free speech is a very important part of that wider public interest.

But in Hyde Park Residence Ltd. V. Yelland (Hyde Park) ${ }^{217}$ a newspaper published some still photographs, taken on a security camera, of a visit by Diana, Princes of Wales, and Dodi Fayed, to Villa Windsor in Paris, on the day prior to their deaths in a car accident. The stills had been stolen by a security guard and sold to the newspaper, which published them more than a year later. The Trial Court upheld the defendant's fair dealing claim. But the Appellate Court reversed the decision concluding that the defence of fair dealing could not succeed. The Appellate Court stated that it is not believable that a fair minded and honest person would pay for the dishonestly taken driveway stills and publish them in a newspaper knowing that they had not been published or circulated. The Appellate Court also found that the extent of the use was excessive.

\subsubsection{Bangladesh}

The Copyright Act, 2000 (Act no. 28 of 2000) was enacted on 18 July 2000 in order to implement the provisions of the TRIPS Agreement and to make the copyright law up-to-date. The present Copyright Act provided for the fair use exception in section 72 of the Act. Basically the following acts have been exempted from copyright infringement:

i. Fair dealing with a literary, dramatic, musical or artistic work for the purposes of research for a non-commercial purpose does not infringe any copyright in the work;

ii. Fair dealing with a work for the purpose of criticism or review, of that or another work or of a performance of a work, does not infringe any copyright in the work;

iii. Fair dealing with a literary, dramatic, musical or artistic work for the purpose of reporting current events in newspaper, magazine or periodicals or broadcasting or movie or photography does not infringe any copyright in the work;

iv. Reproduction of any literary, dramatic, musical or artistic work for judicial proceedings or for the reporting of judicial proceedings;

$\mathrm{v}$. Reproduction or adaptation of a literary, dramatic, musical or artistic work in the course of instruction or of preparation for instruction by teacher or student for only educational purpose; and

vi. Copying or adaptation by a lawful user of a copy of a computer program from that copy for the purpose of using the program for which it was supplied or to make any back up copy of it for temporary protection from loss, destruction or damage.

${ }^{217}$ But see Gillian Davies, Copyright and the Public Interest, P. 61, Sweet and Maxwell (2002). 
Since the copyright law relating to computer program is recently enacted therefore, we do not have any reliable case law at present in this respect.

\subsection{Human Rights and Software Patenting}

Article 15.1(c) of the ICESCR Provides that:

"The right of everyone to benefit from the protection of the moral and material interests resulting from any scientific, literary or artistic production of which he is the author."

From this provision it can be derived that to be consistent with human rights norms in order to get patent protection a subject matter must meet the following considerations $^{218}$ :

(i) Intellectual property rights must be consistent with the understanding of human

dignity in the various international human rights instruments and the norms defined therein;

ii) Intellectual property rights related to science must promote scientific progress and access to its benefits;

(iii) Intellectual property regimes must respect the freedom indispensable for scientific research and creative activity;

(iv) Intellectual property regimes must encourage the development of

international contacts and cooperation in the scientific and cultural fields.

The European Union provides one potential model relevant to the first point. Article 53(a) of the European Patent Convention specifically stipulates that patents should not be granted for inventions "the publication or exploitation of which would be contrary to 'ordre public' or morality." Several provisions of a recent Directive of the European Parliament and of the Council on the legal protection of biotechnological inventions reiterate this principle. The Directive also excludes inventions from patentability, which offend against human dignity, and ethical and moral principles recognized in member states ${ }^{219}$.

In order to obtain a patent the inventor must disclose the invention. This condition ensures the dissemination of information, which enriches the store of publicly available knowledge and promotes further innovation by other inventors. The inventor gets exclusive rights in lieu of an extensive dissemination of the inventive steps, by which society at large benefits because the protected invention can then be used as a basis for further creative and inventive works ${ }^{220}$. Article 29.1 of the TRIPS Agreement requires that an application for a patent shall

\footnotetext{
${ }^{218}$ See AR Chapman, A Human Rights Perspective on Intellectual Property, Scientific Progress, and Access to the Benefits of Science, P138, Intellectual Property and Human Rights, A Panel Discussion to commemorate the $50^{\text {th }}$ Anniversary of the Universal Declaration of Human Rights, WIPO Publication No. 762(E), WIPO 1999.

${ }^{219}$ See "Directive 98/44/EC of the European Parliament and of the Council of July 6, 1998, paragraphs. 37-40, on the legal protection of biotechnological inventions", Official Journal of the European Communities, 30.7.98, L213/16.

${ }^{220}$ See Wend Wendland, "Intellectual Property and Human Rights Working Draft", P 5, Presented for the United Nations Committee on Economic, Social and Cultural Rights in Geneva, November 272000.
} 
disclose the invention in a manner sufficiently clear and complete for the invention to be carried out by others. The resulting information, which is stored and classified in patent documentation, is accessible to anyone, including to those in countries where a patent has not been sought ${ }^{221}$. Therefore, in order to obtain a patent on software, which fulfills the criteria of a patent, the inventor must disclose his invention and which would be the basis of further creative and inventive works.

Most of the industrialized countries support that strong intellectual property provisions promote growth and a strong domestic economy. Developing countries are against the stringent application of the patent law. Their opposition is based on three factors: (1) the benefits of an intellectual property system tend to be long term and tenuous; (2) in the short-term, intellectual property protection increases the cost of development, with the patents awarded and resulting payments for the use of these technologies going primarily to foreign multi-national corporations; and (3) few of these countries have the requisite infrastructure to uphold strong patent systems. Thus developing countries sometimes accuse former colonial countries and multinational corporations of seeking to impose "technological colonialism." 222

But software patenting would be rather convenient for a developing country like Bangladesh. This country has more than 200 software houses and data-entry centres and numerous computer shops. At present, there are around $20-30$ Bangladeshi software developers with foreign clients, some of which are $100 \%$ export orientated. Several years ago, the government of Bangladesh identified software as having important export potential. The total amount of software and IT-services exports is currently estimated at a maximum of $\$ 30$ million per year $^{223}$.

\subsection{Scope of Getting Right Balance}

An objective of intellectual property protection is to promote long term public interest by means of providing exclusive rights to right holders for a limited duration of time. After the expiration of the term of protection, protected works and inventions fall into the public domain and anyone is free to use them without prior authorization by the right holder ${ }^{224}$. An important balance between IP rights and public interest is a careful definition of protectable subject matter.

\footnotetext{
${ }^{221}$ See Protection of Intellectual Property Under the TRIPS Agreement, Secretariat of the World Trade Organization, available at www.wto.org, last visited 9 August 2004.

${ }^{222}$ A. E. Carroll, "A Review of Recent Decisions of the United States Court of Appeals for the Federal Circuit: Comment: Biotechnology and the Global Impact of U.S. Patent Law: Not Always the Best Medicine:," The American University Law Review (1995), pp. 2464-2466.

223 See Paul Tjia, "The Software Industry in Bangladesh and its Links to The Netherlands", available at www.ejisdc.org, last visited 9 August 2004.
}

\footnotetext{
${ }^{224}$ See Protection of Intellectual Property Under the TRIPS Agreement, Secretariat of the World Trade Organization, available at www.wto.org, last visited 9 August 2004.
} 
For example copyright protection does not cover any information or ideas contained in a work; it only protects the original way that such information and ideas have been expressed in a work ${ }^{225}$. As regards patents, the basic conditions imposed in the TRIPS Agreement are that for an invention to be patentable it must be new, involve an inventive step and be capable of industrial application $^{226}$. Moreover the Agreement recognizes the importance of ethical and other considerations by allowing a country, even where an invention fulfills the normal conditions of patentability, to refuse to grant a patent if the commercial exploitation of the invention is prohibited on grounds of public order or morality, including if its exploitation might be dangerous to life or health or seriously prejudicial to the environment ${ }^{227}$. A computer program related to process of diagnostic, therapeutic and surgical methods for the treatment of humans or animals may be excluded from patentability ${ }^{228}$. The most important point is to be considered here that the grant of an IP right does not prevent the possibility for the governments to regulate production and the use and distribution of products on any public policy grounds, such as concerns about public order, morality, health or environment ${ }^{229}$.

The TRIPS Agreement provides a fair amount of flexibility to Member Countries to adjust the level of protection by providing limitations and exceptions to exclusive rights ${ }^{230}$. In addition, the Agreement and the Conventions incorporated in it allow for numerous specific limitations and contain provisions on compulsory licenses.

An important part of IP policy as the Secretariat of the WTO described is that governments take appropriate measures in other areas of economic and social policy that enable the society to benefit for the IP system and to prevent its abuse. Article 8 of the TRIPS Agreement, entitled "Principles", recognizes that "Members, may, in formulating or amending their laws and regulations, adopt measures necessary to protect public health and nutrition, and to promote the public interest in sectors of vital importance to their socio-economic and technological development, provided that such measures are consistent with the provisions of this Agreement." The Agreement explained the proviso to the paragraph in paragraph 2 that the proviso may be needed to prevent the abuse of intellectual property rights by right holders or the resort to practices, which unreasonably restrain trade or adversely affect the international transfer of technology ${ }^{231}$.

There are arguments that the patent system could be detrimental to: scientific progress and access to its benefit, realizing the right to cultural participation,

\footnotetext{
225 See Article 9 paragraph 2 of the TRIPS Agreement.

${ }^{226}$ See Article 27 paragraph 1 of the TRIPS Agreement.

${ }^{227}$ See Article 27 paragraph 2 of the TRIPS Agreement.

${ }^{228}$ See Protection of Intellectual Property Under the TRIPS Agreement, Secretariat of the World Trade Organization, available at www.wto.org, last visited 9 August 2004.

${ }^{229}$ This is categorically stated in Article 17 of the Berne Convention, which has been incorporated into the TRIPS Agreement.

${ }^{230}$ See Article 13, 17, 26.2 and 30 of the TRIPS Agreement.

${ }^{231}$ See Protection of Intellectual Property Under the TRIPS Agreement, Secretariat of the World Trade Organization, available at www.wto.org, last visited 9 August 2004.
} 
right to health, right to food etc $^{232}$. But there is no apparent opposition of human rights activists to the measures described in the previous chapters for curbing software piracy in eCommerc.

\subsection{Human Rights Approach in Curbing Measures}

The constitutionality of the Digital Millennium Copy Right Act of the USA has been tested in Universal City Studios, Inc, v. Corley and the court upheld the constitutionality of the DMCA. Moreover the Court held that injunction, which prevented Internet web sited owners from providing hyperlinks to other web sites that posted decryption code, was unrelated to suppression of free expression. ${ }^{233} \mathrm{In}$ this case the U.S. Court of Appeals upheld the copyright owners right to use the encryption codes to bar access to copyright materials and found that fair use did not guarantee access to such materials in order to copy it by the optimum method or in the identical format. ${ }^{234}$ Therefore, it can be inferred that the digital rights management is not opposed to the right to freedom of expression. It is also argued that technical protection measures only apply in the digital environment, and in particular, to works made available in digital form on-line over the Internet. The public will still be able to have access to works on paper, to make analogue copies of sound and audiovisual recordings and so on. Protection measures aim at securing the public interest in making information available to the public but do not guarantee the public the possibility of making private copies of the highest possible quality. WIPO Internet Treaties were designed to encourage the development of technical protection devices and rights management systems. The preamble to both the Treaties address the need to introduce new international rules and clarify the interpretation of certain existing rules in order to provide adequate solutions to the questions raised by new economic, social, cultural and technological developments. The Preamble of both the Treaties also recognize the need to maintain a balance between the rights of copyright and related rights owners and the larger public interest, referring, in particular, to education, research and access to information.

The right to development is recognized as human rights. ${ }^{235}$ Article 1 of the Declaration on the Right to Development mentions that the right to development is an inalienable human right by virtue of which every human person and all peoples are entitled to participate in, contribute to, and enjoy economic, social, cultural and political development, in which all human rights and fundamental freedoms can be fully realized.

The IIPA 2362002 Report confirms the important role of copyright-based industries which represent one of the fastest-growing sectors of the economy,

\footnotetext{
${ }^{232}$ See Dr. Audrey R. Chapman, Discussion paper on “ Approaching Intellectual Property as a Human Right: Obligation Related to Article 15 (1) (C), Published by United Nations Economic and Social Council, E/C.12/ 2000/12, 3 October 2000.

${ }^{233}$ See ibid P. 28.

${ }^{234}$ See Gillian Davies, Copyright And the Public Interest, P. 309. Second Edition, Sweet \& Maxwell, 2002.

${ }^{235}$ First recognized by the UN Commission on Human Rights in 1977, Declaration on the Right to Development adopted by the General Assembly in 1986.

${ }^{236}$ The International Intellectual Property Alliance (IIPA).
} 
making significant contributions to domestic employment and revenue growth as well as to international trade. The Report states that in both developed and developing countries, studies have generally reported contributions to GDP in the range of 3 to 6 per cent. ${ }^{237}$

The Internet created a huge demand for content and an opportunity of its production, which has not been fully explored by the developing countries. The implementation of copyright laws, modernized by the WIPO Internet Treaties enable these countries to go for the creative development and ensure the protection of such development. A 'digital divide' now exists between technologically developed and developing countries, as well as between populations within countries, and between genders and age groups worldwide. ${ }^{238}$ The G8 Digital Opportunity Task Force (DOT Force), described the phenomenon as follows:

"This 'digital divide' is, in effect, a reflection of existing broader socio-economic inequalities and can be characterized by insufficient infrastructure, high cost of access, inappropriate or weak policy regimes, inefficiencies in the provision of telecommunication networks and services, lack of locally created content, and uneven ability to derive economic and social benefits from information-intensive activities. $" 239$

The United Nations Secretary General, Kofi Annan, stated about building 'digital bridges' to enable the socio-economic development of billions of people throughout the world who are not connected to the digital technologies and their potential benefits. ${ }^{240}$

How effective application of IP law can narrow down the digital divide can be perceived from the following statement:

"The intellectual property system is a tool that may be used to narrow the digital divide. National policies and legal systems that include up-to-date intellectual property laws can support foreign and local investment and encourage the

\footnotetext{
${ }^{237}$ See E-Commerce and Development Report 2002, P.173, United Nations Conference on Trade and Development, available at ro.unctad.org/ecommerce/ecommerce_ew/edr02_en.htm, last visited 24 August 2004.

${ }^{238}$ For a general discussion of the digital divide, see the presentation of J. O. Okpaku, Sr., President and CEO, Telecom Africa Corporation, Second WIPO E-Commerce Conference (September 2001).

${ }^{239}$ See Report of the Digital Opportunity Task Force (DOT Force), "Digital Opportunities for All: Meeting the Challenge," (May 11, 2001), at p.6, available at http://www.dotforce.org/reports/DOT_Force_Report_V_5.0h.html. The DOT Force was created by the G8 Heads of State at their Kyushu-Okinawa Summit, July 2000, and comprised 43 teams from government, private sector, non-profit organizations and international organizations, representing developed and developing countries.

240 Message of United Nations Secretary-General Kofi Annan to the meeting of the Internet Corporation for Assigned Names and Numbers (ICANN), in Accra, Ghana, March 10 to 14, 2002. See also the Report of the UN ICT Task Force Meeting "Digital Bridge to Africa: The Launch of the Digital Diaspora Network - Africa," (DDN-A), New York (July 12, 2002).
} 
creation of local content that enables the population to derive economic as well as social benefits from their creative endeavors." 241

Software piracy becomes an obstruction on the way of building digital bridge between developed and developing countries. The countries where the rate of piracy is high are in maximum cases over populated and having low per capita GDP. India and Pakistan and China could be the best example of these kinds of countries. ${ }^{242}$ In the United States Piracy rate has been reduced to $25 \%$ in 1999 from $48 \%$ in $1989 .{ }^{243}$ This reduction in piracy rate indicates that where people have got easy access to information technology system and the Internet, in such a country piracy rate is comparatively low. The United Kingdom can be another example of low software piracy rate. ${ }^{244}$ Therefore, the economic growth of a country, implementation of IP law and reduction of piracy rate are interrelated.

The Internet and its related information technology (IT) were invented and developed in North America and Europe, but have been virtually taken up by every country in the world. ${ }^{245}$ Due to the Internet and eCommerce the participation of the people in contributing and enjoying economic development has been increased considerably. In order to boost such participation the protection of IPRs in eCommerce transaction, especially protection of software is extremely important. If we can protect software infringements through implementation of IP law then people would be able to contribute much economic development through the Internet and eCommerce. Such a contribution would be definitely helpful to achieve the right to development.

\footnotetext{
${ }^{241}$ See Intellectual Property On the Internet: A Survey Issues,P. 150-151, WIPO/INT/02, December 2002, available at ecommerce.wipo.int, last visited 23 August 2004.

${ }^{242}$ See Copyright Industries Release Report on Piracy In 56 Countries and Press their Global Trade Priorities for 2004, IIPA, available at www.iipa.com, last visited 25 August 2004.

${ }^{243}$ See SIIA'S Report on Global Software Piracy 2000, available at www.siia.net, last visited 25 August 2004.

${ }^{24} 426 \%$ Ibid.

${ }^{245}$ See Intellectual Property On the Internet: A Survey Issues,P. 148, WIPO/INT/02, December 2002, available at ecommerce.wipo.int, last visited 23 August 2004.
} 


\section{Conclusion and Recommendations}

The placing of order, payment and delivery can take place on line in case of software. The core importance of software in eCommerce lies here. This raises the immense prospect of software transaction in eCommerce. At the same time software can be infringed in multiple ways with grave intensity in the borderless world of eCommerce within the shortest possible time. Jon O. Newman, Circuit Judge of U.S.A perfectly figured out this situation in his judgment in Universal City Studios, Inc. v. Corley ${ }^{246}$ by stating

\footnotetext{
"In principle, the digital world is very different. Once a decryption program like DeCSS is written, it quickly can be sent all over the world. Every recipient is capable not only of decrypting and perfectly copying plaintiffs' copyrighted DVDs, but also of retransmitting perfect copies of DeCSS and thus enabling every recipient to do the same. They likewise are capable of transmitting perfect copies of the decrypted DVD. The process potentially is exponential rather than linear."
}

Still now software gets protection mainly from copyright law. TRIPS Agreement makes it obligatory upon contracting parties to grant copyright protection to computer programs. Software also can get protection through patent law subject to fulfilling certain condition like having related to machine or process or having a technical effect. Trade secret law also grants certain protection to software.

Strong intellectual property protection for software is an important part of any nation's economic growth and development. Empirical and anecdotal evidence clearly show the enormous economic and social benefits of a legitimate, thriving software industry whatever software is effectively protected by a nation's laws and law enforcement agencies. Despite obvious economic and social benefits, the development, distribution and marketing of domestically produced software remains confined to a small group of nations. This is due in large part to the failure of many nations to encourage their residents, entrepreneurs and businesses to develop, distribute and market software through enactment and enforcement of strong intellectual property protections for computer software.

Strong intellectual property protection has numerous benefits. It:

- Encourages individuals and businesses to create innovative software applications and

improve upon existing applications.

- Encourages an indigenous software industry that can tailor products to local conditions.

- Ensures new ideas and technologies are widely distributed.

- Promotes value and investment in the national economy.

- Encourages technology transfers between nations.

246273 F.3d 429 (2nd Cir. 2001). 
Strong copyright protection is extremely important for computer software in less-industrialized countries. The software industry is one area where local businesses can compete effectively with multinationals in both local and foreign markets. Massive capital investment is not necessary nor is acquisition of expensive foreign technology. In fact, local entrepreneurs often know the local needs and markets better than the multinationals and can exploit that knowledge. However, without adequate copyright and other protection, those local companies that create valuable software will soon find that others will copy their programs without permission and without remuneration, thereby decreasing their incentives to create and market new programs ${ }^{247}$.

In order to protect software from being infringed or pirated WIPO Member States can adopt the following steps:

(i) Use only legal software in government agencies and State-owned enterprises,

(ii) Budget the funds needed to license legal software and

(iii) Stay legal by implementing accountable software asset management practices.

(iv) Make effective enforcement efforts against all forms of software piracy a reality by complying with the obligations of the TRIPS Agreement.

(v) Ensure that computer software is no less protected on the Internet than on the street by promptly joining the WIPO Copyright Treaty, enacting legislation to meet the treaty's obligations and effectively enforcing those laws without undue delay. $^{248}$

To fight software piracy it could be effective to use Certified Software Manager (CSM), Software Asset Training Program that are now available in the United States, Canada, China, Hong Kong, Singapore, Australia and New Zealand.

Liability of intermediaries like ISPs, BBS should be established by introducing measures like $\mathrm{NTD}^{249}$ It can be effective at closing down sites that infringe copyright, but a site closed down by one ISP can reappear within hours on another server hosted by a different ISP. To combat this, rights holders have asked ISPs to disclose customer identities so that criminal charges can be pressed against persistent offenders. DMCA establishes a procedure by which a copyright owner can obtain a subpoena from a federal court ordering a service provider to disclose the identity of a subscriber who is allegedly engaging in infringing activities $^{250}$. Such a procedure might be effective in combating Internet piracy like auction site piracy, FTP Sites, Warez, P 2 P etc.

\footnotetext{
${ }^{247}$ See SIIA's Report on Global Software Piracy 2000, available at www.siia.net, last visited 10 August 2004.

248 See Ibid.

249 NTD (Notice and Take down) is a measure, where rights holders finding unauthorized works online ask the content provider's ISP (internet service provider) to have the material removed, or links to it deleted. See Section 512(g)(1)) of DMCA and e-commerce Directive (00/31/EC).
}

${ }^{250}$ Section 512(h). 
Intermediaries should be held liable for contributory copyright infringements when intervening conduct on the part of intermediaries is found. National legislatures should explicitly provide such provision in the copyright law. ${ }^{251}$

WIPO can take initiative to fix the liability of intermediaries by encouraging Member States to enter into a treaty like WCT.

After shutting down Napster, Kazaa BV, Grokster/ Streamcast introduced a new way of file sharing ${ }^{252}$ to defeat the ruling set in the Napster case. The court opined that if either defendant closed their doors and deactivated all computers within their control, users of their products could continue sharing files with little or no interruption. So in order to justify a judicial remedy in such cases it is necessary to expand the copyright law beyond its existing well-known boundaries. So it is the national legislature, which can come up with necessary copyright law amendment to solve the new problems created by Kazaa BV, Grokster ${ }^{253}$ etc in introducing a new way of file sharing.

The Member States of WIPO should introduce appropriate Rights Management Information $^{254}$ as has been introduced by the USA ${ }^{255}$ and EC Countries ${ }^{256}$. Member States should provide in their respective national legislation appropriate protection measure for $\mathrm{CMI}^{257}$ with specific exception like law enforcement, intelligence and other government activities.

In order to achieve a sound balance between human rights and incentive to the IP right holders in software, the world community could come up with an appropriate revision plan of the TRIPS Agreement, the WIPO Copyright Treaty, the Berne Convention and the Paris Convention to provide maximum limit of IP right protection for software in these international IP treaties. Moreover the State governments and United Nations bodies could implement the following specific recommendations mentioned in the recent Sub-Commission's resolution on "Intellectual Property and Human Rights"258:

(2) Governments should protect the social functions of intellectual property in accordance with international human rights obligations and principles. One way to do so would be to have a mechanism for a human rights review/appeal of decisions by patent and copyright procedures.

(3) Inter-governmental organizations should integrate international human rights obligations and principles into their policies, and practices, and operations.

(4) The WTO in general and the Council on TRIPS more specifically should take fully into account existing State obligations under international human rights instruments during its ongoing review

\footnotetext{
${ }^{251}$ See the minority view in Religious Technology Center v. Netcom On-line at p. 63.

${ }^{252}$ See Ibid P. 27.

${ }^{253}$ See P 26 for details.

${ }^{254}$ Article 12 of WCT.

${ }^{255}$ Section 1202 of DMCA.

${ }^{256}$ Article 7 of EC Copyright Directive.

${ }^{257}$ Copyright Management Information (CMI). See section 1202 of DMCA.

258 "Intellectual Property Rights and Human Rights", Sub-Commission on the Promotion and Protection of Human Rights, August 17,2000.
} 
of the TRIPS Agreement. For this to happen in a meaningful way, however, it would first be necessary to gain recognition for the principle that human rights are fundamental and prior to free trade itself. Two experts have recently proposed that the interpretation of the primacy of human rights over trade liberalization is consistent with the trade regime on its own terms ${ }^{259}$.

(5) The Special Rapporteurs on Globalization and its impact on the full enjoyment of human rights should include consideration of the human rights impact of the implementation of the TRIPS Agreement in their next report. The United Nations High Commissioner for Human Rights should undertake an analysis of the human rights impacts of the TRIPS Agreement.

(6) WIPO, WHO, UNDP and UNEP should continue and deepen their analysis of the impacts of the TRIPS Agreement, including a consideration of its human rights implications.

(7) The Committee on Economic, Social and Cultural Rights should clarify the relationship between intellectual property rights and human rights, including through the drafting of a general comment on this subject.

In respect of balancing between human rights and IPRs the comment made by the WTO Secretariat is remarkable and would be a guide for the WIPO Member States. The Comment is as follows:

"An optimal balance within IP system at the national or multinational level can be reached by properly determining the definition of protectable subject- matter, scope of rights, permissible limitations and term of protection. This balance is constantly developing both at the national and international level in response to economic and technological as well as political developments." 260

There is no evidence that software piracy will be eliminated anytime in the foreseeable future. Many countries have made efforts to improve intellectual property protection in computer software. However, the high rates of software piracy and dramatic losses to software developers through out the world demonstrate that much remains to be done. There is evidence that continuing education and enforcement efforts can - and do make a difference. In the United States, for example, the level of piracy has been reduced from 48 percent in 1989 to 25 percent in 1999. Thus, we have learned that decreasing software piracy rates requires the combined efforts of policy-makers, software developers and publishers, businesses, journalists and individuals. As long as software piracy remains, there will be fewer jobs, less research and development, increased costs and lower standards of living ${ }^{261}$.

\footnotetext{
${ }^{259}$ See Robert Howse and Makau Mutua, "Protecting Human Rights in Global Economy: Challenges for the World Trade Organization", Montreal: Rights \& Democracy, International Center for Human Rights and Democratic Development, 2000.

${ }^{260}$ See Protection of Intellectual Property Under the TRIPS Agreement, Secretariat of the World Trade Organization, available at www.wto.org, last visited 9 August 2004.

${ }^{261}$ See Ibid F.N.247.
} 


\section{Bibliography}

\section{BOOKS \& ARTICLES}

A.E. Carroll, 'A Review of Recent Decisions of the United States Court of Appeals for the Federal Circuit: Comment: Biotechnology and the Global Impact of U.S. Patent Law: Not Always the Best Medicine', The American University Law Review 1995.

AR Chapman, 'A Human Rights Perspective on Intellectual Property, Scientific Progress, and Access to the Benefits of Science P138, Intellectual Property and Human Rights, A Panel Discussion to commemorate the $50^{\text {th }}$ Anniversary of the Universal Declaration of Human Rights, WIPO Publication No. 762(E), WIPO 1999.

Bainbridge D., Intellectual Property, $4^{\text {th }}$ Ed., Financial Times Pitman Publishing, 1999.

Bainbridge D., Introduction to Computer Law, Fifth Edition, Longman, 2004.

Cornish \& D Llewelyn, Intellectual Property: Patents, Copyright, Trademarks and Allied Rights, $5^{\text {th }}$ Ed., Sweet and Maxwell, 2003.

Dr. Matthew Lee, 'Patentability of Software-Related Inventions', available at www.is.cityu.edu.hk/Research/workingpapers/paper/9420.pdf, last visited 28 August 2004.

Dr. Peter Darhos, 'The Universality of Intellectual Property Rights: Origins and Developments, Intellectual Property and Human Rights, A Panel Discussion to Commemorate the $50^{\text {th }}$ Anniversary of the Universal Declaration of Human Rights, WIPO Publication NO. 762 (E), WIPO 1999.

Dr. Silke von Lewinski Head of Department, Max Planck Institute (Munich, Germany ) 'INTELLECTUAL PROPERTY, NATIONALITY, AND NONDISCRIMINATION'

www.wipo.org/tk/en/activities/ 1998/humanrights/papers/pdf/lewinski.pdf , last visited 22 August 2004.

Gillian Davies, Copyright and the Public Interest, Sweet \& Maxwell, 2002.

GRAIN, "TRIPs-Plus" Through the Back Door: How Bilateral Treaties Impose Much Strong Rules for IPRs on Life than the WTO (July 2001), available at www.grain.org/briefings/?id $=6$, last visited 22 August 2004.

HL Macqueen, 'Copyright and the Internet', Law \& the Internet.Com/ a Framework for electronic Commerce, Edited by Lilian Edwards \& Charlotte Waelde, Hart Publishing 2000.

Joon Kook Park, 'Asian Protection Strategies for the Internet', Intellectual Property for the Internet, Edited by LC Lee and JS Davidson, A Panel Publication, 1997.

James Catchpole, 'The Regulation of Electronic Commerce: A Comparative Analysis of the Issues Surrounding the Principles of Establishment, International Journal of Law and Information Technology, Vol. 9 No. 1, Oxford University Press 2001.

JS Pascual and RG Fernandez, 'Software Patents and their Impact in Europe', available at http:// joel.editthipage.com/stories/story, last visited 9 July 2004. 
Laurence Jacobs, 'Demystifying Copyright Infringement of Computer Software [1994] 5 EIPR 206', Readings In Intellectual Property, Edited by Alison Firth et al., Sweet \& Maxwell 1998.

Paul Tija, 'The Software Industry In Bangladesh and its Links to the Netherlands', The Electronic Journal on Information Systems In Developing Countries, EJISDC (2003) 13, 5, 1-8, available at www.ejisdc.org, last visited 9 August 2004.

Professor Laurence Helfer, 'Human Rights and Intellectual Property: Conflict or Co-existence?, available at http://ssrn.com/abstract=459120, last visited 1 August 2004.

Rochelle Cooper Dreyfuss \& Andreas F. Lowenfeld, 'Two Achievements of the Uruguay Round: Putting TRIPS and Dispute Settlement Together, 37 Va.J.Int'l L. 275, 295-304 (1997).

Robert Howse and Makau Mutua, 'Protecting Human Rights in Global Economy: Challenges for the World Trade Organization', Montreal: Rights and Democracy, International Center for Human Rights and Democracy Development, 2000.

Wend Wendland, 'Intellectual Property and Human Rights Working Draft', United Nations Committee on Economic, Social and Cultural Rights, Geneva, November 27, 2000.

\section{International Treaties and Conventions}

Agreement on Trade-Related Aspects of Intellectual Property Rights (TRIPS Agreement) (1994)

International Covenant on Economic, Social and Cultural Rights (Adopted and opened for signature, ratification and accession by General Assembly resolution 2200 A (XXI) of 16 December 1966)

International Covenant on Civil and Political Rights (Adopted and opened for signature, ratification and accession by General Assembly resolution $2200 \mathrm{~A}$ (XXI) of 16 December 1966)

The Berne Convention for the Protection of Literary and Artistic Works (1971)

The International Convention for the Protection of Performers, Producers of Phonograms and Broadcasting Organizations (the Rome Convention) (1961)

The Paris Convention for the Protection of Industrial Property (1967)

The Patent Cooperation Treaty (PCT) (1970)

Universal Declaration of Human Rights (Adopted and proclaimed by General Assembly resolution 217 A (III) of 10 December 1948)

WIPO Copyright Treaty (WCT) (1996)

WIPO Performances and Phonograms Treaty (WPPT) (1996)

\section{WIPO Documents}

Mr. Jeffrey at el., 'Current Developments in the Field of Digital Rights Management', Standing Committee on Copyright and Related Rights, Tenth Session, Geneva, November 3 to 5, 2003.

Primer on Electronic Commerce and Intellectual Property Issues, WIPO, May 2000, available at http://ecommerce.wipo.int/primer/, last visited 22 August 2004. Intellectual Property A Power Tool for Economic Growth, available at www.wipo.int/about/wipo/en/dgo/wipopub888/index.wipo.pub888.html, last visited 8 June 2004. 
Intellectual Property and Human Rights, A Panel Discussion to Commemorate the $50^{\text {th }}$ Anniversary of the Universal Declaration of Human Rights, WIPO Publication NO. 762 (E), WIPO 1999.

Intellectual Property On the Internet: A Survey Issues, WIPO/INT/02, December 2002, available at ecommerce.wipo.int., last visited 23 August 2004.

\section{Document of International Institutions}

Intellectual Property Rights and Human Rights, Res. 2000/7, E/CN. 4/Sub/2/2000/L.20, Sub-Commission on the Protection of Human Rights.

Intellectual Property and Human Rights: Report of the Secretary General, ESCOR, Sub-Commission on the Promotion and Protection of Human Rights, $52^{\text {nd }}$ Session, Provisional Agenda Item 4, U.N. Doc. E/CN.4/Sub.2/2001/12(2001).

World Health Organization, Globalization, TRIPS and Access to Pharmaceuticals, WHO Policy Perspectives on Medicines, No. 3, WHO/EDM/2001.2 at 5 (March 2001).

Report of the United Nations High Commissioner for Human Rights, The Impact of the Agreement on Trade-Related Aspects of Intellectual Property Rights on Human Rights, E/CN.4/Sub.2/2001/13, 11-12 (June 27 2001).

E-Commerce and Development Report 2002, P.173, United Nations Conference on Trade and Development, available at ro.unctad.org/ecommerce/ecommerce_ew/edr02_en.htm, last visited 24 August 2004.

\section{Documents of National Governments}

Copyright, Designs and Patents Act of 1988 of the United Kingdom Copyright Act of 1976 of the U.S.A, Title 17 of U.S.C.

Computer Program Protection Act of 1987 of the Republic of Korea

Digital Millennium Copyright Act of 1998 of the U.S.A.

Cracking Down on Cpycats: Enforcement o Copyright in Australia, The

Parliament of the Commonwealth of Australia, House of Representatives,

Standing Committee on Legal and Constitutional Affairs.

\section{Documents of N.G.OS}

Copyright Industries Release Report on Piracy In 56 Countries and Press their Global Trade Priorities for 2004, International Intellectual Property Alliance (IIPA), available at www.iipa.com, last visited 25 August 2004.

Doesn't Everybody Do It? Internet Piracy Attitude and Behaviours, A Report on a Survey conducted by the Software and Information Industry Association and KPMG LLP( An Accounting and Tax Firm)-Fall 2001, available at www.siia.net, last visited 10 August 2004.

IPI 200: The Economic Impact of Patentability of Computer Programs, available at swpat.ffii.org, last visited 25 August 2004.

Software and Information Industry Association's Report on Global Software Piracy 2000, available at www.siia.net, last visited 10 August 2004. 


\section{Relevant Web Sites}

www.wipo.int, last visited 24 August 2004.

www.unctad.org, last visited 16 May 2004.

www.wto.org, last visited 9 August 2004.

www.parliament.uk/post/home.htm, last visited 30 May 2004.

www.siia.net, last visited 10 August 2004.

www.bitlaw.com, last visited 10 July 2004.

Swpat.ffii.org last visited 25 August 2004.

www.hmso.gov.uk/acts/ukpga19880048en3.htm, last visited 22 July 2004.

www.ejisdc.org, last visited 9 August 2004. 


\section{Table of Cases}

A \& M Records, Inc. v. Napster, Inc., 114 Supp.2d 896 (N.D. Cal.2000).

Coster Group v. Loopnet, 373, F. 3d 544.

City Studios, Inc. v. Reimerdes, 82 F.Supp.2d 211 (S.D.N.Y 2000).

Diamond v. Diehr, 101 S.ct. 1048 (1981).

Gottschalk v. Benson, 409 U.S. 63 (1972).

Hyde Park Residence Ltd. V Yelland (Hyde Park), [2001] Ch.143.

Ibcos Computers v Barclays Mercantile, [1994] F.S.R. 275.

IBM / Semantics, T 52/85 [1984] 8 EPOR 454.

IBM/ Network, T 6/83, [1990] EPOR 91.

Itar-Tass Russian News Agency v. Russian Kurier, Inc., 153 F.3d 82, 47 U.S.P.Q. 2d 1810.

MAI Sys., Corp. v. Peak Computer, Inc., 991 F.2d 511 ( $9^{\text {th }}$ Cir. 1993).

Metro-Goldwyn-Mayer Studios, Inc. v. Grokster, 259 F. Supp.2d 1029 (C.D. Cal. 2003).

Playboy Enterprises Inc. v. Frena 839 F.Supp.1552 (M.D. Fla. 1993).

Pro Sieben Media AG v Carlton UK Television Ltd., [1999] 1 WLR 605

Re Alappat, 33 F. 3d 1526, 31 U.S.P.Q. 2d 1545 (Fed. Cir. 1994).

Religious Technology Center v. Netcom On-Line, 907 F.Supp.1361.

Re Schrader, 22 F. 3d 290, 30 U.S.P.Q. 2d 1455 (Fed. Cir. 1994).

Re Lowry, 32 U.S.P.Q. 2d 1031 (Fed. Cir. 1994).

Re Warmerdam, 33 F. 3d 1354, 31 U.S.P.Q. 2d 1754 (Fed. Cir. 1994).

Re Trovato, 33 U.S.P.Q. 2d 1194 (Fed. Cir. 1994).

Sony Corp. v. Universal City Studios, 464 U.S. 417 (1984).

Sony Compute Entertainment v. Owen, [2002] EWHC 62.

Sony Music Entertainment (UK) Ltd v Easyinternetcafe Ltd, [2003] EWHC 62.

Universal City Studios, Inc. v. Corley, 273 F.3d 429 ( $2^{\text {nd }}$ Cir.2001).

United States of America v. Elcom, Ltd. 203 F.Supp.2d 1111 (N.D.Cal. 2002).

Vicom, T 208/84, [1987] 2 EPOR 74. 
